Daniele Gentile Cardoso

Variabilidade Praial nas Praias do Lázaro, Domingas

Dias e Sununga, Litoral Norte de São Paulo Frente à

Passagem dos Sistemas Frontais (Ubatuba, SP).

Dissertação apresentada ao Instituto

Oceanográfico da Universidade de São

Paulo, como parte dos requisitos para

obtenção do título de Mestre em

Ciências, área de Oceanografia

Geológica

Orientador: Prof. Dr. Moysés Gonsalez

Tessler

São Paulo

2013 


$$
\begin{gathered}
\text { Universidade de São Paulo } \\
\text { Instituto oceanográfico }
\end{gathered}
$$

\section{Variabilidade Praial nas Praias do Lázaro, Domingas Dias e \\ Sununga, Litoral Norte de São Paulo Frente à Passagem dos \\ Sistemas Frontais (Ubatuba, SP).}

\section{(CORRIGIDA)}

Dissertação apresentada ao Instituto Oceanográfico da Universidade de São Paulo, como parte dos requisitos para obtenção do título de Mestre em Ciências, área de Oceanografia Geológica

Julgada em

$\operatorname{Prof}(\mathrm{a}) . \operatorname{Dr}(\mathrm{a})$.

Conceito

$\operatorname{Prof}(a) . \operatorname{Dr}(a)$.

Conceito

$\operatorname{Prof}(\mathrm{a}) . \operatorname{Dr}(\mathrm{a})$.

Conceito 
Dedico esse trabalho ao meu pai, Marcus Vinicius Taveira Cardoso, por me apoiar, me ajudar, rir e chorar comigo durante esse período. Sem você talvez esse trabalho não chegasse ao fim. 


\section{Agradecimentos}

Essa é hora em que aliviados, sabemos que chegamos quase ao fim, e é impossível acreditar que isso tudo ficou pronto sozinha. Esse trabalho como tudo na minha vida foi construído com muitas mãos, consolos, conhecimentos e aprendizados que são e sempre serão fundamentais na minha vida.

Agradeço ao meu orientador, Prof. Dr. Moyses Tessler, que foi muito mais que isso ao longo desse tempo. Obrigada por ter tanta paciência comigo, por acreditar em mim até quando muitas vezes eu não acreditei e ser muito mais que um orientador, sendo pai e amigo. Você é um exemplo pra mim e minha gratidão não cabe em palavras.

Pai, você sabe o quanto foi importante pra eu chegar até aqui, obrigada por ter ficado do meu lado, me dando força e esperança e me fazendo acreditar que eu ia conseguir, eu amo você.

Mãe, Obrigada por tudo, você sempre me acalmando e me mostrando o lado bom das coisas, você é um espelho, eu amo você.

À toda minha família, que cada um de seu modo, me orgulham e me apóiam em tudo, me ajudando nessa e em todas as trilhas que já segui, vocês são minha base, minha força, minha inspiração.

À todos do IOUSP que sempre me ajudaram, nos corredores e no campo, levo mais que colegas profissionais, levo amigos também, obrigado Diana Italiani (Di), Janaina Camargo (Jana), Mariana Santos (Mari), Fernando Ferreira (Fernandão), Paulo Souza (PH), Filipe Galiforni (Creu), Nery Conti, Juliana Santos (Ju), Edilson Faria (Edi), Carlos Rogacheski (Roga), Clarissa de Luca, entre outros.

Eduardo Garcia (Duuuuu), Obrigada por tudo amigo, pela ajuda nos meus momentos mais desesperados de campo e na vida, pela companhia, amizade e por me fazer manter a calma e ver que o mundo não ia acabar toda vez que achava que ia.

Marcelo Gagliardi (Neco) obrigado pela paciência que você sempre teve de me ensinar tudo aquilo que eu não sabia, com calma e paciência. MUITO OBRIGADA. 
À Dr. Samara Cazzoli (Sa), Obrigada pelo carinho, pela paciência, amizade, enfim por tudo desde a minha base, você me ajudou a entrar e a sair desse mestrado, me espelho em você, Obrigada!

À todos da biblioteca, pela atenção, sempre tão prestativos e dispostos a me ajudar com muito carinho e atenção. Em especial ao Wagner por ter revisado minhas referências e arrumado a minha bagunça, Obrigada!

À todos da Base Norte do Instituto Oceanográfico, me tratando e me recebendo com tanto carinho, em especial ao Airton, que sempre estava disposto a me ajudar e me salvar por tantas vezes e a Fátima, dando um jeitinho pra ajustar as minhas datas com tanta paciência.

À todos da equipe de transporte do IOUSP, pela atenção.

À Coordenação de Aperfeiçoamento de Pessoal de Nível Superior (CAPES) pelo financiamento desta pesquisa através de bolsa de mestrado.

Obrigada Dr. Eduardo Siegle, pelas orientações, dicas, atenção, compreensão e principalmente pela disponibilização do equipamento.

Aos amigos que me ajudaram no Inglês e nas imagens, Carol, Gu, Tia Claudia e Rô.

E finalmente a Deus, ao universo e a toda e qualquer força que me acompanha, me dando sempre tudo de melhor, que eu sei que continuará me dando.

Tenho certeza que saio daqui diferente do que entrei e que esse é apenas o começo de um grande final. Muito Obrigada!!!!!!!!!!!!!!!!!

Tenha fé, Vá na fé, Nunca perca a fé em Deus. 
"Quero um dia conhecer pessoalmente, tudo aquilo que já estudei nos livros" (Frase que ouvi do meu orientador Moyses Tessler) 


\section{RESUMO}

O presente trabalho propõe caracterizar a variabilidade espaço temporal dos prismas praias das praias do Lázaro, Domingas Dias e Sununga em relação às variáveis meteorológicas e oceanográficas, condicionadas pela passagem dos sistemas frontais, proporcionando à compreensão da evolução morfológica deste segmento costeiro da Enseada da Fortaleza e facilitar os próximos estudos para outras enseadas do litoral Norte do Estado de São Paulo. Para a caracterização morfodinâmica da face praial das praias da Sununga, Lázaro e Domingas Dias, no município de Ubatuba, São Paulo, foi utilizado o método de caminhamento com o uso de equipamento de precisão em posicionamento geográfico (DGPS), análises meteorológicas, análises granulométricas e modelo de padrão de incidência de ondas. Os principais resultados encontrados colaboraram para concluir que as praias do Lázaro, Domingas Dias e Sununga, embora estejam inseridas na mesma enseada, e possuam as mesmas características geológicas, meteorológicas e oceanográficas, se comportam de maneiras distintas frente aos processos dinâmicos de ondas geradas nos sistemas frontais, e nos sistemas de "tempo bom", devido ao nível de exposição a que ficam submetidos seus arcos praiais a incidência de ondas provenientes de distintas direções. O acompanhamento espaço temporal das três praias da enseada da Fortaleza, todas com suas faces praiais voltadas rumo aos quadrantes a sul, sob as mesmas condicionantes de origem climática, geológica, oceanográfica e antrópica, evidenciaram que a intensidade dos processos de perda e recuperação sedimentar destas praias não dependem apenas do grau de proteção, ou exposição, destes ambientes a ação mais direta das ondas mais esbeltas, mais energéticas, mas também da possibilidade de remobilização de sedimentos dentro do próprio prisma praial.

Palavras - Chave: Enseada da Fortaleza, morfodinâmica costeira, litoral norte do estado de São Paulo, Ubatuba, DGPS. 


\begin{abstract}
The purpose of this research is to characterize the spatio-temporal variability of Lázaro, Domingas Dias and Sununga's beaches, in Ubatuba, São Paulo, in relation to oceanographic and meteorological variables, conditional on the passage of frontal systems, to provide the understanding of the morphology evolution of this coastal segment of Fortaleza Bay, and to facilitate future studies on other bays of the northern coast of São Paulo. To characterize the morphodynamics of those beaches, we used the method of beach profile with precision equipment in geographical positioning (DGPS), meteorological and gain-size analyses and coastal modeling system (SMC). The main results collaborated to the conclusion that, although these beaches are inserted in the same cove and have the same geological, meteorological and oceanographic characteristics, they behave differently when compared to the dynamic processes of waves generated in frontal systems, and the "good weather" systems, due to the level of exposure of their bows beaches to waves originated from different directions, showing that the intensity of the loss and recovery of these sedimentary beaches not only depend on the degree of protection or exposure of these environments to the more direct action of more slender and more energy waves, but also on the possibility of remobilization of sediments inside the own praial prism.
\end{abstract}

Keywords: Fortaleza Bay, coast morphodynamics, northern coast of São Paulo, Ubatuba, DGPS. 


\section{Lista de Figuras}

Figura 1- Mapa de localização da área de estudo (adaptado de Andrade, 2002)

Figura 2 Foto aérea das praias estudas e dos trechos amostrados. 27

Figura 3 Os quatros padrões sinópticos de eventos eventos de velocidade do vento: (A) Padrão I, (B) Padrão II, (C) Padrão III, (D) Padrão IV (Calliari, 2012)

Figura 4 Formação quaternária do litoral Norte Paulista (Suguio e Martin, 1978)

Figura 5 Foto das áreas amostradas (Google Earth). 39

Figura 6 Gráfico das precipitações em junho de 2012 na cidade de Ubatuba-SP (IOUSP/Base Norte,2012).

Figura 7 Gráfico das precipitações no mês de Julho de 2012 para a cidade de Ubatuba -SP (IOUSP/Base Norte,2012).

Figura 8 Gráfico das precipitações no mês de Agosto de 2012 para a cidade de Ubatuba -SP (IOUSP/Base Norte,2012). 47

Figura 9 Gráfico da pressão atmosférica durante os meses estudados para a cidade de Ubatuba-SP no ano 2012 para a cidade de Ubatuba -SP (IOUSP/Base Norte,2012).

Figura 10 : Acompanhamento das frentes frias ao longo do mês de Junho de 2012 (CPTEC/INPE,2002) 49

Figura 11 Acompanhamento do centro de baixa pressão na carta sinótica dos dias 18 à 22 de junho de 2012 sobre a região de Ubatuba-SP (Parte 1). 
Figura 12 Acompanhamento do centro de baixa pressão na carta sinótica dos dias 18 à 22 de junho de 2012 sobre a região de Ubatuba-SP (Parte 2).

Figura 13 Acompanhamento do centro de baixa pressão na carta sinótica dos dias 18 à 22 de junho de 2012 sobre a região de Ubatuba-SP (Parte $3)$.

Figura 14: Acompanhamento das frentes frias ao longo do mês de Julho de 2012 (CPTEC/INPE,2012)

Figura 15 Acompanhamento das frentes frias ao longo do mês de agosto de 2012 (CPTEC/INPE,2012) 55

Figura 16 Variação do nível do Mar em Ubatuba - SP durante o período estudado do ano de 2012 56

Figura 17 Incidências de ondas para a Enseada da Fortaleza (SMCBrasil,2013)

Figura 18 Simulação realizada pelo Sistema de Modelagem Costeira para ondas do quadrante Leste com altura de onda de 1 metro. 59

Figura 19 Simulação realizada pelo Sistema de Modelagem Costeira para ondas do quadrante Sul com altura máxima de onda de $3,85 \mathrm{~m}$. 60

Figura 20 Simulação realizada pelo Sistema de Modelagem Costeira para ondas do quadrante Sul com altura máxima de onda de 1,00 m. 61

Figura 21 Gráfico de variação topográfica entre os dias 19 e 20 de junho de 2012 para a praia do Lázaro 64

Figura 22 Gráfico de variação topográfica entre os dias 20 e 21 de junho de 2012 para a praia do Lázaro. 
Figura 23 Gráfico de variação topográfica entre os dias 21 e 22 de junho de 2012 para a praia do Lázaro 66

Figura 24 Gráfico de variação topográfica entre os dias 22 e 23 de junho de 2012 para a praia do Lázaro.

Figura 25 Gráfico de variação topográfica entre os dias 19 e 23 de junho de 2012 para a praia do Lázaro. 68

Figura 26 Gráfico de variação topográfica entre os dias 09 e 10 de julho de 2012 para a praia do Lázaro.

Figura 27 Gráfico de variação topográfica entre os dias 10 e 12 de julho de 2012 para a praia do Lázaro. 70

Figura 28 Gráfico de variação topográfica entre os dias 12 e 13 de julho de 2012 para a praia do Lázaro. 71

Figura 29 Gráfico de variação topográfica entre os dias 09 e 13 de julho de 2012 para a praia do Lázaro.

Figura 30 Gráfico de variação topográfica entre os dias 29 e 30 de Agosto de 2012 para a praia do Lázaro. 73

Figura 31 Gráfico de variação topográfica entre o último dia de junho e o primeiro dia de Julho de 2012 para a praia do Lázaro.

Figura 32 Gráfico de variação topográfica da Praia do Lázaro entre o último dia de julho e o primeiro dia de Agosto de 2012 para a praia do Lázaro. 75

Figura 33 Gráfico de variação topográfica entre o primeiro dia de junho e o último dia de Julho de 2012 para a praia do Lázaro. 76

Figura 34 Gráfico de variação topográfica da Praia Domingas Dias entre os dias 18 e 19 de Junho de 2012 78 
Figura 35 Gráfico de variação topográfica da Praia Domingas Dias entre os dias 19 e 21 de Junho de 2012.

Figura 36 Gráfico de variação topográfica da praia Domingas Dias entre os dias 21 e 22 de Junho de 2012. 80

Figura 37 Gráfico de variação topográfica da Praia Domingas Dias entre os dias 18 e 22 de Junho de 2012. 81

Figura 38 Gráfico de variação topográfica da praia Domingas Dias entre os dias 08 e 09 de Julho de 2012.

Figura 39 Gráfico de variação topográfica entre os dias 09 e 10 de Julho de 2012

Figura 40 Gráfico de variação topográfica entre os dias 10 e 12 de Julho de 2012 . 84

Figura 41 Gráfico de variação topográfica entre os dias 08 e 12 de Julho de 2012

Figura 42 Gráfico de variação topográfica entre os dias 29 e 30 de Agosto de 2012. 86

Figura 43 Gráfico de variação topográfica entre os dias 30 e 31 de Agosto de 2012.

Figura 44 Gráfico de variação topográfica entre os dias 29 e 31 de Agosto de 2012. 88

Figura 45 Gráfico de variação topográfica entre o último dia de junho e o primeiro dia de Julho de 2012. 89

Figura 46 Gráfico de variação topográfica entre o último dia de julho e o primeiro dia de Agosto de 2012. 90 
Figura 47 Gráfico de variação topográfica entre o primeiro dia de junho e o último dia de Agosto de 2012.

Figura 48 Gráfico de variação topográfica entre os dias 20 e 21 de junho de 2012 para a praia da Sununga.

Figura 49 Gráfico de variação topográfica entre os dias 21 e 22 de junho de 2012 para a praia da Sununga. 93

Figura 50 Gráfico de variação topográfica entre os dias 22 e 23 de junho de 2012 para a praia da Sununga.

Figura 51 Gráfico de variação topográfica entre os dias 20 e 23 de junho de 2012 para a praia da Sununga. 94

Figura 52 Gráfico de variação topográfica entre os dias 09 e 10 de julho de 2012 para a praia da Sununga. 95

Figura 53 Gráfico de variação topográfica entre os dias 10 e 12 de julho de 2012 para a praia da Sununga. 96

Figura 54 Gráfico de variação topográfica entre os dias 12 e 13 de julho de 2012 para a praia da Sununga. 96

Figura 55 Gráfico de variação topográfica entre os dias 09 e 13 de julho de 2012 para a praia da Sununga.

Figura 56 Gráfico de variação topográfica entre os dias 28 e 29 de Agosto de 2012 para a praia da Sununga. 98

Figura 57 Gráfico de variação topográfica entre os dias 29 e 31 de Agosto de 2012 para a praia da Sununga. 98

Figura 58 Gráfico de variação topográfica entre os dias 28 e 31 de Agosto de 2012 para a praia da Sununga. 99 
Figura 59 Gráfico de variação topográfica entre o último dia de Junho e o primeiro dia de Julho de 2012 para a praia da Sununga.

Figura 60 Gráfico de variação topográfica entre os último dia de Julho e o primeiro dia de Agosto de 2012 para a praia da Sununga.

Figura 61 Gráfico de variação topográfica entre o primeiro dia de Junho e o último dia de Agosto de 2012 para a praia da Sununga. 101

Figura 62 Gráfico de Diâmetro médio do sedimento para a Praia da Lázaro em Ubatuba -SP.

Figura 63 Gráfico de Diâmetro médio do sedimento para a Praia do Lázaro em Ubatuba -SP.

Figura 64 Gráfico de porcentagem de carbonato de cálcio do sedimento para a Praia do Lázaro em Ubatuba -SP

Figura 65 Gráfico de Diâmetro médio do sedimento para a Praia da Domingas em Ubatuba -SP 104

Figura 66 Gráfico do grau de seleção do sedimento para a Praia da Domingas Dias em Ubatuba -SP

Figura 67 Gráfico de porcentagem de carbonato de cálcio no sedimento da Praia da Domingas Dias em Ubatuba -SP

Figura 68 Gráfico de Diâmetro médio do sedimento para a Praia da Sununga em Ubatuba -SP.

Figura 69 Gráfico de porcentagem de carbonato de cálcio no sedimento para a Praia da Sununga em Ubatuba -SP.

Figura 70 Gráfico de Grau de seleção do sedimento para a Praia da Sununga em Ubatuba -SP. 


\section{Lista de tabelas}

Tabela 1 Dias amostrados para o ano de 2012. 43

Tabela 2 Tabela das precipitações nos dias de coleta para a cidade de Ubatuba-SP no ano de 2012 (IOUSP/Base Norte,2012). 46

Tabela 3 Tabela da temperatura média para os meses estudados na região de Ubatuba- SP no ano de 2012 (IOUSP/Base Norte,2012). 48

Tabela 4 Quadro síntese dos sistemas frontais correlacionados com as características de cada praia. 


\section{Sumário}

1. INTRODUÇÃO ..........................................................................................................................................

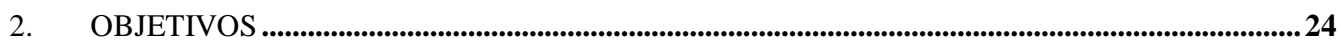

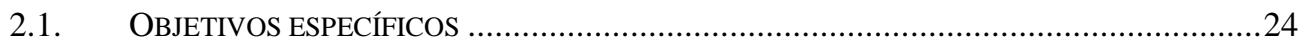

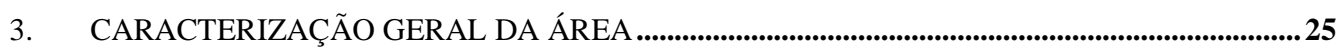

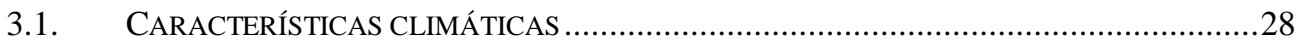

3.2. CARACTERÍSTICAS OCEANOGRÁFICAS ...............................................................

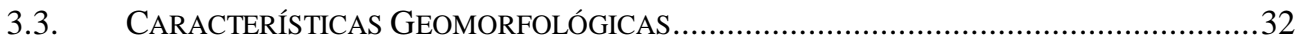

4. MÉTODOS ………..............................................................................................................................35

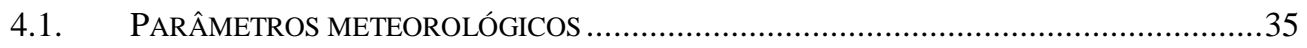

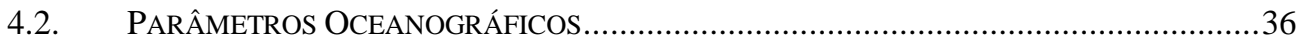

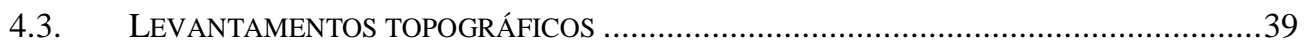

4.4. COLETA E ANÁLISE DE SEDIMENTOS PRAIAS ……………………........................42

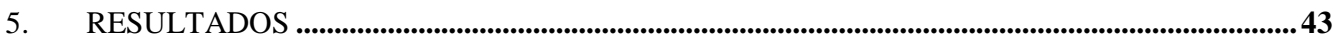

5.1. CONDIÇÕES CLIMÁTICAS AO LONGO DO PERÍODO AMOSTRADO ………………..........43

5.2. CONDIÇÕES MAREGRÁFICAS AO LONGO DO PERÍODO ……………………………....56

5.3. Dados de Ondas do Sistema de Modelagem Costeira (SMC) ..........................56

5.4. VARIAÇÕES TOPOGRÁFICAS DOS PERÍODOS AMOSTRADOS .......................................62

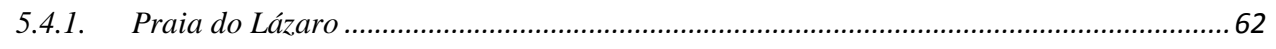

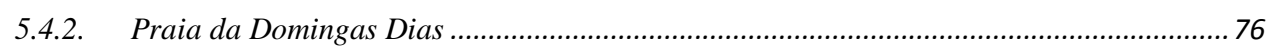

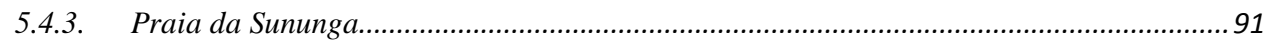

5.5. Granulometria e Teor de Carbonato de CÁlcio (CACO3) …………...........102

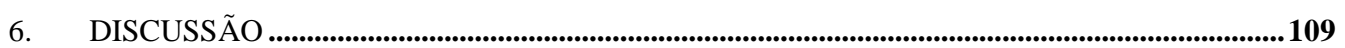

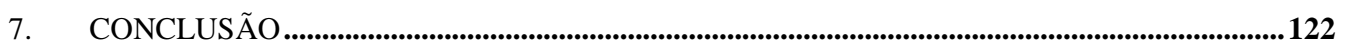

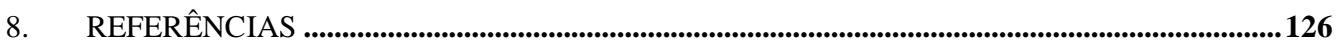




\section{Introdução}

A região costeira é um dos ambientes mais dinâmicos e complexo do planeta, por ser uma transição entre os ambientes marinho, continental e atmosférico, ao lado da sua grande importância social e econômica.

Sob o ponto de vista geomorfológico, a linha de costa se caracteriza por instabilidade decorrente de alterações por efeitos naturais e antrópicos, que se traduzem em modificações na disponibilidade de sedimentos, no clima de ondas e na altura do nível atual relativo do mar. Analisada no contexto morfodinâmico, uma praia é o resultado dos elementos morfológicos e granulométricos, combinados com os elementos energéticos provenientes dos ventos, ondas e corrente. A praia é um ambiente naturalmente dinâmico e as variações dos perfis transversais à praia resultam da energia das ondas a que estes perfis estão submetidas (MUEHE, 2009; WRITGHT et al, 1978 ).

De acordo com Tessler e Mahiques (1994), os mecanismos de circulação atmosférica condicionam a dinâmica sedimentar da plataforma interna dos litorais sul e sudeste brasileiros.

Os diferentes graus de exposição das praias aos fatores hidrodinâmicos, responsáveis pela alteração no perfil praial, são função, principalmente, da orientação da linha de costa (PUGH, 1986). Essa diferença de graus de modificação entre as praias deve-se a localização dos segmentos praiais em relação ao comprimento total da pista de vento ao longo do oceano. Assim, praias localizadas próximo ou distante da pista sofrerão respectivamente menor e maior alteração. Fatores adicionais relacionados à diferentes orientações da linha de costa, estágio praial e a morfologia da antepraia contribuem para acentuar diferenças espaciais nos volumes acrescidos ou retirados do prisma praial. 
As praias variam as suas características granulométricas e morfológicas em função de fatores geológicos, geomorfológicos e oceanográficos. A morfologia de uma praia em um determinado tempo é função das características dos sedimentos, das ondas imediatas e antecedentes, das condições de maré e de vento, e do estágio de praia antecedente.

Segundo Muehe (2005), o monitoramento morfodinâmico permite o acompanhamento espaço-temporal de ciclos de erosão/deposição e definição de patamares esperados de variação morfológica (volumétrica), o que consequentemente aumenta o grau de sucesso das diversas atividades relacionadas ao gerenciamento de zonas litorâneas.

Igualmente ao ocorrido no Brasil, diversos autores realizaram estudos quanto às relações espaço temporais da ação dos sistemas frontais, dinâmica de ondas e marés sobre prismas praias em setores praias, distribuídos ao longo dos hemisférios sul e norte.

Wright e Short (1984), fazem uma síntese de alguns resultados obtidos nas praias da Austrália ao longo do período de 1979 à 1982, considerando os processos dinâmicos atuantes nas praias e zona de surfe. Esses autores abordam principalmente, as caracterísicas morfológicas e dinâmicas dos diferentes estágios naturais das praias e a influência da ação das frentes frias nos processos de mudanças morfológicas. O trabalho aponta também a ação das ondas de tempestade e frentes frias como os principais fatores para as alterações morfológicas sobre as atuais linhas de costa.

Em decorrências das características específicas da costa sudeste australiana, outras propostas de classificação foram feitas. Algumas vezes, essas propostas tem 
caráter complementar, como a de Masselink e Short (1993), sugerindo a influência do regime e dinâmica de marés na morfodinâmica praial.

Bryant (1987) estudou as tempestades costeiras ao longo da costa New South Wales, utilizando uma compilação de dados de tempestades costeiras e maré extaídas de 105 fotografias oblíquas. Os dois conjuntos de dados estão entre os melhores de seu tipo no mundo. Os resultados obtidos influenciam as implicações para outras praias em que os fatores individuais, tais como tempestades ou elevação do nível do mar podem não ser necessariamente os melhores fatores para explicar as causas da variação morfodinâmica.

Dail et.al (2000) realizaram estudo em Waimea Bay, Hawaii, para avaliar as modificações na morfologia de praia de bolso, associadas a diferentes níveis de energia de ondas. Segundo os autores, esse tipo de praia não está fortemente influenciado pelo transporte ao longo da costa estando condicionada principalmente pela dinâmica de ondas, produzindo transporte onshore-offshore. A metodologia utilizada consistiu em levantamentos diários, em situações de tempo bom e condições antecedentes e posteriores a uma tempestade, utilizando um GPS de precisão, permitindo que toda a praia fosse recoberta pelo levantamento e possibilitando verificar todas as direções de transferência de material.

Sallenger (2000) propôs uma escala para mesurar os impactos das tempestades em ilhas barreiras, utilizando dados sobre perfis topográficos em duas ilhas localizadas na costa atlântica dos EUA. As Isles Denieres; localizadas na cidade de Nova Orleans Lousiana; apresentaram um grau de suscetibilidade aos impactos causados por tempestades maior que a praia de Duck, localizada na costa da Carolina do Norte. As duas localidades estão expostas a eventos atmosféricos de intensidades similares, no 
entanto a geometria das duas praias difere grandemente, visto que as Isles Denieres se elevam somente 1,5 m acima do nível médio mar, enquanto Duck se eleva cerca de $6 \mathrm{~m}$.

Benavente, et. al (2002), lidam com a estimativa de suscetibilidade de praias à tempestades na Baía de Cádiz, no sudoeste da Espanha, e suas implicações ambientais. Para este estudo, foi feita uma comparação entre o comportamento natural das praias e do dano costeira causado por ondas energéticas em todos os tipos de praia. O comportamento morfodinâmico das praias foi obtido a partir de monitoramento topográficos mensais, realizado durante 30 meses consecutivos. Com esse trabalho foi possível estabelecer a resposta de diferentes estágios morfodinâmicos praiais durante a passagem da frente fria e estabelecer uma matriz de suscetibilidade dessas praias. Por esta razão, a prevenção de efeitos da tempestade deve incluir o conhecimento sobre a distribuição geográfica e, principalmente, sobre a eficiência de todo o tipo de praia em proteger os ambientes terrestres.

Capo et al. (2009) usaram quatro DGPS para estudar as modificações de escala temporal curta associadas a tempestades na praia Truc Vert na França. Dois aparelhos foram usados por pesquisadores a pé na obtenção de perfis topográficos, um aparelho foi acoplado a quadriciclo e o último foi montado em uma caixa estanque para aquisição de dados nos limites da zona de surfe e espraiamento. Os autores usaram os resultados para quantificar os efeitos das tempestades e classificar a praia morfologicamente. Os resultados apresentaram uma forte variação espacial com a influencia das ondas na morofologia da praia. $\mathrm{O}$ trabalho apresentou bons resultados com um erro associado aos dados abaixo dos $3 \mathrm{~cm}$. 
No Brasil, os estudos em ambientes praiais sob o aspecto dinâmico e evolutivo iniciaram-se nos litorais leste, sudeste e sul, ao longo da década de 1970 (HOEFEL, 1998).

O primeiro trabalho a descrever mudanças morfodinâmica de praias associadas à passagem de sistemas frontais foi de Kowsmann (1970), ao estudar a praia de Copacabana, no Rio de Janeiro.

Farias et. al. (1985) e Bittencourt et. al. (1987) realizaram trabalhos de destaque na Praia da Armação (BA) estudando variações espaço temporal, através dos quais foi possível verificar variações da ordem de 3 metros no volume dos envelopes do prisma praial. Estas significativas variações métricas foram atribuídas à frequência de frentes frias que atingem a costa baiana no outono e inverno.

Rosman e Valentin (1989) realizaram um estudo aplicativo enfocando a ação de tempestade na praia do Leblon, no Rio de Janeiro, a partir de uma maré meteorológica em 1978 que erodiu um pacote arenoso do prisma praial de cerca de $3 \mathrm{~m}$ de espessura.

Calliari et.al (1994) estudou as praias entre Rio Grande e Chuí analisando as respostas destes segmentos praias à passagem de sistemas frontais de alta energia e constatou que a passagem dos sistemas frontais dão características mais refletivas a estas praias, gerando uma maior remobilização de sedimento do prisma praial.

Cazzoli (1997) faz um apanhado de vários trabalhos que apontaram a passagem de sistemas frontais como agente modificador da dinâmica praial no litoral sul/Sudeste associados à modificação da morfodinâmica praial. Os resultados obtidos demonstraram que, apesar do predomínio da ação do Anticiclone Tropical do Atlântico Sul (ATAS), a dinâmica sedimentar de ambas as praias esteve controlada principalmente pela 
incidência de sistemas frontais que resultou em um transporte mais efetivo rumo NE Nessa compilação é ressaltada à ciclicidade entre os eventos erosivos e deposicionais, sendo os períodos com maior passagem de sistemas frontais, os mais erosivos.

Klein et al. (1997) estudando a variabilidade temporal da praia semi protegida de Camboriú, notaram que as variações de volume de sedimentos na face praial foram condicionadas por variações nas direções dos trens de ondas, sendo cíclicas e menos bruscas que aquelas verificadas em praias expostas ou oceânicas.

As primeiras referências quanto às características do litoral norte paulista, data do princípio do século passado, constituindo basicamente das descrições da paisagem. Após esta fase Ab'Saber (1955), foi um dos pioneiros na caracterização das feições geomorfológicas do litoral servindo de base para os estudos dos processos dinâmicos da zona costeira dessa região.

Mais especificamente estudos associados à variabilidade temporal e espacial dos ambientes costeiros do litoral norte do estado de São Paulo e especificamente na Enseada da Fortaleza, Ubatuba, SP podem ser referidos à Mahiques (1992) que definiu um padrão de sedimentação para a região costeira de Ubatuba, litoral norte do estado de São Paulo, a partir da identificação dos mecanismos principais de aporte e remobilização de sedimentos e da definição de sua variabilidade temporal.

A enseada da Fortaleza é composta basicamente de praias de enseada, de diferentes orientações, graus de exposição e fortemente afetada pela passagem de sistemas frontais. Estudos morfodinâmicos relacionados a processos meteorológicos são muito importantes nessa região, por permitir correlacionar de forma direta uma comparação entre os eventos climáticos extremos e os diferentes níveis de modificação dos primas praias do litoral Norte paulista. 
Andrade (2002) estudou os processos hidrodinâmicos e sedimentares da Enseada da Fortaleza, detalhando os processos, visando compreender sua influência na dinâmica sedimentar atual da plataforma interna norte paulista. A autora concluiu que as areias depositam-se na área interna, sendo retrabalhadas nos períodos mais energéticos e a maior parte do sedimento lamoso é levada para regiões mais distantes da plataforma, sendo que a enseada vem se comportando como uma armadilha para sedimentos mais grossos e serve como conexão na transferência de parte dos sedimentos mais finos.

Barros \& Tessler (2003) avaliaram a morfodinâmica das praias da Fazenda, Puruba e Itamambuca localizadas no setor norte do município de Ubatuba. O estudo foi efetuado por meio de perfis topográficos mensais durante 14 meses em conjunto com coletas de sedimento e caracterização das ondas incidentes e dos sistemas meteorológicos atuantes. Os autores também associaram as modificações nos processos sedimentares aos diferentes sistemas meteorológicos presentes durante as coletas, relacionando as ondas de $\mathrm{NE}$ e $\mathrm{N}$, formadas pelo ATA, a situações construtivas e as ondas de S e SE, formadas pelos APMs, a processos erosivos.

Martins (2006) aplicou pela primeira vez neste segmento costeiro estudos de reduzida variabilidade temporal e espacial, com a utilização de um DGPS na Praia da Sununga em Ubatuba, São Paulo. Sabendo-se que esse seguimento não possuía influência atual de dinâmica fluvial, foi possível avaliar a dinâmica local relacionada unicamente aos agentes oceanográficos, tendo como fonte de sedimento a antepraia adjacente e os costões rochosos. O trabalho classificou a dinâmica deste setor praial como intensa, concluindo que essa praia é controlada pela dinâmica de ondas que resultam em um processo de rotação praial. 


\section{Objetivos}

O principal objetivo desse estudo é caracterizar a variabilidade espaço temporal dos prismas praias das praias do Lázaro, Domingas Dias e Sununga em relação às variáveis meteorológicas e oceanográficas, condicionadas pela passagem dos sistemas frontais, proporcionando à compreensão da evolução morfológica deste segmento costeiro da Enseada da Fortaleza.

\subsection{Objetivos específicos}

Paralelamente a este objetivo pretende-se estabelecer um padrão de comportamento da variabilidade praial para cada tipo de ondulação incidente entre as praias de enseada do litoral Norte paulista em função do grau de exposição de cada segmento praial aos sistemas de ondas incidentes, ocasionados por climas de 'tempo bom"' e os resultantes das passagens de sistemas frontais. 


\section{Caracterização geral da área}

O litoral paulista pode ser dividido em três áreas geomorfologicamente distintas conforme descrito em Suguio e Martin (1978). A primeira ao sul é caracterizada pela presença de longos segmentos retilíneos de praias, ladeados por planícies costeiras desenvolvidas entre a atual linha de costa e a Serra do Mar. A segunda é denominada de Baixada Santista, onde se desenvolveram grandes planícies costeiras menos extensas do que as observadas no litoral sul, separadas uma das outras por pontões do embasamento cristalino, incluindo o complexo do estuário e baía de Santos. A terceira área esta localizada mais a norte, até a divisa política com o estado do Rio de Janeiro, onde predominantemente o embasamento Pré-Cambriano (Serra do Mar) atinge a atual linha de costa em quase toda a sua extensão.

O município de Ubatuba está localizado no setor em que a escarpas da Serra do Mar mais se avizinham do oceano e, em decorrência disso, caracteriza-se por apresentar uma linha de costa recortada, composta por varias enseadas semi-confinadas, limitadas por pontões do embasamento cristalino que avançam em direção ao mar. (Andrade, 2002)

A Enseada da Fortaleza apresenta desembocadura voltada para sudeste, o que determina a forte influência dos trens de ondas vindos de S-SE, que se formam em situações de passagem de sistemas de frentes frias. Existem sistemas frontais quentes onde as ondas vem de NE, pois é um recuo do sistema frontal.

O trabalho se desenvolveu em parte do litoral Norte do Estado de São Paulo, no município de Ubatuba, nas praias do Lázaro (23³0’01.50’'S e 23³0’29.53 'S,

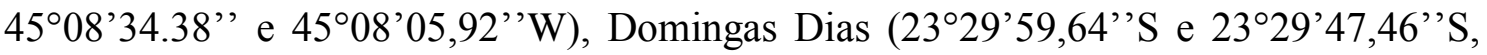


$45^{\circ} 08^{\prime} 36.90^{\prime \prime}$ e $\left.45^{\circ} 08^{\prime} 48,16^{\prime \prime} \mathrm{W}\right)$ e Sununga $\left(23^{\circ} 29^{\prime} 30^{\prime}\right.$ 'S e $23^{\circ} 32^{\prime} 30^{\prime}$ 'S, $45^{\circ} 06^{\prime} 30^{\prime \prime} \mathrm{W}$ e $45^{\circ} 10^{\prime} 30^{\prime \prime} \mathrm{W}$ ) (Figura 1).

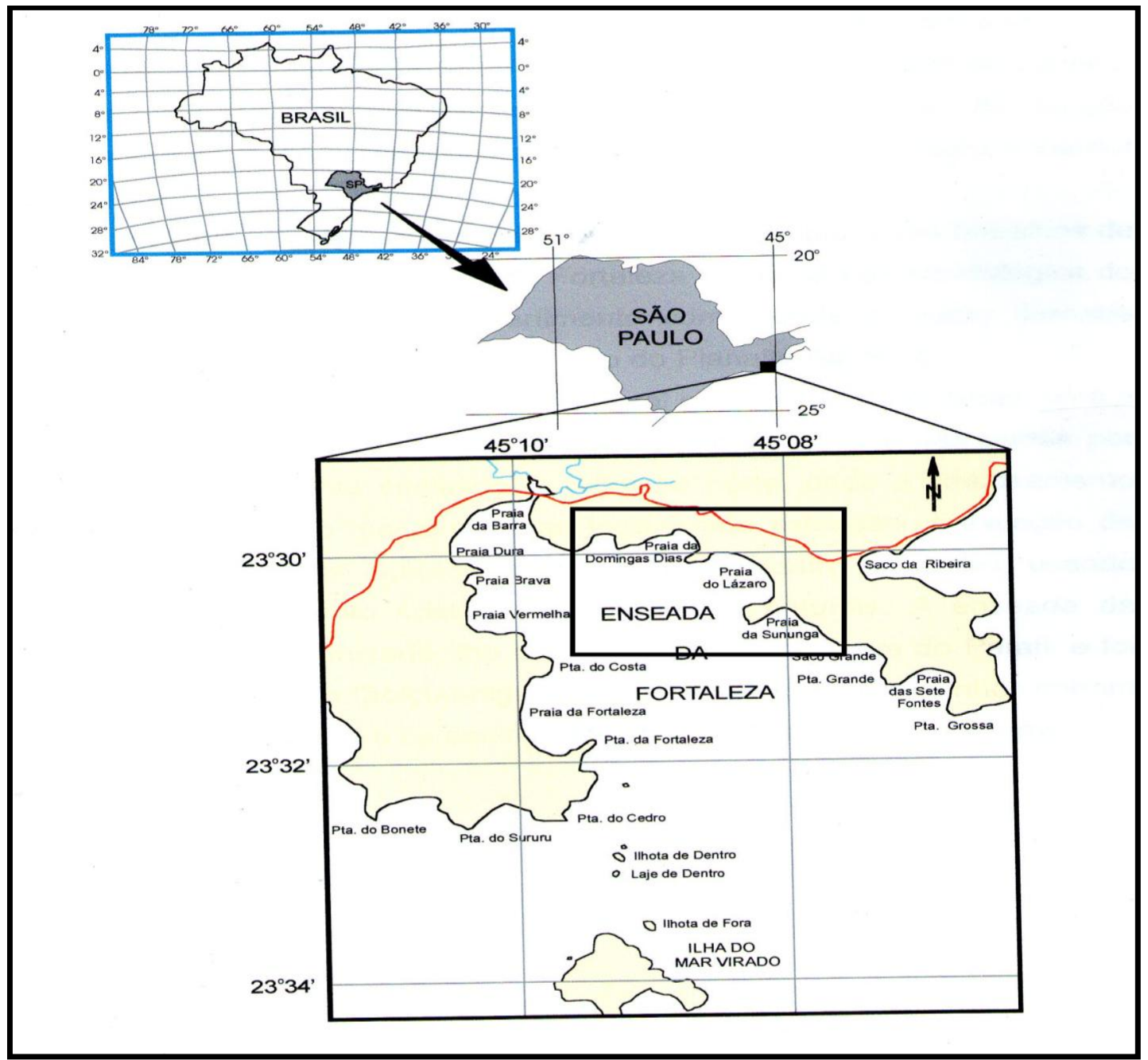

Figura 1- Mapa de localização da área de estudo (adaptado de Andrade,2002).

A Enseada da Fortaleza totaliza $11,65 \mathrm{~km}^{2}$ de extensão e possui 11 praias de enseada. Sua forma é aproximadamente triangular e apresenta profundidade entre 10 e 12 metros na sua desembocadura (Andrade, 2002). Recebe descarga da bacia do Rio Escuro, uma das mais volumosas da região de Ubatuba.

A praia da Sununga é uma praia de bolso, margeada por dois costões rochosos de pequena extensão, apresentando característica refletiva, com alto retrabalhamento sedimentar e rotação praial. (MARTINS,2006) (Figura 2). 
A praia do Lázaro, margeada em seu lado esquerdo pela praia da Sununga e em seu lado direito pela praia da Domingas Dias, é uma praia mais extensa, em relação as que a margeiam, apresentando tendências intermediárias à dissipativas (Figura 2).

A praia da Domingas Dias apresenta-se com as águas mais calmas dentre as três, possui uma pequena extensão de aproximadamente 400 metros e predominantemente um perfil praial intermediaria a refletivo (Figura 2).

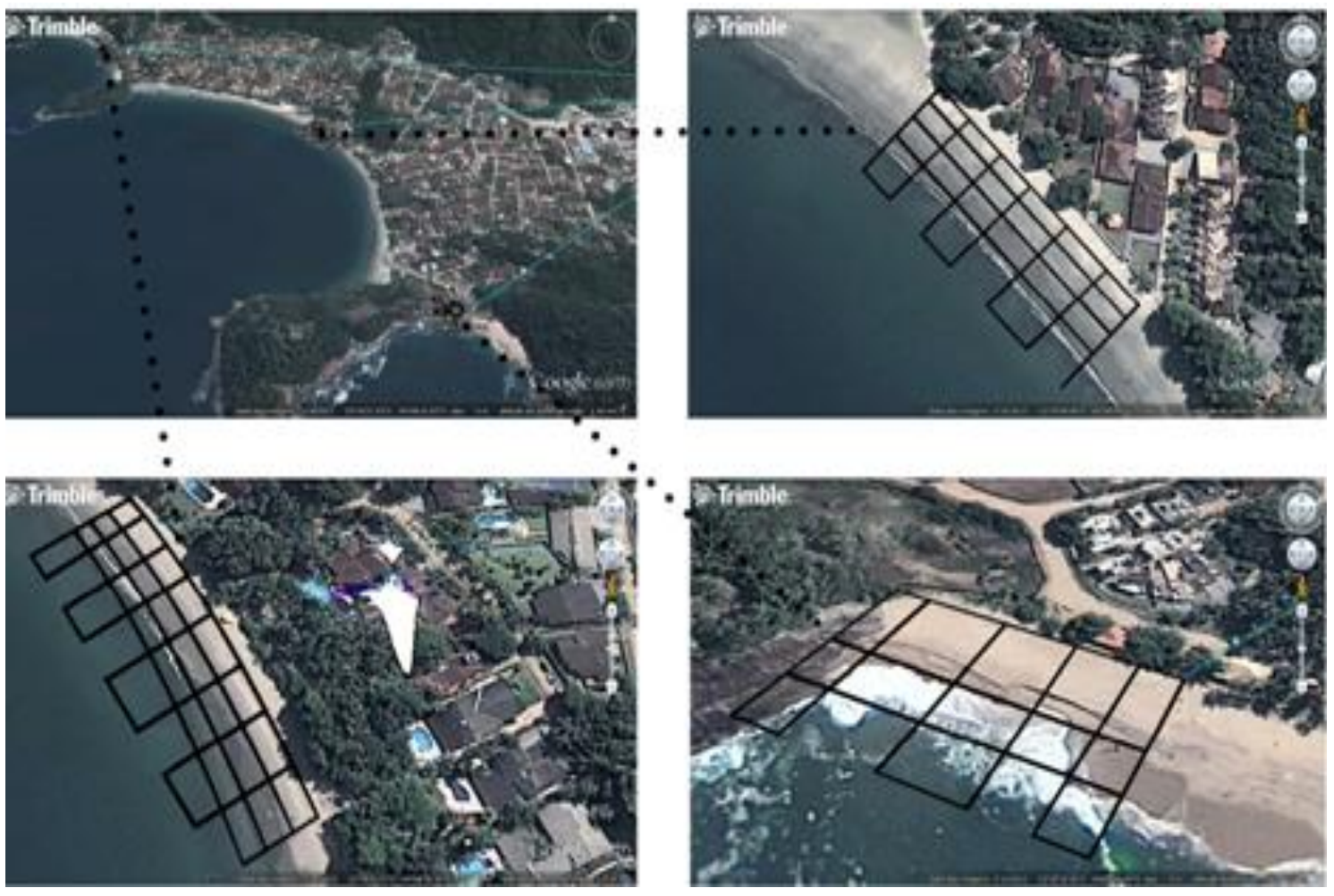

Figura 2 Foto aérea das praias estudas e dos trechos amostrados.

As características geológicas e morfológicas da área são fortemente controladas pela presença de granitos e migmatitos da Serra do Mar (altitudes acima de $1.000 \mathrm{~m}$ ), que atingem a costa em quase toda a região de estudo, limitando a extensão dos sistemas de drenagem, e de planícies costeiras Quaternárias ( IPT,1981, Mahiques, 1992; Oliveira et. al, 2005). 


\subsection{Características climáticas}

Os dados climáticos oferecem poderosos instrumentos de análise em estudos de dinâmica praial, uma vez que respondem diretamente pelos fenômenos de deslocamento do nível médio do mar, na circulação das águas costeiras e pelas ondas geradas pelas condições meteorológicas reinantes (Martins, 2000). Portanto, a análise dinâmica do tempo é fundamental para a definição e compreensão dos processos erosivos e deposicionais costeiros.

O litoral paulista sofre alternância de duas massas de ar, uma de origem tropical marítima e outra polar marítima. A escala regional dos anticiclones migratórios do sul ou Anticiclones Polares Móveis (APM), antecedidos pelas frentes frias são os responsáveis pelas frontogêneses no sul do país (MARTINS,2006).

Quando uma massa de ar se desloca, a sua parte dianteira passa a ser conhecida por frente. A massa de ar em deslocamento vai-se modificando, porque encontra condições de superfície diferentes, e o seu movimento provoca variações de pressão. No seu movimento, as massas de ar de diferentes características de temperatura, pressão e umidade, encontram-se, dando origem ao chamado sistema frontal, que é composto, de um modo geral, por uma frente fria, o motor do sistema, e uma frente quente que a antecede (MARTINS,2006).

Quando se aproxima da costa uma frente fria desloca parcelas da camada superficial oceânica, gerando assim ondulações, que dependendo da velocidade a qual a massa de ar se desloca e consequentemente da intensidade dos ventos, podem possuir ondas de maior altura e energia ${ }^{1}$. Na plataforma sul-sudeste do Brasil, esses distúrbios atmosféricos podem provocar sobre-elevações do nível do mar (ROCHA et al. 2004),

${ }^{1}$ SOARES, I. D. Dinâmica dos Oceanos. 2002. Apostila direcionada para os alunos de Graduação do curso de Oceanologia da FURG. 208p. 
alterações no nível médio da maré, e consequentemente podem ter influência direta sobre a variabilidade espacial (erosão/deposição) das praias.

Os anticiclones associados ao ar tropical ou Anticiclone Tropical Atlântico (ATA) ou ainda, anticiclones semi-permanentes do Atlântico são responsáveis pela geração de vento do oceano para o continente durante todo o ano. O Anticiclone Tropical Atlântico (ATA), relaciona-se aos ventos alísios, predominando direções NE e NW, com sentido anti-horário na latitude sul, o que favorece a formação de ondas provenientes de quadrantes a norte ocasionando a propagação de correntes de deriva litorânea de direção SW, em relação à costa do Estado de São Paulo, orientada segundo direção geral NE-SW (MARTINS,2006).

A principal característica dos Anticiclones Polares Móveis (APM) é o desenvolvimento de sistemas frontais, que acarretam precipitações e mudança na direção do vento, que passa a soprar dos quadrantes $S$, responsável por sistemas de ondas de S e SE, principais elementos geradores das correntes de deriva litorânea que percorrem a costa com rumo geral nordeste (MARTINS,2006).

Segundo Nimer (1989) a Frente Polar Atlântica, originada do Sistema Polar Atlântico é formada pelas massas que deixam o continente antártico e invadem o continente Sul-Americano. No Brasil, a frente se desloca para nordeste com ventos fortes e ondulações ciclônicas, sobretudo no mar, gerando ondas altas de SE e S, e prosseguindo em seu percurso até o paralelo de $22^{\circ}$ aproximadamente, onde perde a nitidez devido à influência dos ventos alísios de NE.

A passagem da frente fria envolve três momentos distintos quanto aos aspectos meteorológicos: 1) a entrada da frente fria ou pré- frontal indicada por ventos de SW, elevação da temperatura, queda da pressão, queda na insolação média diária, aumento 
da nebulosidade e queda da umidade relativa. 2) com a chegada da frente, nota-se uma queda na temperatura em alguns graus, seguida de elevação brusca da pressão. Caso a massa de ar sobre a região seja quente e úmida, com a entrada da frente ocorrerá um deslocamento brusco das massas de ar, provocando chuvas torrenciais, com predomínio de tempo instável, que se dissipará com a passagem da frente para norte ou para leste. 3) o pós - frontal, manifesta - se pela queda da temperatura e elevação da umidade relativa, pela advecção do centro do anticiclone (MARTINS, 2006).

Existe uma variação de frequência na distribuição das perturbações de acordo com as estações do ano, tendo sua maior frequiência marcada pelo período de transição entre o domínio das massas de ar predominantes, o ATA e o APM (março - abril, outubro - novembro) (MARTINS,2006).

Durante os meses de inverno, no litoral Sudeste do Brasil a ocorrência de sistemas frontais é maior (SUGAHARA, 2000; SILVA; SILVA DIAS, 2002) e a pluviometria média anual é cerca de $803 \mathrm{~mm}$, com as intensidades máximas sendo observadas em Fevereiro (OLIVEIRA et.al.,2005).

Calliari et.al, 2012 definiu 4 padrões sinóticos geradores de eventos extremos de tempestades para o Sul do Brasil. O Padrão I é referente a ciclogênese na costa sul da Argentina com um deslocamento para o leste e uma trajetória entre $47,5^{\circ} \mathrm{S}$ e $57,5^{\circ} \mathrm{S}$; o padrão II referente a Ciclogênese na costa sul do Uruguai com um deslocamento para o leste e uma trajetória entre $28^{\circ} \mathrm{S}$ e $43^{\circ} \mathrm{S}$; o padrão III referente a Ciclogênese na costa sul do Uruguai com um deslocamento para o sudeste e uma trajetória entre $32^{\circ} \mathrm{S}$ e $57,5^{\circ} \mathrm{S}$ e o padrão IV no centro de alta pressão (anticiclone), gerando vento e ondas de leste (Fig. 3). O padrão de maior ocorrência durante o período de 64 anos para o Brasil 
foi o tipo III com 38 dos 89 casos, entretanto o padrão II ficou logo atrás representado por 36 casos.
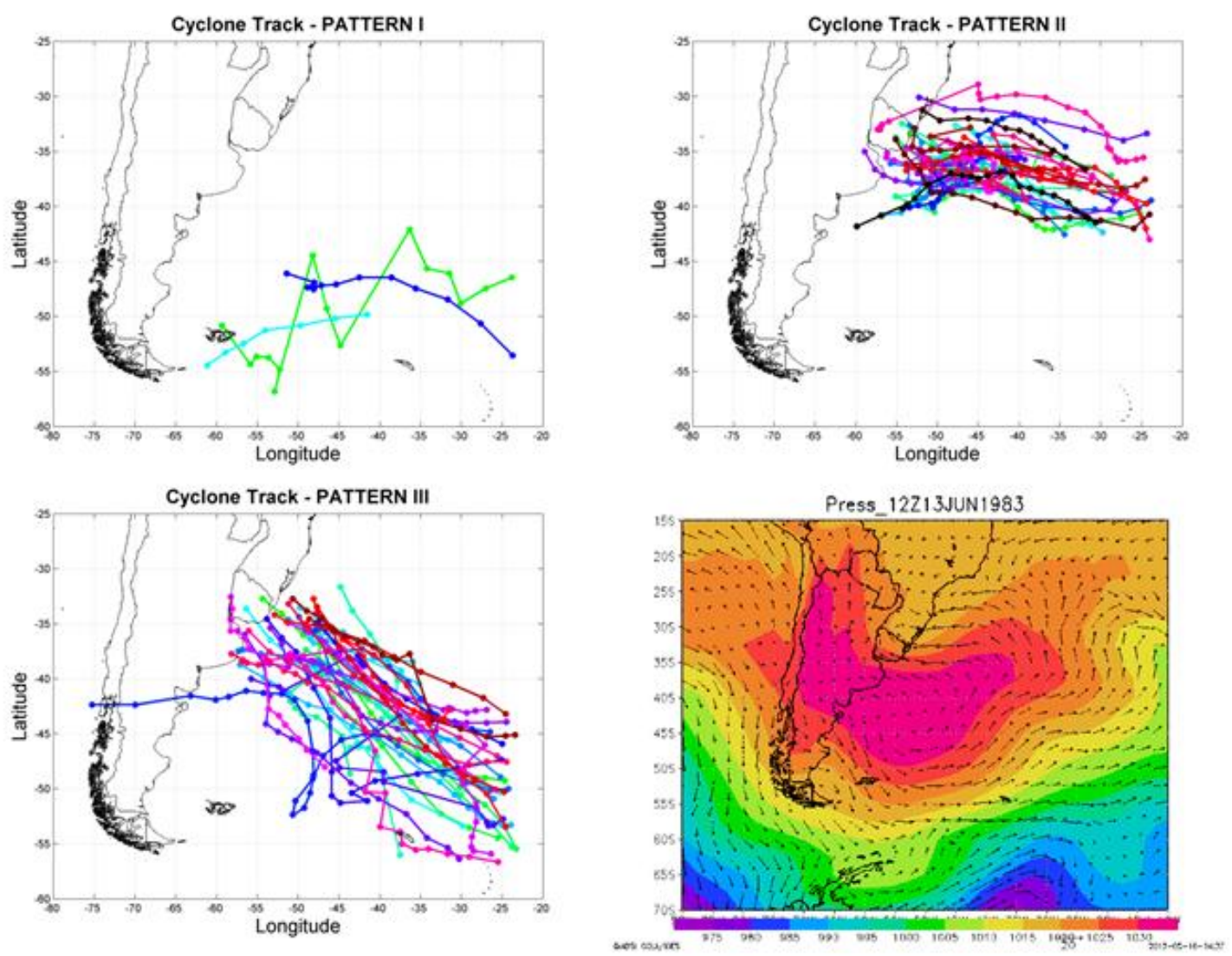

Figura 3 Os quatros padrões sinópticos de eventos eventos de velocidade do vento: (A) Padrão I, (B) Padrão II, (C) Padrão III, (D) Padrão IV (Calliari, 2012)

\subsection{Características Oceanográficas}

Duas direções predominantes das ondas atingem o litoral norte paulista. As ondas provenientes dos quadrantes a $\mathrm{S}(\mathrm{S} ; \mathrm{SE} ; \mathrm{SW})$ que estão associadas à passagem de frentes frias e as ondas provenientes dos quadrantes a E-NE associados aos centros de geração semi-permanentes do Atlântico Sul e também aos eventos pós-frontais. A interação dessas ondas com a orientação e dimensão das bocas das enseadas, além da 
presença de ilhas na plataforma interna, conferem características distintas na dinâmica das baias, e consequentemente, na evolução morfodinâmica das praias de enseada apesar de todas elas serem consideradas baías fechadas (OLIVEIRA et. al, 2005).

A dinâmica da praia é fortemente influenciada pela incidência dos trens de ondas, que na costa de São Paulo não apresentam associação direta com os ventos locais e sim com os ventos gerados no oceano. Os provenientes do centro gerador, localizado ao norte, predominam na região durante a maior parte do período, ocorrendo, associadas a ele, as ondas com as menores alturas, compreendidas entre 0,5 e 1,0 metros e período predominante entre 06 e 20 segundos (PONÇANO et.al.,1999).

Segundo Hoefel (1998), ondas altas, muito esbeltas e de alto período, características de condições de alta energia (ou seja, tempestades ou passagem de sistemas frontais), propiciam a migração de grandes volumes de sedimento em direção ao mar, depositando-os na zona de surfe sob forma de bancos longitudinais. Com o decaimento dos níveis energéticos, a incidência de ondas mais baixa e menos esbeltas transportaria novamente os sedimentos em direção à praia, fazendo os bancos migrarem até soldarem-se a mesma (condições de tempo bom).

\subsection{Características Geomorfológicas}

O Litoral Norte é fortemente condicionado pelo embasamento cristalino que alcança o mar, predominando então, pequenas enseadas e praias de bolso formadas por depósitos continentais na sua porção interna e marinha na porção externa (FULFARO et al, 1974).

As flutuações do nível relativo do mar constituem elemento importante na evolução das planícies costeiras brasileiras, sobretudo no Quaternário. 
A formação geológica dessa região foi descrita por Suguio e Martin (1978) e caracterizada por dois grandes episódios transgressivos subsequentes, onde os níveis marinhos se projetaram em níveis superiores aos atuais (Fig. 4).

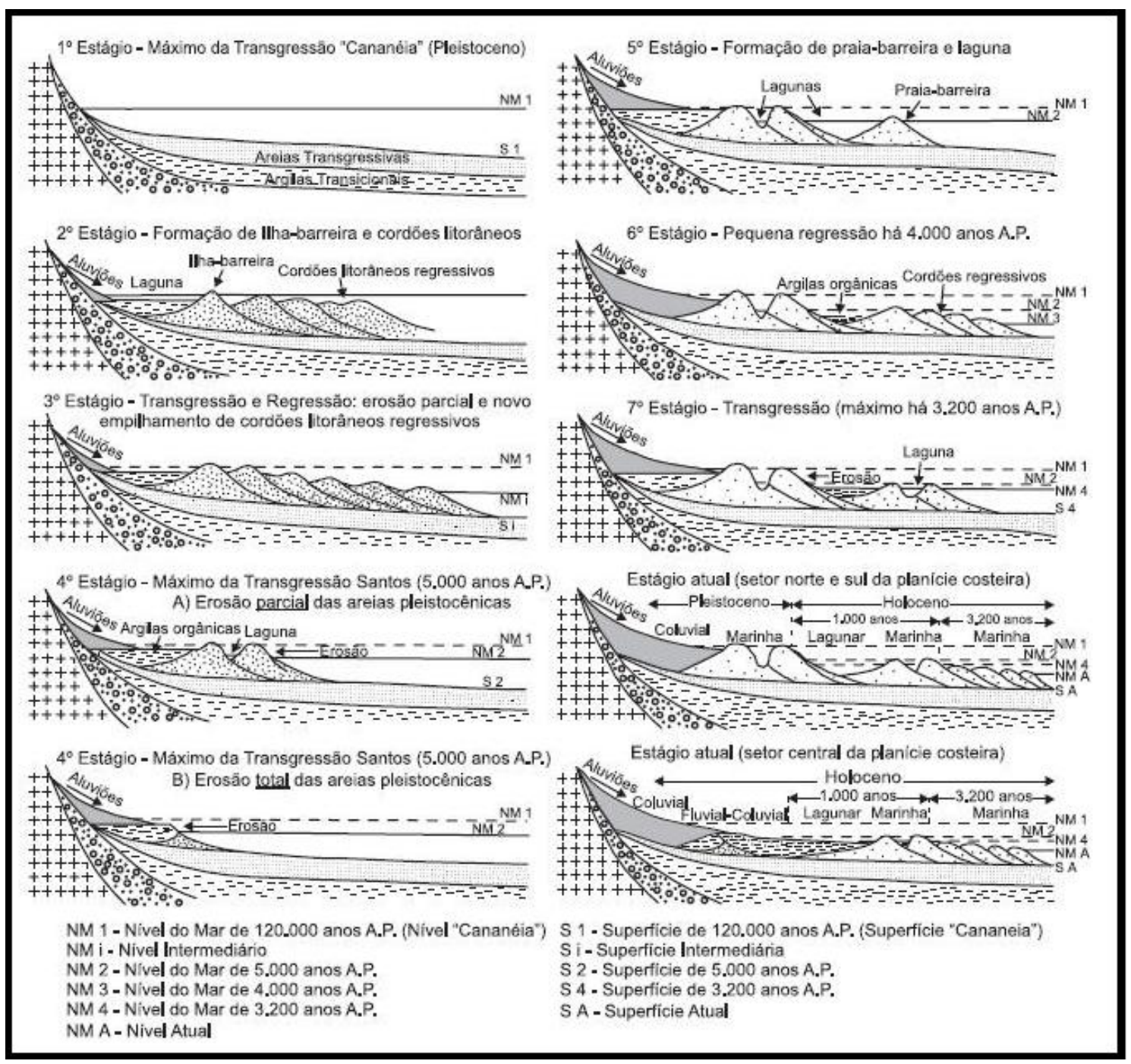

Figura 4 Formação quaternária do litoral Norte Paulista (Suguio e Martin, 1978)

Ao longo do Quaternário, dois ciclos transgressivos e regressivos modelaram as planícies costeiras brasileiras, consequência de oscilações relativas do nível do mar. $\mathrm{O}$ primeiro ciclo, de idade pleistocênica ( 120000 anos A.P.), atingiu cotas de $8 \pm 2$ metros acima do nível atual. Este evento foi denominado como Transgressão Cananéia no trecho da costa paulista (SUGUIO E MARTIN,1978). A partir do máximo transgressivo 
pleistocênico, o nível do mar recuou até posições ao redor da isóbata de 110 metros abaixo do nível atual, há cerca de 17000 anos A.P. Ao longo deste processo de regressão marinha, a atual plataforma continental foi quase totalmente exposta, sendo sulcada por vales fluviais (SUGUIO E MARTIN,1978).

Desta forma, ao longo do Pleistoceno, em cerca de cem mil anos (120000 17000 anos A.P.), ocorreu uma variação aproximada de 118 metros do nível relativo do mar. Neste período, de um modo simplista, verifica-se uma taxa média de variação relativa do nível do mar de 0,19 cm/ano (SUGUIO E MARTIN,1978).

A partir do máximo regressivo, o nível relativo do mar foi submetido a uma nova elevação, tendo atingido há cerca de 7000 anos A.P., um nível próximo do zero atual. Este processo transgressivo se manteve até 5100 anos A.P., atingindo quatro metros acima do nível atual. Esta foi denominada para o litoral paulista de Transgressão Santos (SUGUIO e MARTIN, 1978). 


\section{Métodos}

Os métodos empregados nos levantamentos de campo, na compilação de informações bibliográficas e nas análises dos conjuntos de dados estabelecidos são descritos prioritariamente associados aos conjuntos de informações resultantes de cada uma das aplicações metodológicas.

\subsection{Parâmetros meteorológicos}

Os dados das variações meteorológicas foram obtidos através de medições diretas e indiretas ao longo do período de aquisição de dados.

Foram utilizados dados de observação de precipitação e temperatura registrados na estação meteorológica localizada na Base Norte do IOUSP, em Ubatuba e das informações contidas nas cartas sinóticas disponibilizadas pelo Serviço Meteorológico Marinho da Diretoria de Hidrografia e Navegação (DHN) da Marinha do Brasil.

Utilizou-se para cada dia de amostragem um acompanhamento meteorológico através das cartas sinóticas, de condições e previsão do tempo para área marítima de responsabilidade do Brasil (Meteoromarinha). O levantamento de dados é referente à área "Charlie" que vai desde o Cabo de Santa Marta até o Cabo Frio. O acompanhamento meteorológico serviu de base principalmente para determinação da circulação atmosférica e consequentemente para caracterização dos trens de ondas incidentes na Baía de Santos, nos dias de coleta.

As cartas sinóticas e o boletim Climanálise, disponibilizado pelo INPE, foram utilizados para a identificação do número de sistemas frontais que atuaram junto à costa 
do Estado de São Paulo no período estudado e dados de ventos associados a esses sistemas.

\subsection{Parâmetros Oceanográficos}

Os dados de maré referentes aos períodos de levantamento de campo foram obtidos a partir do marégrafo localizado na Base Norte do Instituto Oceanográfico, em Ubatuba.

Devido à proximidade da área do levantamento praial com a localização do marégrafo (Saco da Ribeira/Ubatuba), foram considerados como coincidentes as cotas, e horários das variações maregráficas na área de levantamento.

\subsection{Sistema de Modelagem Costeira}

Para os dados de onda foi utilizado o Sistema de Modelagem Costeira (SMC). Os dados de batimetria foram retirados das cartas náuticas referentes à costa do Brasil disponíveis na base de dados desse sistema de modelagem.

O Sistema de Modelagem Costeira (SMC) é uma ferramenta computacional que agrega uma série de modelos numéricos, estruturados de acordo com as escalas temporais e espaciais dos processos a modelar. Este conjunto de programas permite gerar diferentes cenários na região costeira, como instrumento de avaliação na identificação de como o sistema responde às diferentes forçantes que o controlam como o regime de ondas, transporte sedimentar litorâneo, influência das obras de engenharia costeira, entre outros. O Sistema de Monitoramento Costeiro (SMC) foi desenvolvido pelo Grupo da Universidade de Cantábria, sob a orientação do Governo da Espanha, através do Ministério correspondente ao Ministério do Meio Ambiente do Brasil. 
Para a construção da base de dados de ondas do IH Cantabria foi utilizada uma única batimetria, obtida através da união da batimetria global "General Bathymetric Chart of the Oceans" (GEBCO) junto às cartas náuticas do litoral brasileiro, disponíveis na base de dados do Sistema de Modelado Costeiro - Brasil. A batimetria GEBCO é uma batimetria global com resolução de 0,5 minutos, disponível no Britsh Oceanographyc Data Centre (BDOC), que foi construída a partir da combinação de dados procedentes de levantamentos hidrográficos e satélite. A base de dados de ondas para toda a costa de Brasil, pertencente ao IH Cantábria, foi construída através de uma reanálise de ondas que se denomina Global Ocean Waves (GOW) e o modelo numérico utilizado para a simulação da reanálise de ondas foi o modelo WaveWatch III Tolman 1997, 1999 desenvolvido pela NOAA/NCEP in De Luca,2011.

Os dados de pressão e vento foram utilizados pelo IH Cantabria para a construção da base de dados de reanálises de maré meteorológica e de ondas, séries estas, utilizadas nesse trabalho. Os dados foram obtidos do Projeto de Reanálises NCEP/NCAR da Physical Scienses Division (NOAA/ESRL) devido sua cobertura global, sua resolução espacial, e alcance temporal que esses dados atmosféricos proporcionam. Os dados cobrem um período de 1948 até a atualidade, sendo um produto periodicamente atualizado (De Luca, 2011).

O modelo assume como hipótese fundamental que as propriedades do meio (correntes e batimetria) e o campo de ondas variam em escalas muito maiores que um comprimento de onda, tanto no espaço quanto no tempo. A partir dessa informação, se assume como limitante do modelo, que este não seja capaz de simular os efeitos da propagação das ondas em menores profundidades tão eficazmente como outros modelos. E é por este motivo que se utiliza o modelo SWAN (Simulating Waves Nearshore) para realizar as propagações desde pontos obtidos pela base de dados GOW, 
até zonas de águas costeiras localizadas frente ao litoral brasileiro, tomando como condições iniciais de simulação os resultados do modelo WaveWatch III (De Luca,2011).

O modelo SWAN está fundamentado na conservação da ação espectral da onda, mas não é capaz de resolver de maneira efetiva os fenômenos de difração que afetam as ondas que chegam até a costa; e é a partir desse ponto que se faz o transporte destas ondas até pontos localizados na costa com modelo OLUCA, modelo este, incluído no Sistema de Modelado Costeiro -Brasil (De Luca,2011).

Base de dados gerada por modelos numéricos de reanálise e pela previsão de variáveis oceanográficas, como os dados da reanálise GOW, proporcionam dados divididos espaçados de forma relativamente estruturada e constituem registros temporais que abrangem parâmetros de estados de mar dentro de um longo período, com intervalos regulares e de ordem de duração de uma hora. Estes dados, por sua vez, são suficientemente adequados para a caracterização de fenômenos climáticos e oceanográficos (De Luca,2011).

A propagação realizada nesse estudo utilizou os modelos SWAN (Simulating Waves Nearshore, desenvolvido por Delf University of Technology) e OLUCA-SP (Modelo parabólico de propagação de ondas espectrais do Grupo de Engenharia Oceanográfica e de Costas da Universidade de Cantabria, que será chamado neste trabalho como OLUCA), através da aplicação S2O (Swan to Oluca), desenvolvida pelo Grupo de Engenharia Oceanográfica e de Costas da Universidade de Cantabria (De Luca, 2011).

Dessa forma, o SWAN resolve a refração e o empinamento satisfatoriamente, enquanto que o OLUCA é capaz de simular, além desses processos, a difração. Visto de 
outra forma, o OLUCA requer uma determinada resolução espacial por comprimento de onda, na qual se faz inviável sua utilização para propagações em grandes domínios, onde o SWAN é altamente eficiente. No entanto, essa eficiência é limitada pelas propagações que chegam até zonas de águas mais rasas, quando a difração começa a tomar maiores proporções, como um processo de transformação das ondas (De Luca, 2011).

\subsection{Levantamentos topográficos}

Os levantamentos topográficos foram realizados entre Junho e Agosto de 2012. Neste período foram monitorados três setores praiais, um em cada praia estudada, com malhas de caminhamento como apresentado na figura 5.

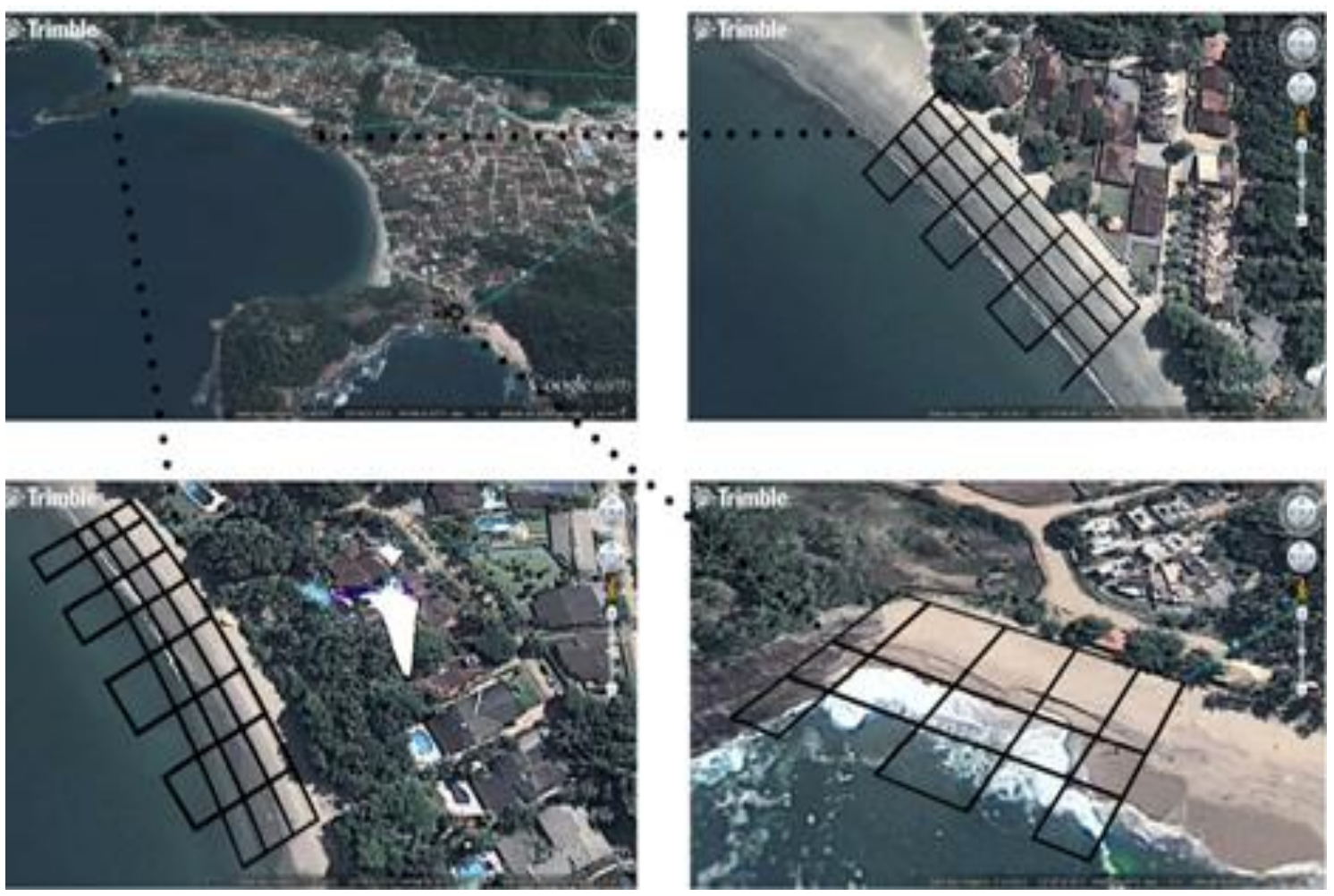

Figura 5 Foto das áreas amostradas (Google Earth) 
Para a execução dos levantamentos topográficos (topografia de precisão) foi empregado um sistema de posicionamento geográfico em modo diferencial (DGPS).

O sistema DGPS funciona usando um GPS como base (estático), fixado em um ponto de coordenadas conhecidas e outro colocado em movimento sobre pontos cujas coordenadas deseja-se determinar (NASCIMENTO, 2009).

O GPS L1 no modo diferencial (DGPS) é a configuração mais apropriada para o estudo da morfologia da praia porque mostra um nível aceitável de precisão variando de 1 a 2 centímetros (Gilli et al., 2000).

Segundo Freitas et.al (2006), o método empregado apresenta uma distância vertical média entre pontos cotados de $12 \mathrm{~cm}$ entre os valores obtidos com o emprego do teodolito e os obtidos pelos levantamentos DGPS. No cálculo de volume tais diferenças são relativamente pequenas, considerando o volume total dos envelopes calculados para cada perfil de levantamento. Assim, pode-se inferir que o método de DGPS (L1) corresponde a um método de levantamento adequado para investigação das variabilidades morfológicas nas escalas temporais e espaciais correspondentes aos períodos de levantamentos para as praias da enseada da Fortaleza.

Os levantamentos foram realizados com o aparelho DGPS da marca Trimble, sendo a base fixa constituída pelo receptor L200 e antena Zephir e a estação móvel constituída pelo receptor R3 e antena A3. Durante os levantamentos foram utilizadas a configuração PPK (Pos Processed Kinematic) do aparelho, na qual os dados de ambas as estações são coletados de forma independente e são processados posteriormente.

A estação fixa inicialmente estava localizada no ponto fixo construído na Base de Pesquisa "Clarimundo de Jesus", situada na cidade de Ubatuba com coordenada $23^{\circ} 30^{\prime} 00.62820^{\prime \prime} \mathrm{S}$ e $45^{\circ} 07^{\prime} 08.05567^{\prime \prime} \mathrm{W}$. Posteriormente a isso, sentiu-se a necessidade da mudança da localização do receptor fixo para melhor precisão dos resultados. 
Foi escolhido um ponto no condomínio Pedra Verde, localizado na Praia do Lázaro, em frente à praia, com coordenada $23^{\circ} 30^{\prime} 02.14961^{\prime}$ 'S E $45^{\circ} 08^{\prime} 20.41346^{\prime \prime} \mathrm{W}$.

Os dados foram coletados por meio de um caminhamento contínuo, tentando produzir uma malha amostral que englobasse a maior área do prisma praial em face da variação de maré. A forma que mais se adequou foi a de perfis transversais separados por distâncias de 18 metros (condicionadas em função das variações morfológicas da praia) cortados por um perfil contínuo longitudinal que acompanhou a interface entre a areia seca e a areia molhada, uma acompanhando quando existentes, as cúspides praiais e uma junto ao pós-praia. Os perfis transversais variaram entre o limite superior da face praial, na maioria das áreas contidas por um muro (verificando as limitações de sinal por consequência da cobertura de árvores), e a máxima profundidade na área submersa onde se pode caminhar com o equipamento em segurança.

Os dados do levantamento topográfico (DGPS) gerados em campo foram referenciados para o datum WGS84 global e tratados com o programa Trimble Business Center, que gerou coordenadas geográficas (latitude, longitude e altura altimétrica), processadas com a tolerância vertical de $0,020 \mathrm{~m}$ e horizontal de $0,050 \mathrm{~m}$.

Mudanças de volume na superfície da praia foram calculadas utilizando o interpolador de 'vizinho natural', que não extrapola valores, resolvendo a interpolação somente para o interior do domínio de dados (Mazzini, 2009), de maneira linear. O software utilizado para este cálculo foi Surfer, versão 8 (Golden Software ${ }^{\circledR}$ ), gerando um Modelo Digital do Terreno. 
4.5. Coleta e análise de sedimentos praias

Foram coletadas amostras de sedimentos junto à linha d'água, simultaneamente ao levantamento topográfico, armazenadas em sacos plásticos e etiquetadas. As amostras coletadas foram processadas e analisadas em laboratório, utilizando- se a metodologia estabelecida em Suguio (1992).

As amostras foram secas em estufa a $60^{\circ}$ por 24 horas. Em balança de precisão foram pesadas cerca 30 gramas(g), para peneiramento em agitador mecânico (Bronzinox). As amostras foram peneiradas e separadas em intervalos de peneiras com diâmetro de $2 \mathrm{~mm}, 1 \mathrm{~mm}, 0,710 \mathrm{~mm}, 0,5 \mathrm{~mm}, 0,354 \mathrm{~mm}, 0,250 \mathrm{~mm}, 0,177 \mathrm{~mm}, 0,125 \mathrm{~mm}$, 0,088mm e 0,063mm referentes à escala de 1922 de Wentworth (Suguio,1992).

Os dados foram tratados estatisticamente em um software de computador específico, o Sistema de Análise Granulométrica - LABSED (LABSED/IOUSP), sendo a classificação textural baseada na escala de Folk e Ward (1968 in SUGUIO,1992). O programa gerou tabelas que foram plotadas em EXCEL. 


\section{Resultados}

Os campos no litoral de Ubatuba foram realizados no período de Junho à Agosto de 2012.

Os levantamentos correspondem aos dias 19, 20, 21, 22 e 23 de Junho, 08, 09, 10, 11, 12 e 13 de Julho e 28, 29, 30 e 31 de Agosto, resultando em um período total amostrado de dois meses e meio (18 de junho à 31 de agosto) (Tabela 1).

Tabela 1 Dias amostrados para o ano de 2012.

\begin{tabular}{|c|c|c|c|}
\cline { 2 - 4 } \multicolumn{1}{c|}{} & Junho & Julho & agosto \\
\hline \multirow{4}{*}{ Dias } & 19 & 8 & 28 \\
\cline { 2 - 4 } & 20 & 9 & 29 \\
\cline { 2 - 4 } & 21 & 10 & 30 \\
\cline { 2 - 4 } & 22 & 11 & 31 \\
\cline { 2 - 4 } & 23 & 12 & \\
\cline { 2 - 4 } & & 13 & \\
\hline
\end{tabular}

5.1. Condições climáticas ao longo do período amostrado

De acordo com as análises obtidas do INPE(2012) o ano de 2012 correspondeu a um período de predomínio do episódio, El Niño/Oscilação Sul (ENOS).

El Niño é um fenômeno atmosférico-oceânico caracterizado por um aquecimento anormal das águas superficiais no oceano Pacífico Tropical, e pode afetar o clima regional e global, mudando os padrões de vento a nível mundial, e afetando assim, os regimes de chuva em regiões tropicais e de latitudes média.

Este processo tem como característica a geração de um comportamento anômalo para os sistemas atmosféricos que atuam sobre o Brasil, criando um bloqueio à entrada de frentes frias. 
As anomalias ocasionadas pelo ENOS permite estabelecer um 'padrão do seu comportamento, que também esta relacionado com a intensidade com que o fenômeno ocorre (MARTINS,2000).

No verão, de maneira geral, ocorre enfraquecimento da Zona de Convergência Intertropical (ZCIT), que não se desloca para sul, somado ao enfraquecimento da convecção associada à Alta Bolívia e da Zona de Convergência do Atlântico Sul, resultando no enfraquecimento da precipitação. Entretanto, no inverno, grande parte dos sistemas frontais não consegue se deslocar para o norte, achando-se intensificados na Região Sul do Brasil, o que ocasiona aumento de pluviosidade nesta região, ocorrendo chuvas acima da média, seguido por maior aquecimento na região sudeste, associado às baixas precipitações, que apresentam desvios negativos com relação às médias (CAVALCANTI,1997; MARTINS,2000)

A evolução típica do fenômeno ENOS mostra que ele se inicia no começo do ano, atinge sua máxima intensidade durante dezembro do ano em que se formou e janeiro do ano seguinte e se enfraquece na metade do segundo ano. (MARTINS,2000).

No período em que se realizou o monitoramento das praias de Ubatuba foi observado no mês de junho uma anomalia média nas águas superficiais entre $1^{\circ} \mathrm{C}$ e $2^{\circ} \mathrm{C}$ no setor leste do Pacífico Equatorial, na região conhecida como Niño 1+2. O Brasil continuou apresentando déficit de chuva no norte e nordeste do Brasil. O mês de Julho foi marcado pela diminuição das chuvas no sul das Regiões Sudeste e Centro-Oeste e no Paraná, em comparação com junho passado. O fenômeno El Niño continuou evoluindo no setor central do Pacífico Equatorial, porém notou-se uma ligeira diminuição das anomalias positivas de temperatura da superfície do mar próximo à costa oeste da América do Sul. As oscilações intra-sazonais voltaram a influenciar as chuvas em parte 
da Região Sudeste, sendo notado o início da fase desfavorável à ocorrência de chuvas entre final de julho e início de agosto. Durante o mês de agosto, a atuação de um sistema de alta pressão anômalo adjacente à costa sudeste da América do Sul contribuiu para a escassez de chuva, na maior parte do Brasil. No entanto, este mesmo sistema favoreceu a ocorrência de chuvas na faixa litorânea das Regiões Nordeste e Sudeste do Brasil (CPTEC/INPE,jul 2012; CPTEC/INPE,ago 2012; CPTEC/INPE, set 2012).

Ainda segundo CPTEC/INPE, o fenômeno El Niño em comparação com julho de 2011, favoreceu o deslocamento para oeste das anomalias positivas de Temperatura da Superfície do Mar (TSM), que aumentaram na América do Norte e diminuíram próximo à costa oeste da América do Sul.

Durante os meses estudados, a maior ocorrência de chuvas foi consecutivamente o mês de Julho, Junho e Agosto (Tab. 2).

Para a campanha de Julho foi possível constatar o pico de $79,25 \mathrm{~mm}$ de chuva no dia 9 de Junho (Fig.6), um pico menor, de 79,25 mm, no dia 19 de Julho (Fig.7) e um de 10,41 $\mathrm{mm}$ no dia 1 de agosto (Fig.8).

As temperaturas para o período estudado obtiveram uma média geral de $20^{\circ} \mathrm{C}$, com a menor temperatura de $17,51{ }^{\circ} \mathrm{C}$ no dia 8 de Julho e a maior $22,65{ }^{\circ} \mathrm{C}$, no dia 31 de Agosto (Tab. 3).

A pressão atmosférica durante o período estudado (Fig.9) apresentou uma média de 1014 mbar. O mês de junho apresentou os menores valores de pressão atmosférica enquanto o mês de Agosto os valores mais altos, se correlacionando bem com os dados de temperatura média do ar e das passagens das frentes frias durante o período estudado. 
Tabela 2 Tabela das precipitações nos dias de coleta para a cidade de Ubatuba-SP no ano de 2012 (IOUSP/Base Norte,2012).

\begin{tabular}{|c|c|c|}
\hline \multicolumn{2}{|c|}{2012} \\
\hline Mês & Dia & Precipitação (mm) \\
\hline \multirow{4}{*}{ Junho } & 19 & 0,00 \\
& 20 & 1,27 \\
& 21 & 18,54 \\
& 22 & 2,54 \\
& 23 & 5,08 \\
\hline \multirow{4}{*}{ julho } & 8 & 0,00 \\
& 9 & 29,21 \\
& 10 & 0,76 \\
& 11 & 0,00 \\
& 12 & 0,00 \\
& 13 & 6,10 \\
\hline \multirow{5}{*}{ Agosto } & 27 & 0,00 \\
& 28 & 3,30 \\
& 29 & 8,13 \\
& 30 & 0,25 \\
\hline
\end{tabular}

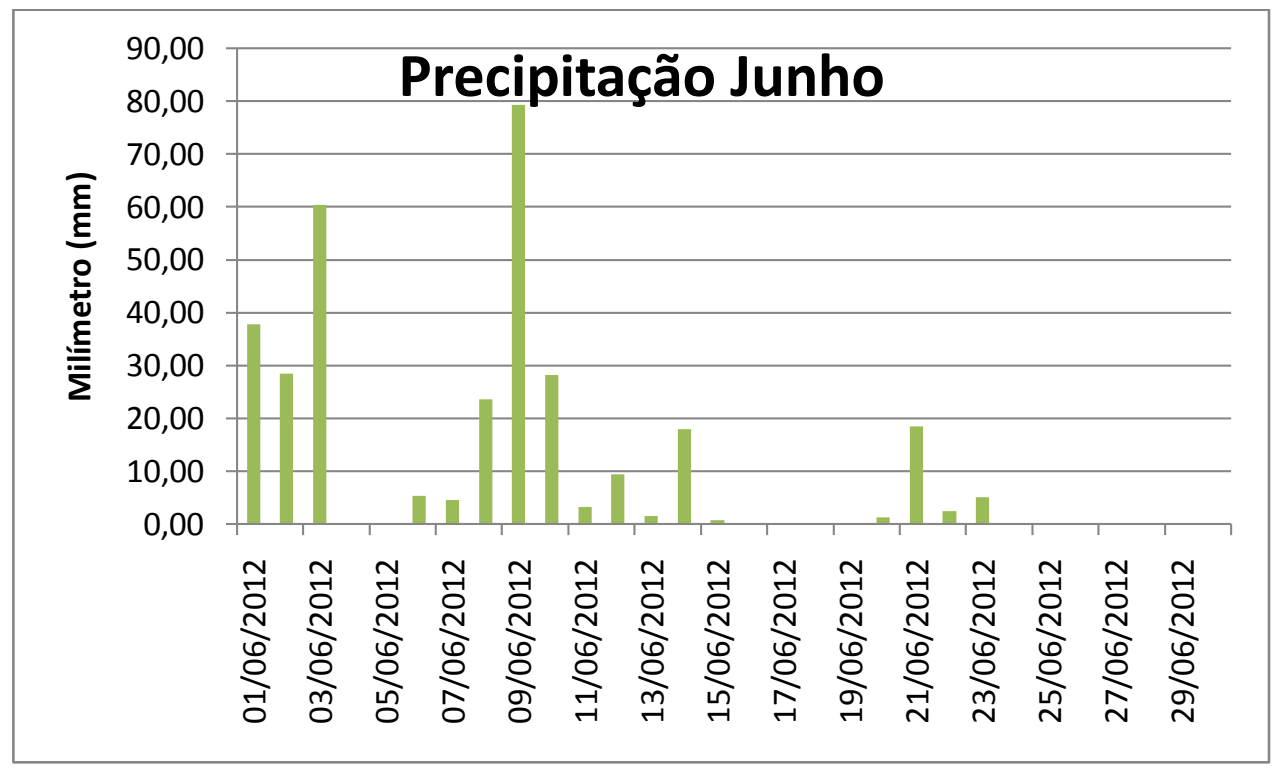

Figura 6 Gráfico das precipitações em junho de 2012 na cidade de Ubatuba-SP (IOUSP/Base Norte,2012). 


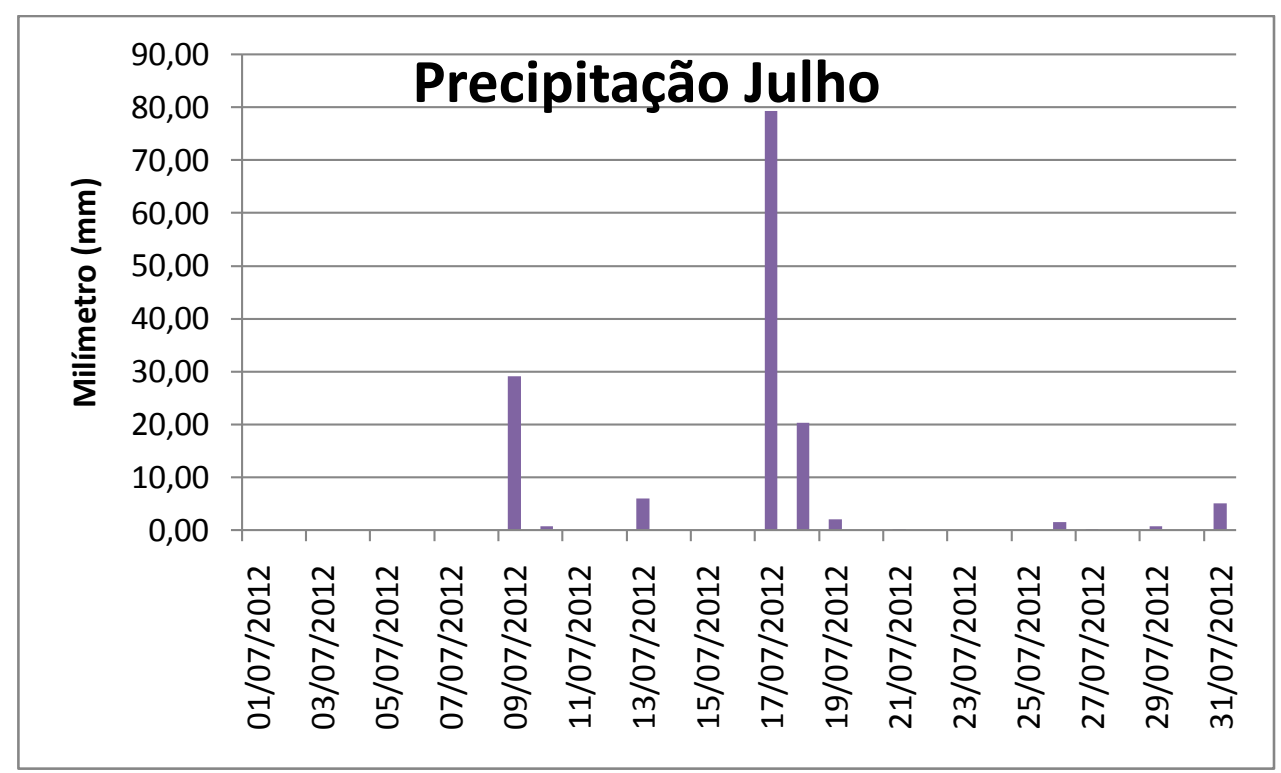

Figura 7 Gráfico das precipitações no mês de Julho de 2012 para a cidade de Ubatuba -SP (IOUSP/Base Norte,2012).

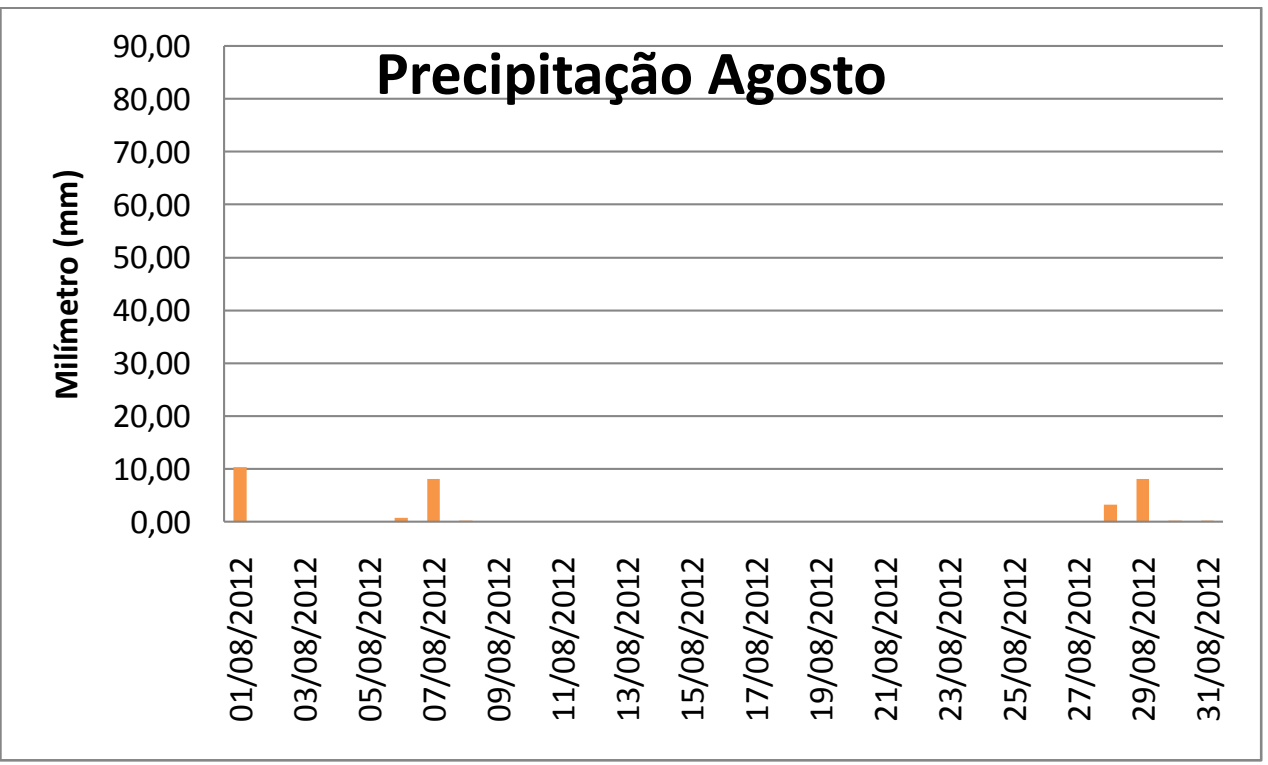

Figura 8 Gráfico das precipitações no mês de Agosto de 2012 para a cidade de Ubatuba -SP (IOUSP/Base Norte,2012). 
Tabela 3 Tabela da temperatura média para os meses estudados na região de Ubatuba- SP no ano de 2012 (IOUSP/Base Norte,2012).

\begin{tabular}{|c|c|c|}
\hline \multirow{4}{*}{ Mês } & \multicolumn{2}{|c|}{2012} \\
\hline \multirow{5}{*}{ Junho } & Dia & Temperatura média $\left({ }^{\circ} \mathbf{C}\right)$ \\
\hline & 18 & 20,89 \\
& 19 & 22,07 \\
& 20 & 20,18 \\
& 21 & 19,87 \\
& 22 & 21,24 \\
& 23 & 19,56 \\
\hline \multirow{5}{*}{ Julho } & 8 & 17,51 \\
& 9 & 17,71 \\
& 10 & 17,74 \\
& 11 & 21,13 \\
& 12 & 19,67 \\
& 13 & 18,73 \\
\hline \multirow{5}{*}{ Agosto } & 27 & 20,72 \\
& 28 & 20,76 \\
& 29 & 20,98 \\
& 30 & 21,82 \\
& 31 & 22,63 \\
\hline
\end{tabular}

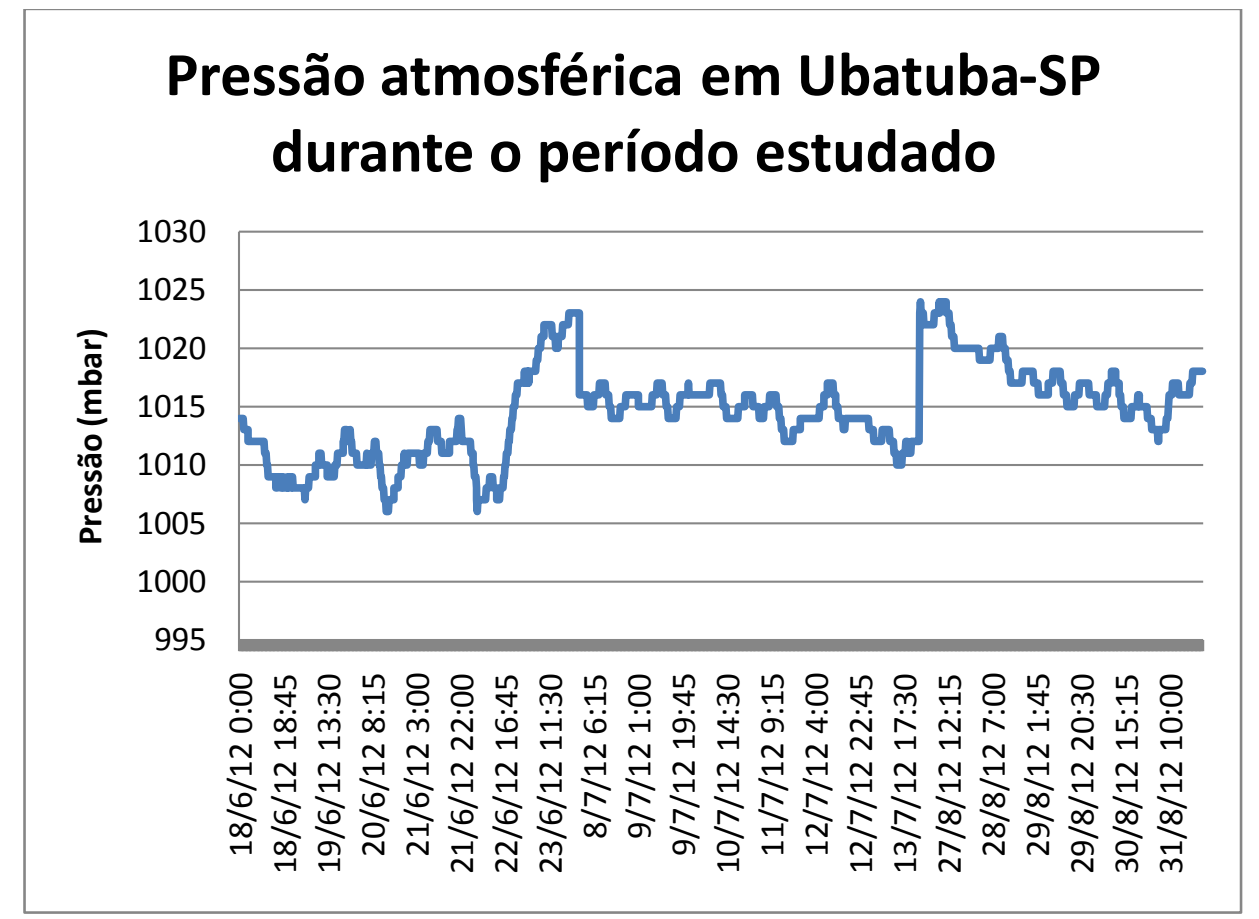

Figura 9 Gráfico da pressão atmosférica durante os meses estudados para a cidade de Ubatuba-SP no ano 2012 para a cidade de Ubatuba -SP (IOUSP/Base Norte,2012). 
As cartas sinóticas dos dias 18 a 23 de junho foram a base para identificação dos sistemas frontais que atuaram na região durante o período estudado (fig.10).

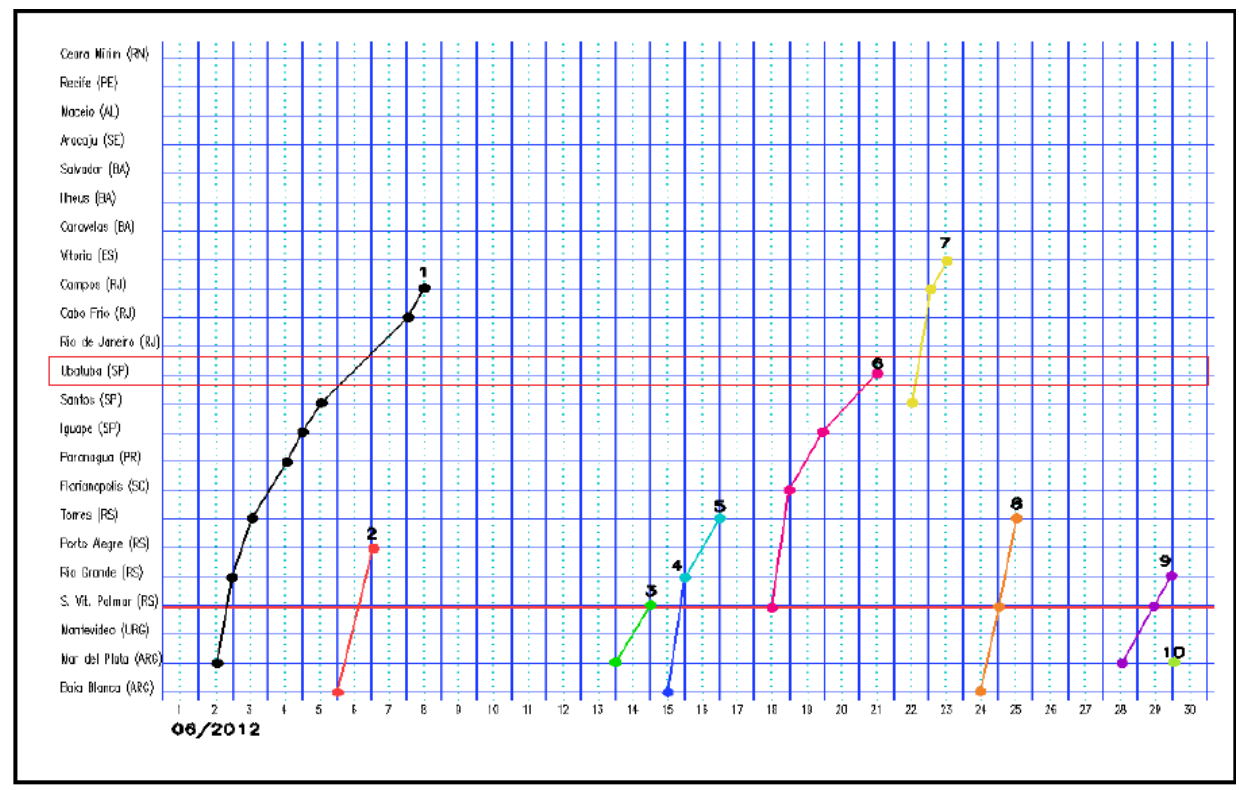

Figura 10 : Acompanhamento das frentes frias ao longo do mês de Junho de 2012 (CPTEC/INPE,2002)

Durante o mês de Junho uma frente fria começou a se estabelecer, deixando a região Charlie, no dia 18 de junho às 12 horas, com forte influência de três centros de baixa pressão (1000, 1006 e 1006 HPA) caracterizando um período pré-frontal. A frente avançou e se estabilizou na região, com pressão local de 1002 HPA, no dia 19 de Junho com um núcleo de baixa pressão de 996 HPA e ondulação de S. A frente avançava lentamente sobre a região, sofrendo uma forte influência de três núcleos de alta pressão (1016, 1030, 1034 HPA), caracterizando-a como uma frente quase estacionária (Fig 11, 12 e 13 ). Esse tipo de instabilidade costuma ser mais frequente em meses de primaveraverão (NIMER,1989). No dia 21 a frente começou a se afastar deixando condições de pós-frontal (1016 HPA), com ondulação de E e NE. Durante os dias 22 e 23 de junho 
predominou tempo bom, com influência do centro de alta pressão (1022 HPA) (Diretoria de Hidrografia e Navegação/DHN- cartas sinóticas jun/2012).

Para esse mês foi possível observar todo o avanço do sistema frontal, desde o período de pré-frontal, até o de pós-frontal como observado na figura 11,12 e 13. 


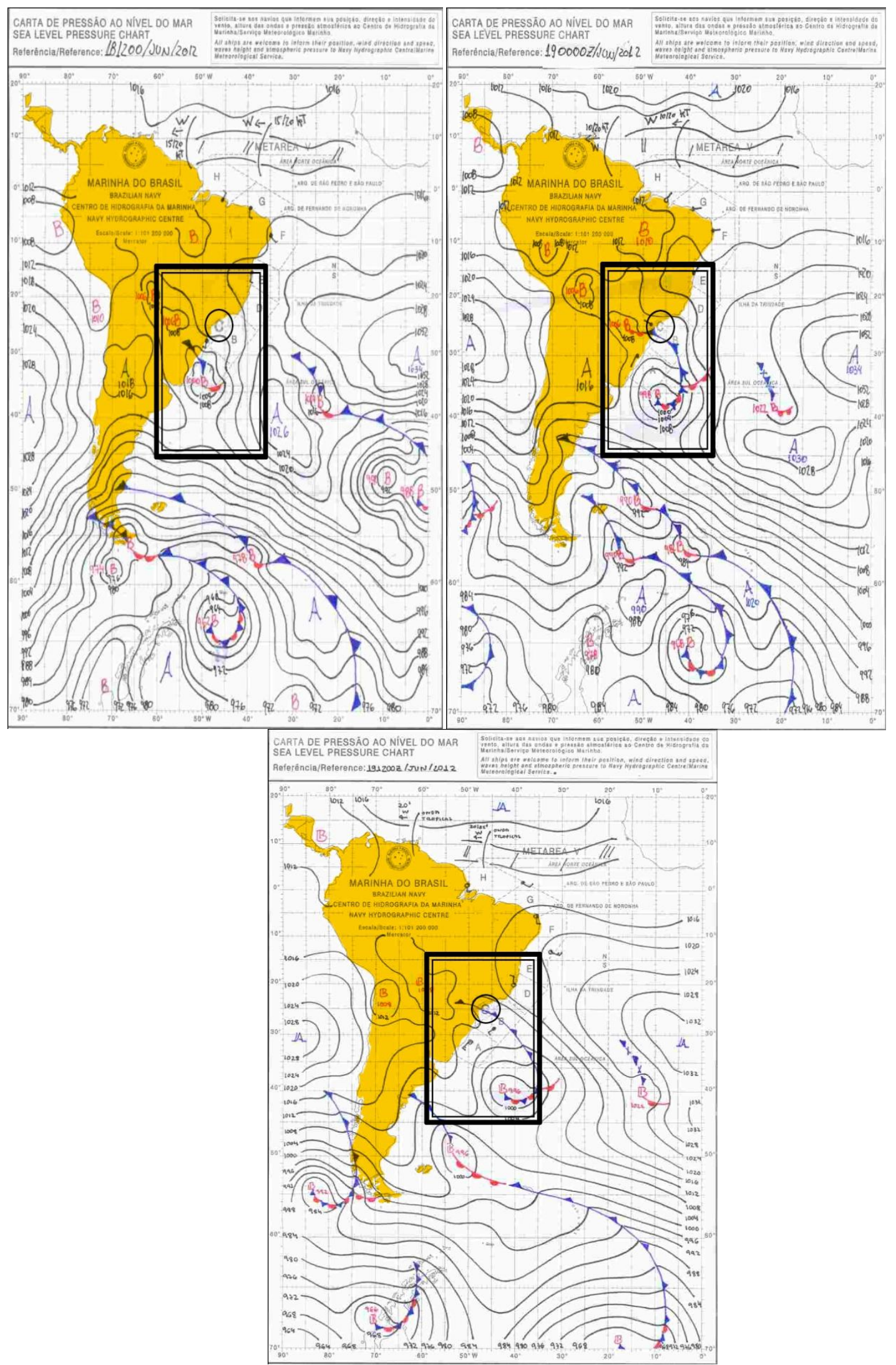

Figura 11 Acompanhamento do centro de baixa pressão na carta sinótica dos dias 18 à 22 de junho de 2012 sobre a região de Ubatuba-SP (Parte 1). 


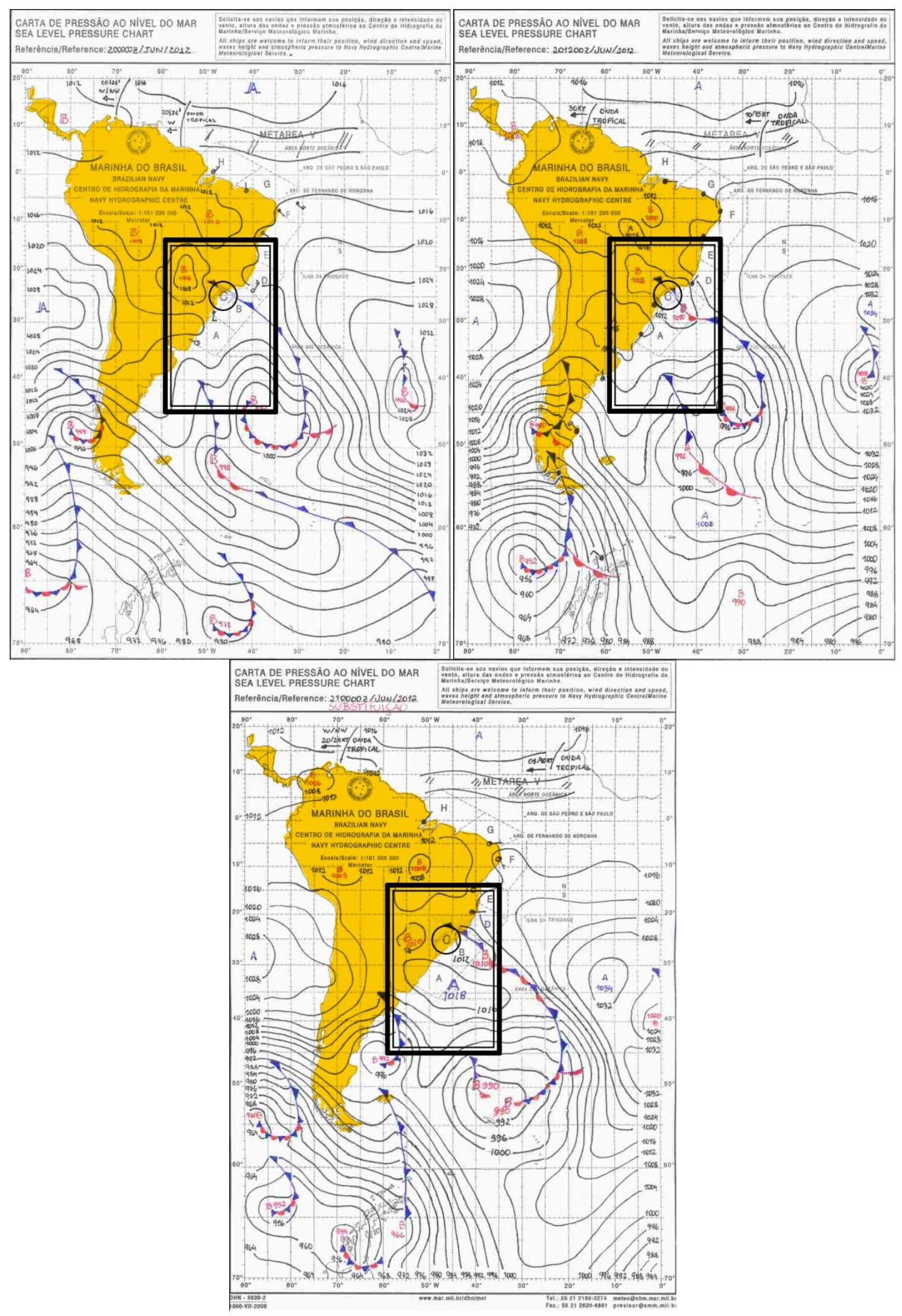

Figura 12 Acompanhamento do centro de baixa pressão na carta sinótica dos dias 18 à 22 de junho de 2012 sobre a região de Ubatuba-SP (Parte 2). 


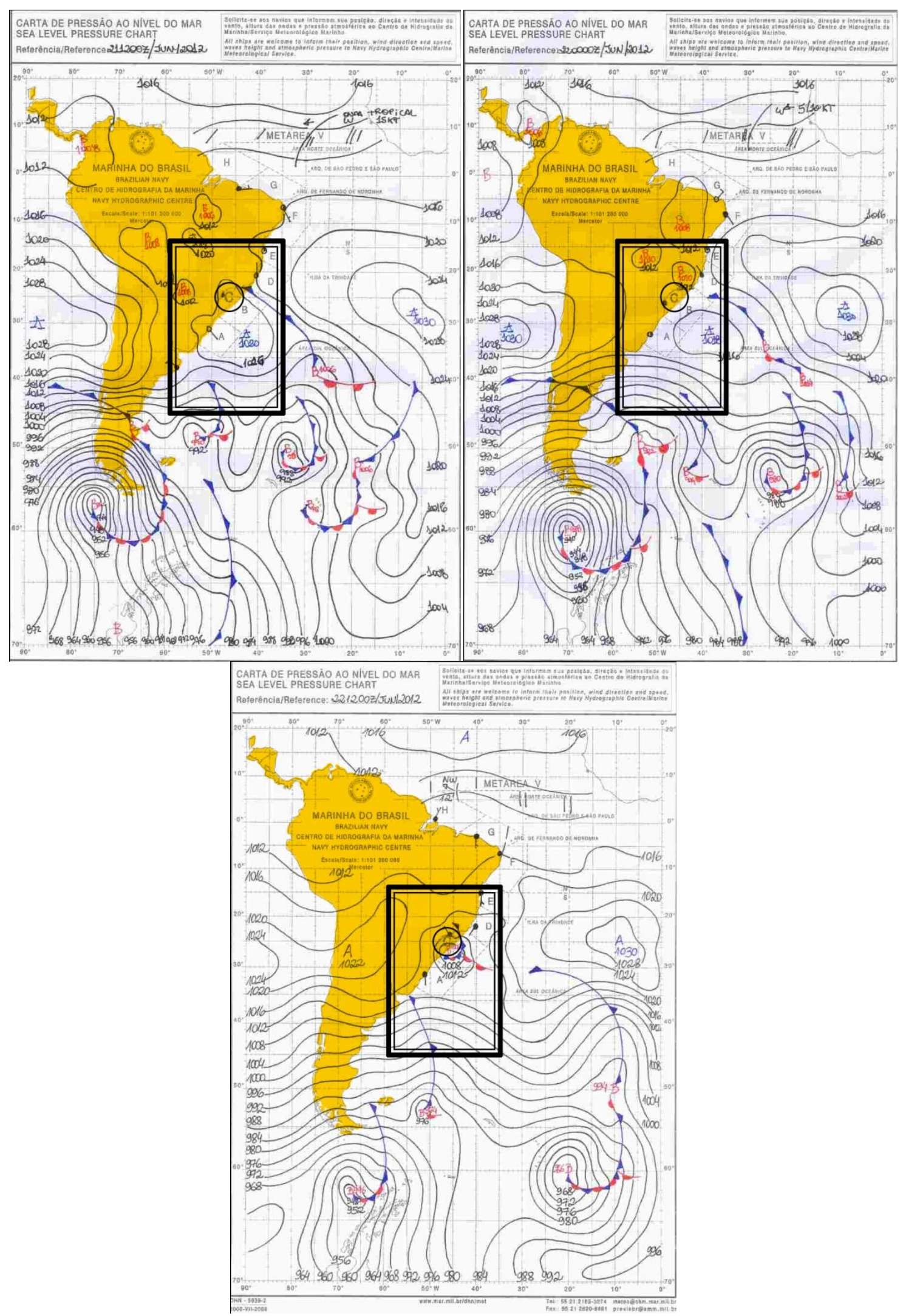

Figura 13 Acompanhamento do centro de baixa pressão na carta sinótica dos dias 18 à 22 de junho de 2012 sobre a região de Ubatuba-SP (Parte 3). 
No período de 08 a 13 de julho, ocorreu a passagem de dois sistemas frontais, um de baixa intensidade e o segundo de maior intensidade, que perdeu força não atingindo a região (Fig 14).

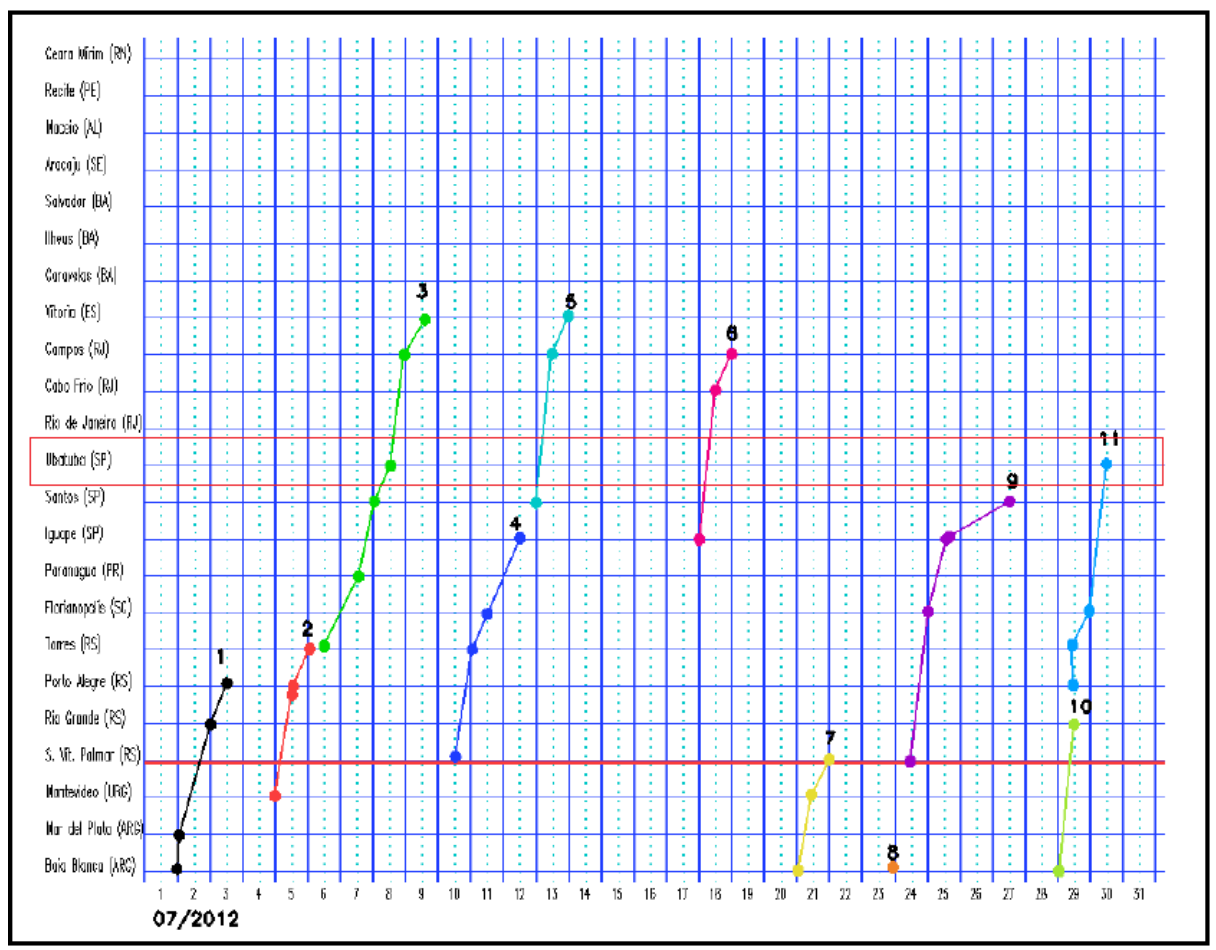

Figura 14: Acompanhamento das frentes frias ao longo do mês de Julho de 2012 (CPTEC/INPE,2012)

No primeiro dia de campo, 08 de julho, as condições apresentadas na região Charlie da carta sinótica das 12 horas, eram típicas de pós-frontal com forte influência de um centro de alta pressão (1028 HPA) e ondulação de E. Esse centro de alta pressão continuou mantendo a região com tempo estável (tempo bom) até o dia 11 de junho, quando um sistema frontal, com um núcleo de baixa pressão (998 HPA) com ondulação de S começa a se aproximar deixando a região com características pré-frontal. No dia 12 de julho na carta sinótica da 0 (zero) hora se estabeleceu uma frente fria com pressão de 994 HPA, sendo uma frente consideravelmente forte, com ondulação de Sul, que perdeu força não atingindo a região. Na carta de 12 horas do mesmo dia, a região novamente já 
apresentava características de pré-frontal. No dia 13 de julho notava-se o avanço de um novo sistema frontal, porém de baixa intensidade (1002 HPA) que passou rapidamente pois a carta sinótica das 12 horas do mesmo dia já apresentava novamente com tendência a tempo bom (Diretoria de Hidrografia e Navegação/DHN- cartas sinóticas jul/2012).

Para as cartas sinóticas de 27 a 31 de Agosto não ocorreu passagem de nenhum sistema frontal (Fig 15).

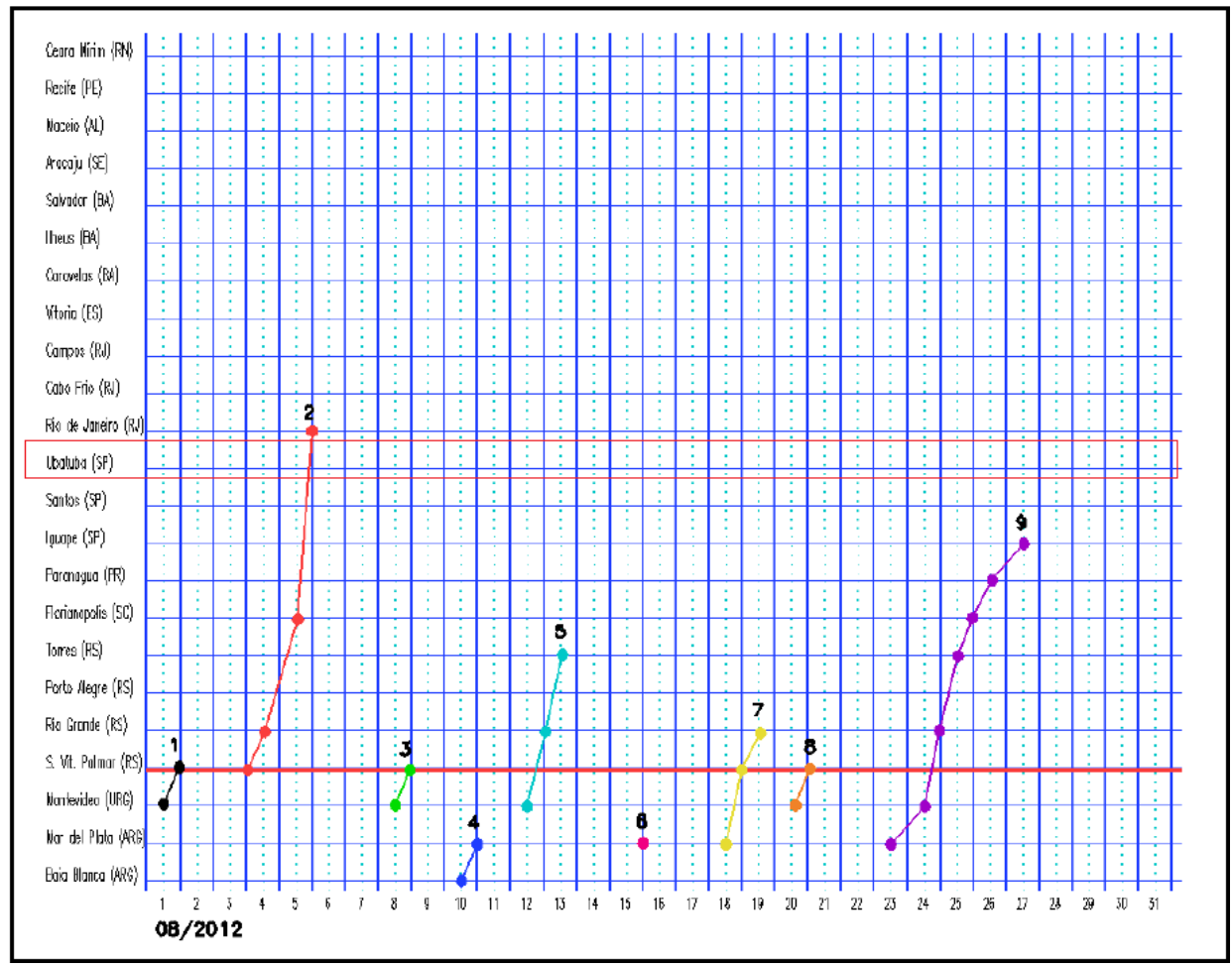

Figura 15 Acompanhamento das frentes frias ao longo do mês de agosto de 2012 (CPTEC/INPE,2012)

Para o dia 28 de Agosto observava-se condições de pré- frontal com pressão de 1024 HPA na região de estudo e influência de um centro de baixa pressão de intensidade fraca (1004 HPA) com aproximação de um centro de alta pressão com núcleo de 1028HPA, fazendo com que a frente perdesse força e não conseguisse chegar 
na área. De 29 a 31 de Agosto permaneceu com tempo bom, pressão local de 1020, sob influência de um centro de alta pressão (1034 HPA).

5.2. Condições maregráficas ao longo do período

O gráfico de Maré (Fig.16) representa os valores de marés registrados pelo marégrafo localizado na Base Norte do Instituto Oceanográfico da USP, nas datas e horários de realização dos perfis topográficos.

A variação da maré em Ubatuba é um regime de micro-maré. O valor máximo encontrado durante os meses estudados foi de 3,13 m no dia 8 de Julho e o mínimo, 1,51 m, no dia 30 de Agosto.

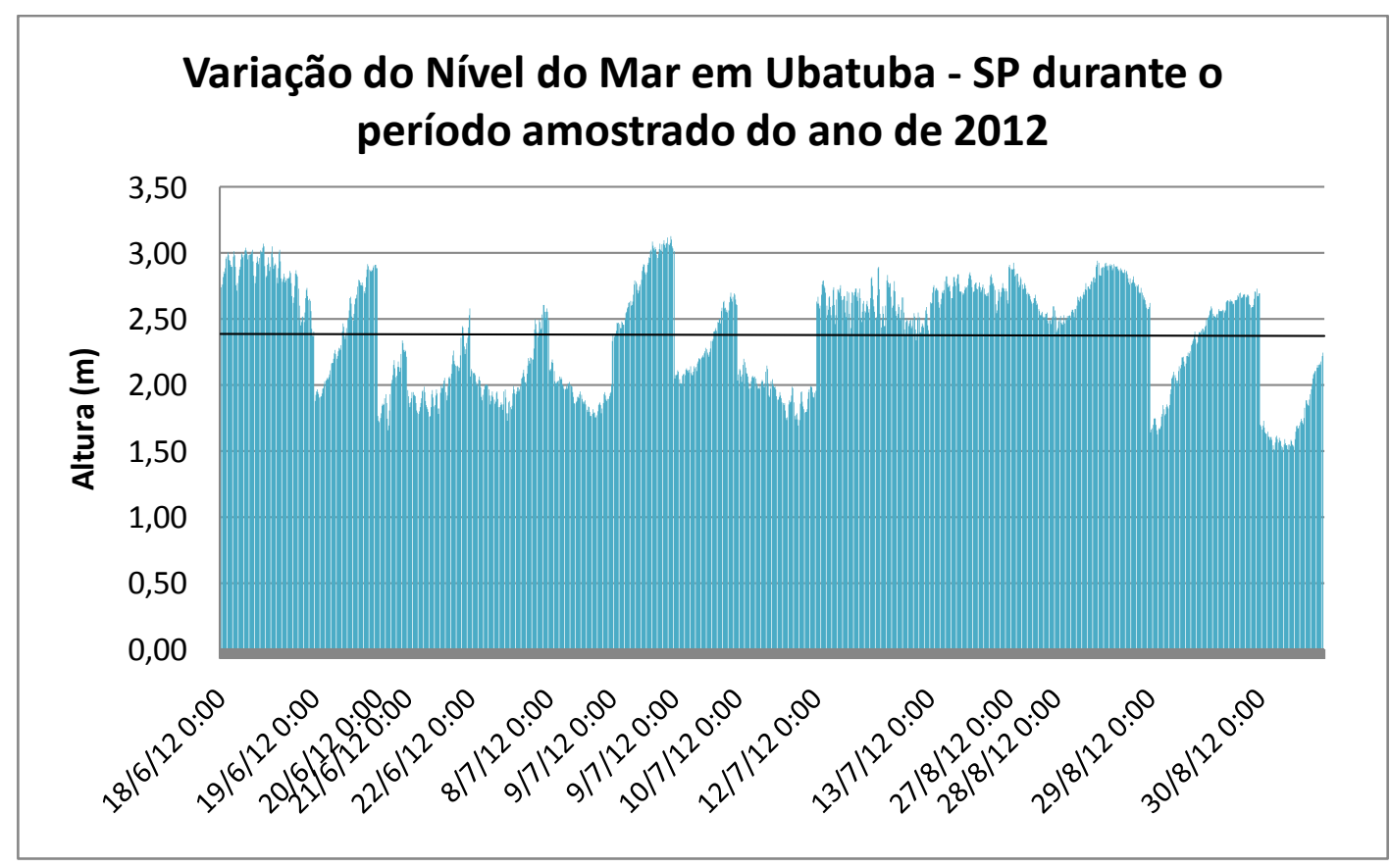

Figura 16 Variação do nível do Mar em Ubatuba - SP durante o período estudado do ano de 2012

5.3. Dados de ondas do Sistema de Modelagem Costeira (SMC)

Os dados de ondas de projeto na costa das praias estudadas foram definidos a partir de 50 anos de dados de um ponto down escolhido, conhecido para Enseada da 
Fortaleza. Esse ponto mostrou as principais incidências de ondas para a região e suas frequências (Fig 17). 0s resultados coincidem com o padrão já descrito para a região, de ondas provenientes do quadrante $\mathrm{SE}$, sendo que as ondas de SE são as com maiores freqüências e as de E são menores.

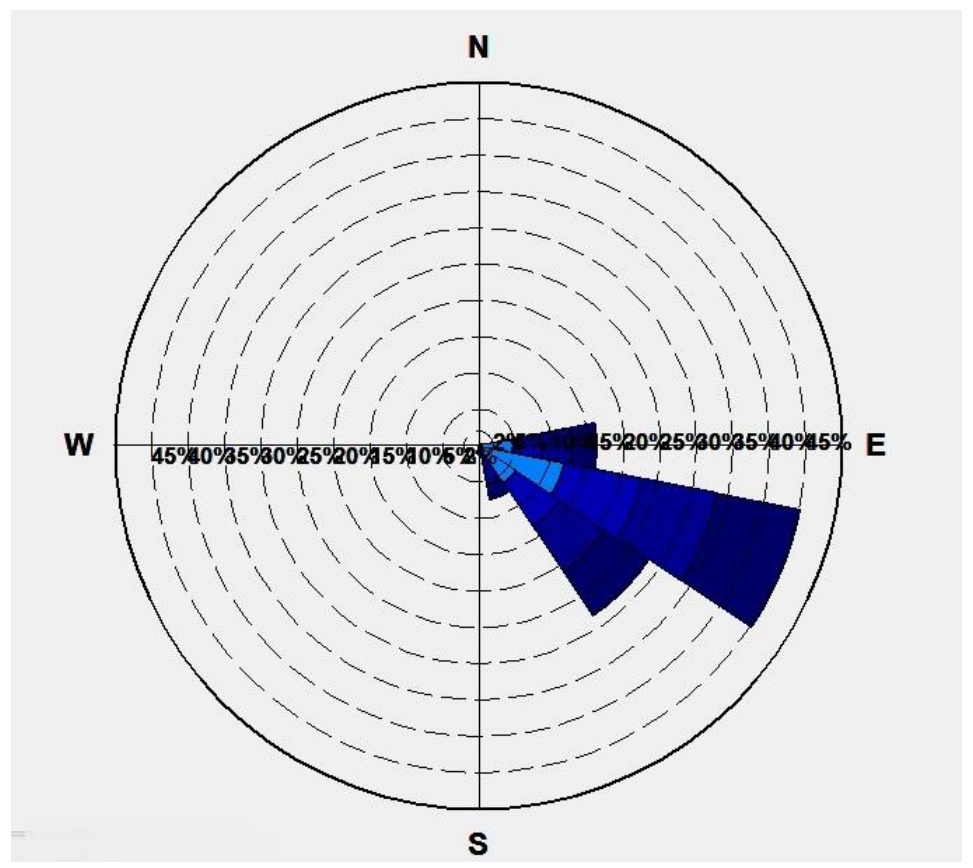

Figura 17 Incidências de ondas para a Enseada da Fortaleza (SMCBrasil,2013) 
A Figura 18 mostra uma baixa entrada de ondulação do quadrante Leste, que não apresentam correlação direta entre tamanho de onda e influencia no prisma praial, sendo escolhida uma altura média de 1 metro, sendo a Praia da Sununga a mais influenciada por essas ondas dentre as praias. Para a praia da Sununga as ondas do quadrante Sul, como mostrado nas figuras 19 e 20 continua sendo a mais importante entre elas, seguida pela Domingas Dias e pelo Lázaro. Em todas elas o canto oeste da praia é o mais afetado por essas ondulações, devido à orientações dos arcos praiais. 


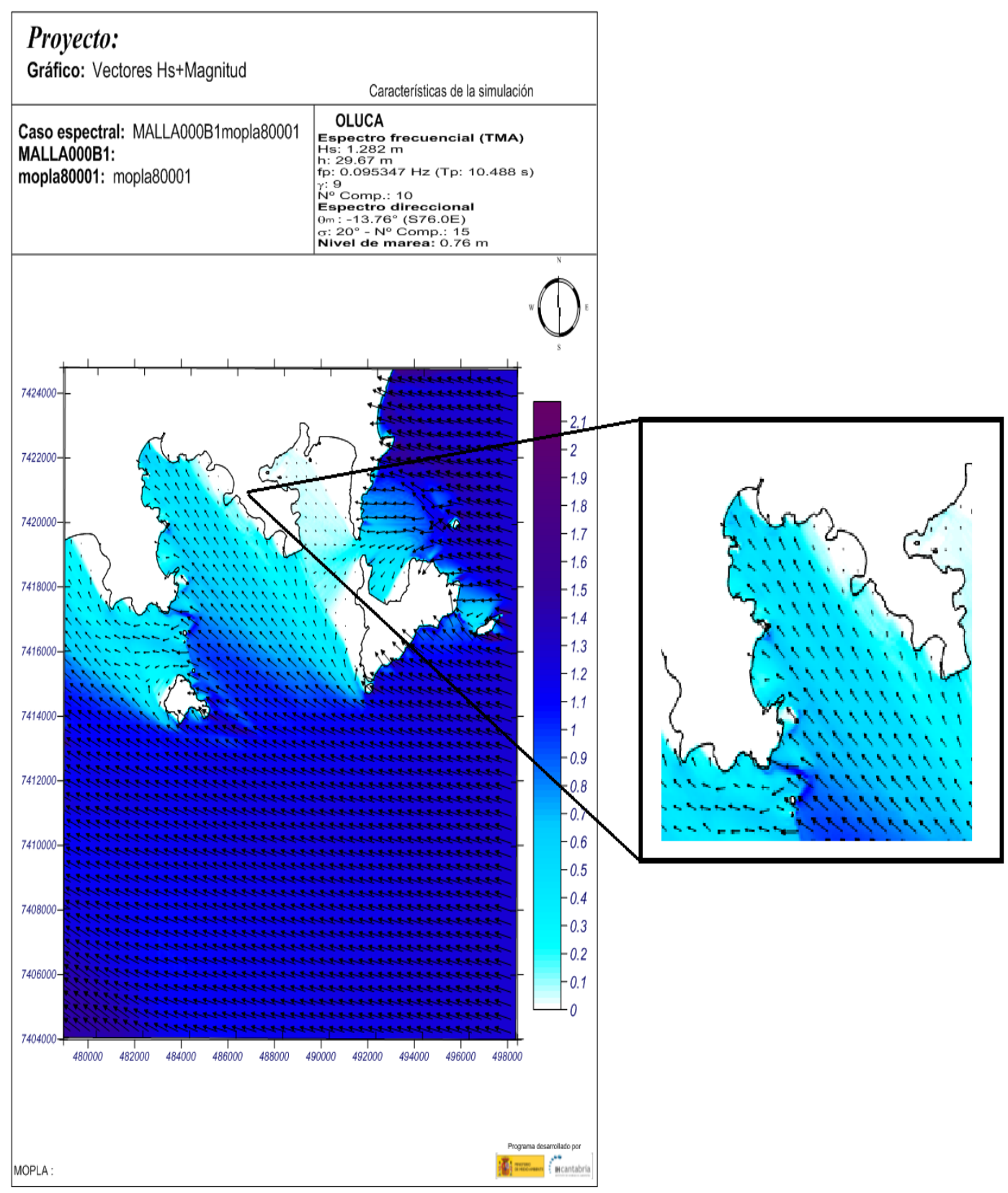

Figura 18 Simulação realizada pelo Sistema de Modelagem Costeira para ondas do quadrante Leste com altura de onda de 1 metro. 


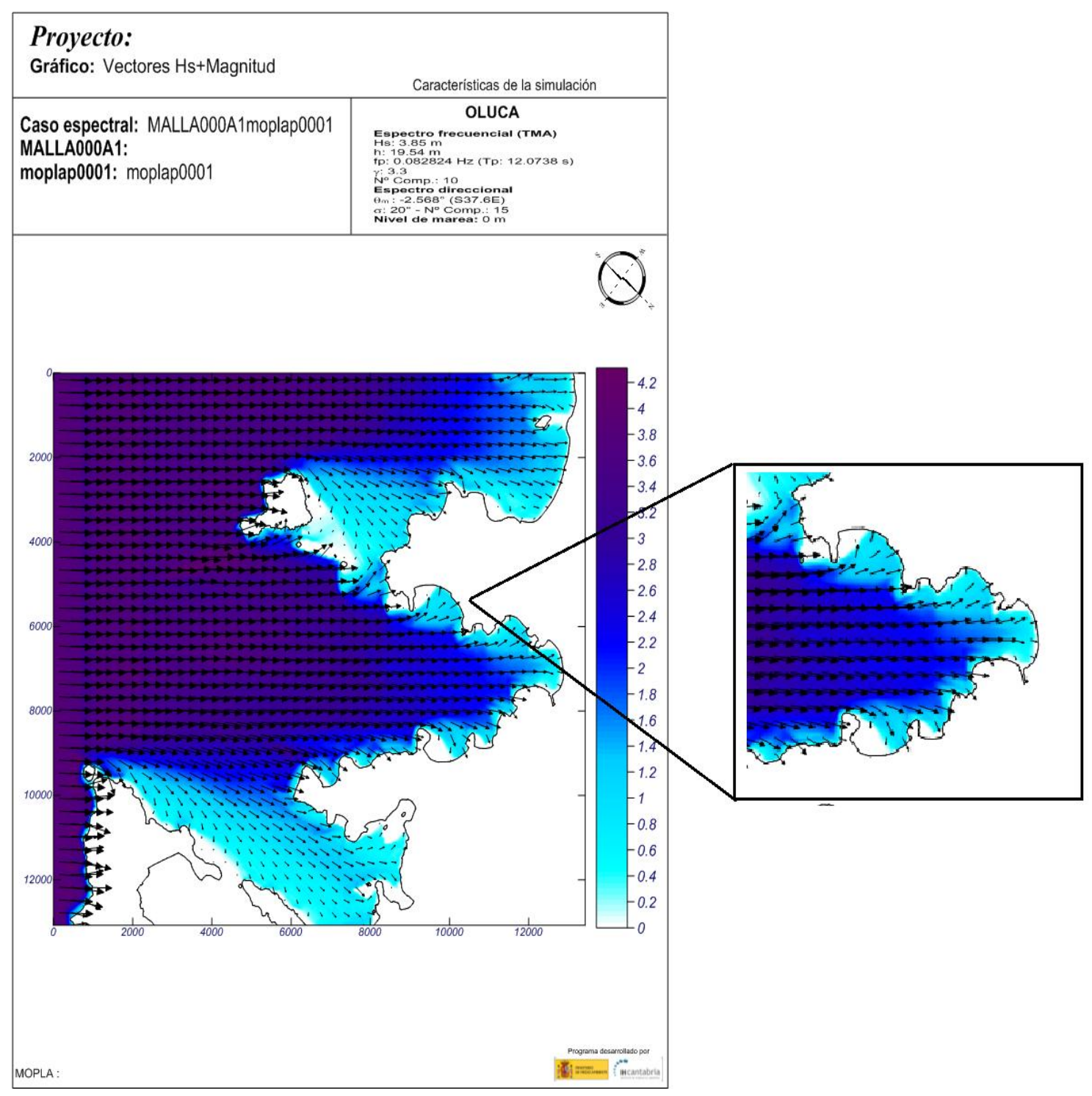

Figura 19 Simulação realizada pelo Sistema de Modelagem Costeira para ondas do quadrante Sul com altura máxima de onda de $3,85 \mathrm{~m}$. 


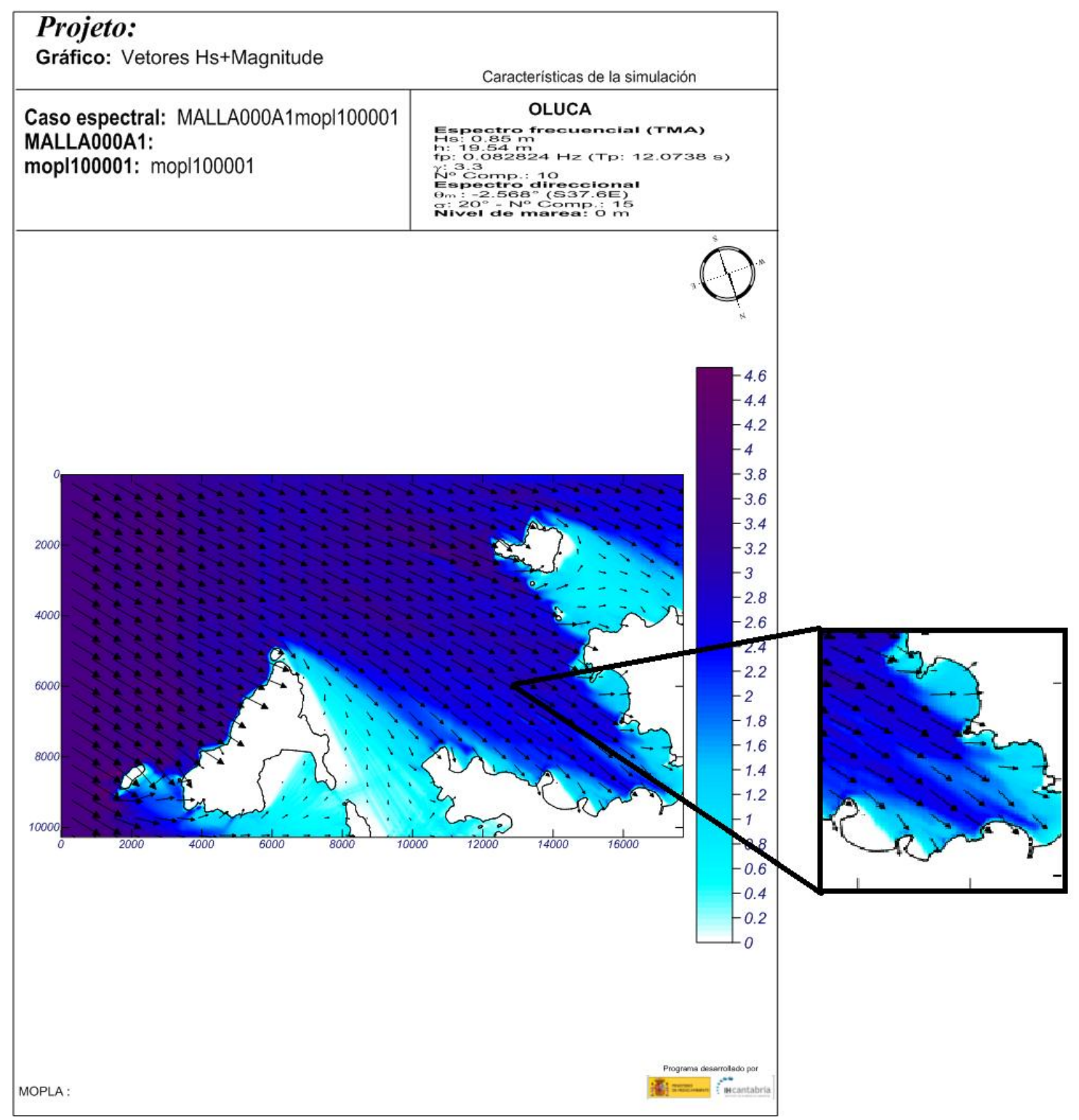

Figura 20 Simulação realizada pelo Sistema de Modelagem Costeira para ondas do quadrante Sul com altura máxima de onda de 1,00 m. 
5.4. Variações topográficas dos períodos amostrados

As variações altimétricas ocorridas ao longo do período monitorado foram analisadas por gráficos topográficos com isolinhas de diferenças diárias e mensais, permitindo avaliar as possíveis perdas e ganhos sedimentares ao longo de todo o período.

\subsubsection{Praia do Lázaro}

Na Praia do Lázaro a variação sedimentar do trecho foi negativa para todos os meses amostrados. Apresentou a maior perda sedimentar $(-0,96)$ entre o dia 29 e 30 de Agosto, e o maior ganho sedimentar (0,8m), entre 10 e 12 de Julho. Durante o mês de agosto, não foi possível processar a maioria dos dados obtidos, por falha de sinal GPS.

As cúspides praiais apresentaram em todos os perfis uma menor estabilidade, resultando em uma grande variação que se alternou em perdas e ganhos sedimentares.

Muito embora a posição da linha d'água nos perfis levantados seja espacialmente menos precisa do que as bermas ou muros, ainda é possível se identificar um padrão geral erosivo, que corresponde a perdas altimétricas mais significativas na linha d'água se comparadas com os limites superiores que apresentam um padrão mais deposicional.

Os levantamentos realizados no período de Junho de 2012 indicaram que do dia 19 para o dia 20 (Fig.21), o trecho analisado da Praia do Lázaro, apresentou uma variação altimétrica entre $0,31 \mathrm{~m}$ e $-0,04 \mathrm{~m}$, apresentando uma variação sedimentar positiva. As cúspides praias foram as feições que mais obtiveram ganho sedimentar $(0,16 \mathrm{~m}$ a $0,21 \mathrm{~m})$. No limite superior do trecho os ganhos foram menores e em alguns pontos ocorreu uma pequena perda sedimentar. Do dia 20 para o dia 21 (Fig.22) a 
variação foi negativa $(0,08 \mathrm{~m}$ a $-0,42 \mathrm{~m})$, apresentando perda sedimentar em todo o trecho, com exceção das cúspides que obtiveram um pequeno ganho sedimentar em alguns pontos isolados. Do dia 21 para o dia 22 (Fig.23) a variação foi positiva (0,03 m a $-0,42 m)$. A maior variação negativa encontrada foi na extremidade da área a oeste do trecho, próximo ao rio $(-0,42 \mathrm{~m})$. Foi observado ganhos sedimentares $(0,2 \mathrm{~m}$ a $0,3 \mathrm{~m})$ na área a leste, tanto na linha d'água como no limite superior. As menores variações foram observadas nas cúspides, apresentando perdas sucessivas de $-0,17 \mathrm{~m}$ a $-0,22 \mathrm{~m}$ com as maiores perdas da área oeste do que a área leste. Do dia 22 para o dia 23 (Fig. 24) o trecho apresentou variação negativa $(0,10$ a $-0,40)$. As maiores perdas sedimentares ocorreram da área a leste pra a área a oeste, com um pequeno acréscimo no extremo da área oeste, próximo ao rio. As cúspides variaram sucessivamente entre -0,25m e -0,04m.

O período total amostrado na Praia do Lázaro durante o mês de Junho (Fig.25), apresentou como resultado final, uma variação negativa, com perda sedimentar em todo o trecho $(-0,01$ a -0,56). As maiores perdas ocorreram no extremo da área a oeste, sendo a variação de $-0,36 \mathrm{~m}$ predominante no trecho. A variação volumétrica foi de $-874,56 \mathrm{~m}^{3}$. 


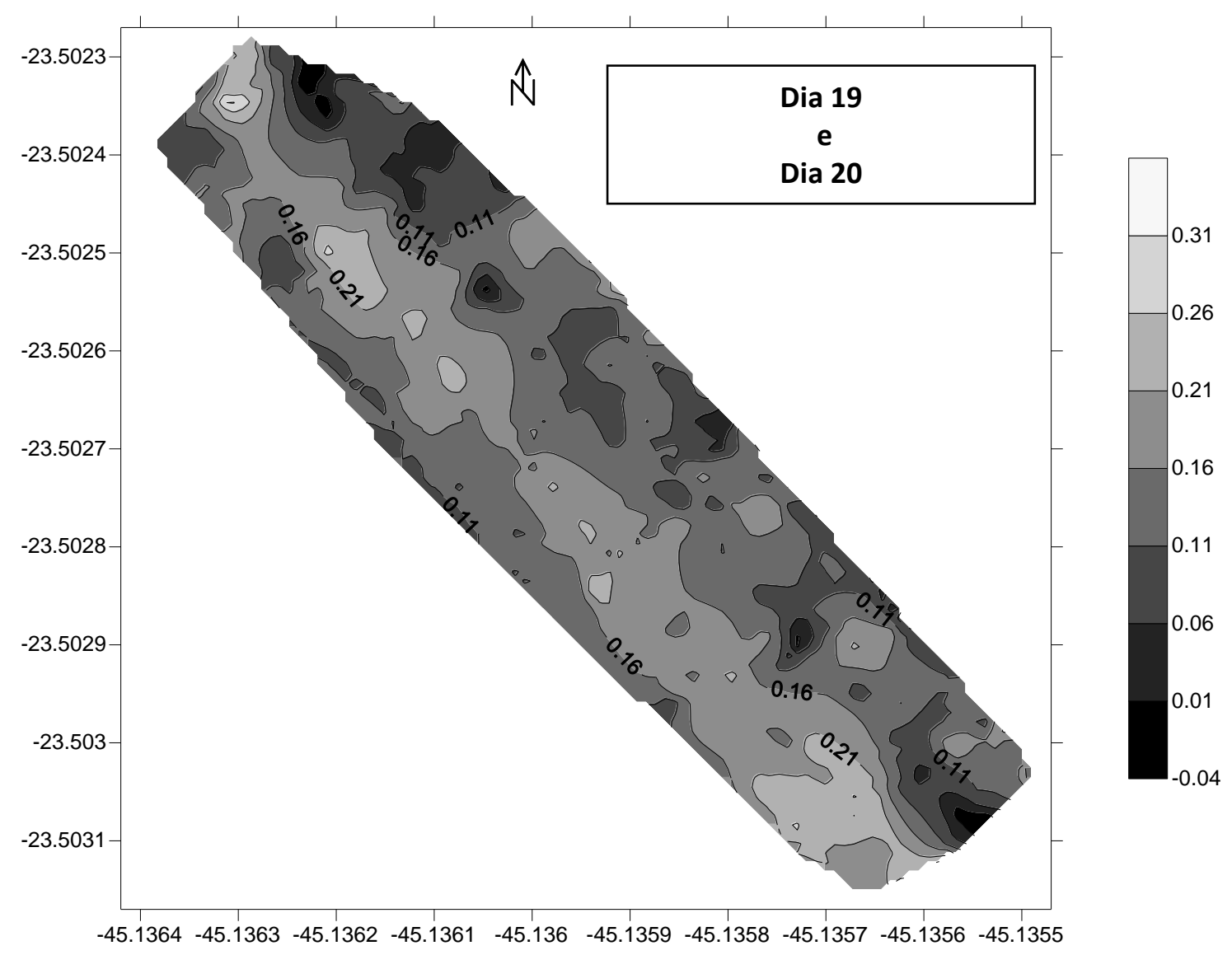

Figura 21 Gráfico de variação topográfica entre os dias 19 e 20 de junho de 2012 para a praia do Lázaro. 


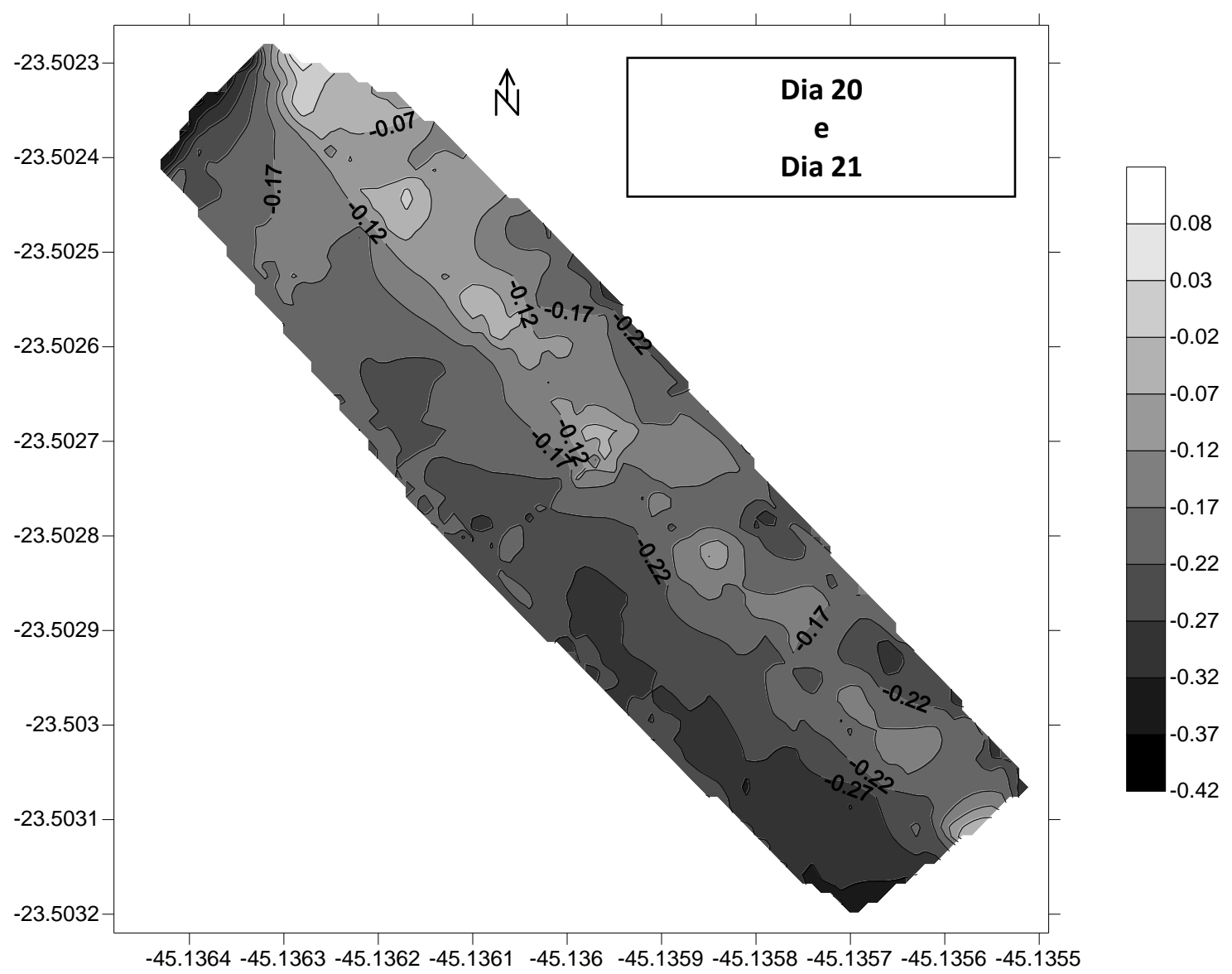

Figura 22 Gráfico de variação topográfica entre os dias 20 e 21 de junho de 2012 para a praia do Lázaro. 


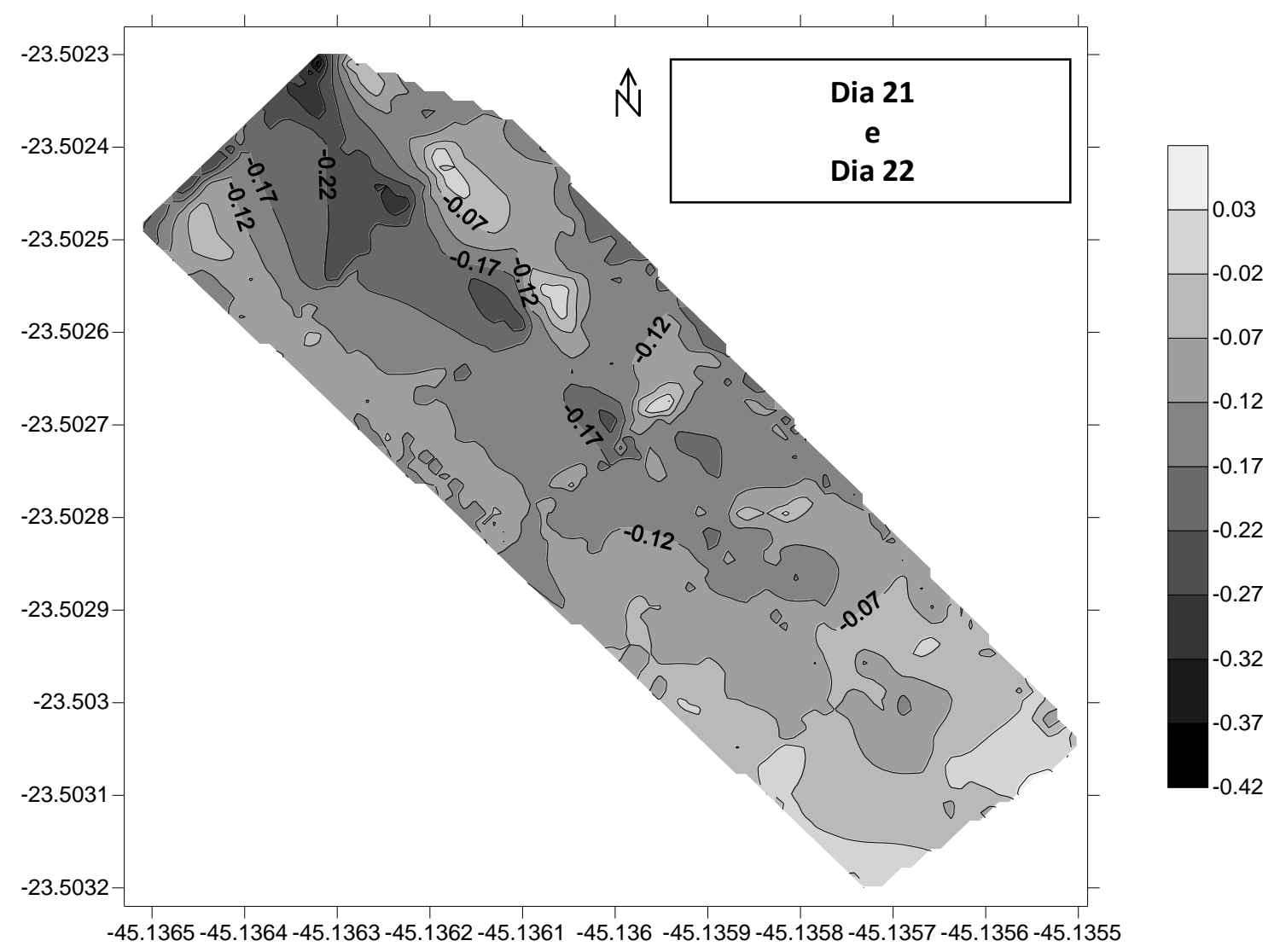

Figura 23 Gráfico de variação topográfica entre os dias 21 e 22 de junho de 2012 para a praia do Lázaro. 


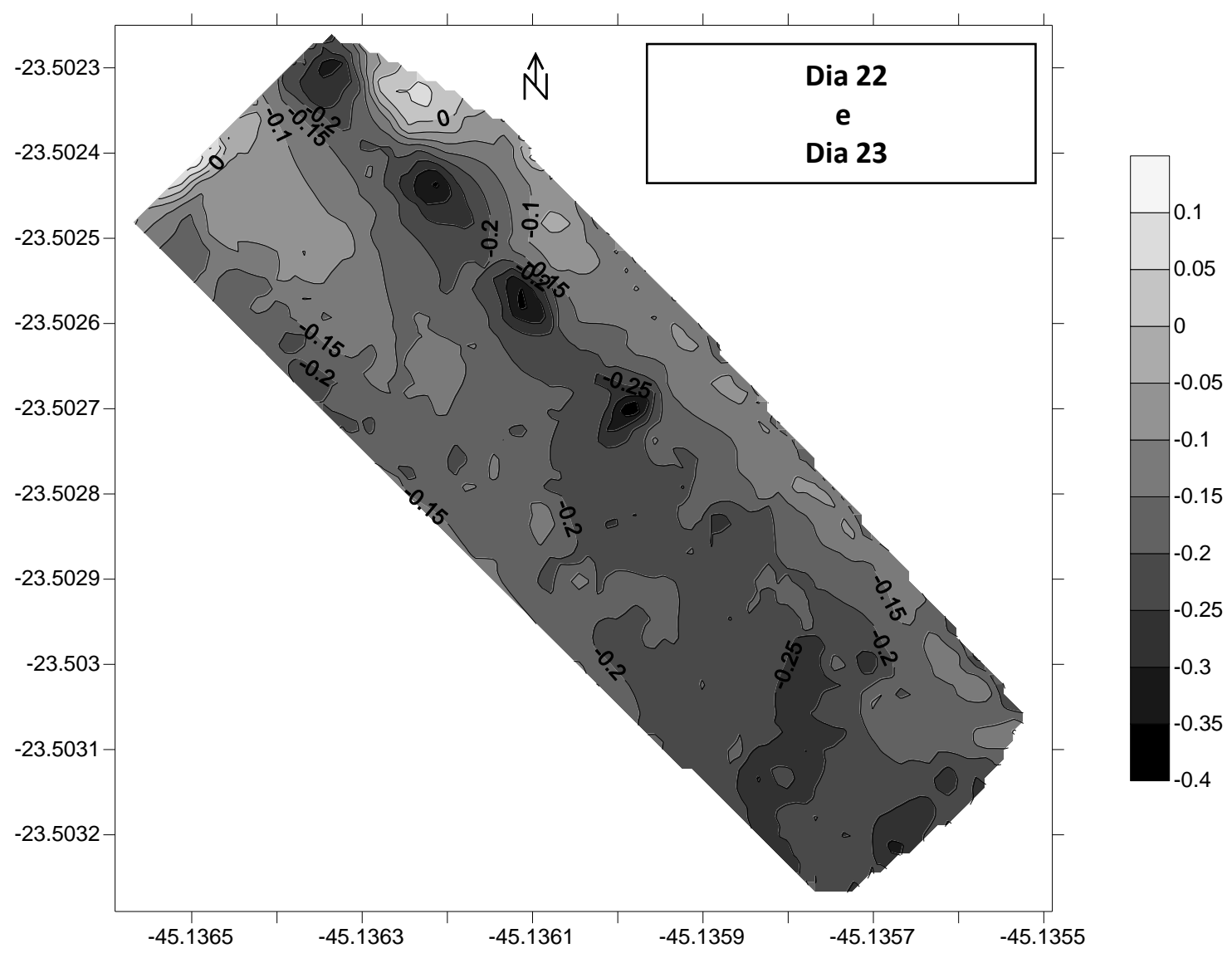

Figura 24 Gráfico de variação topográfica entre os dias 22 e 23 de junho de 2012 para a praia do Lázaro. 


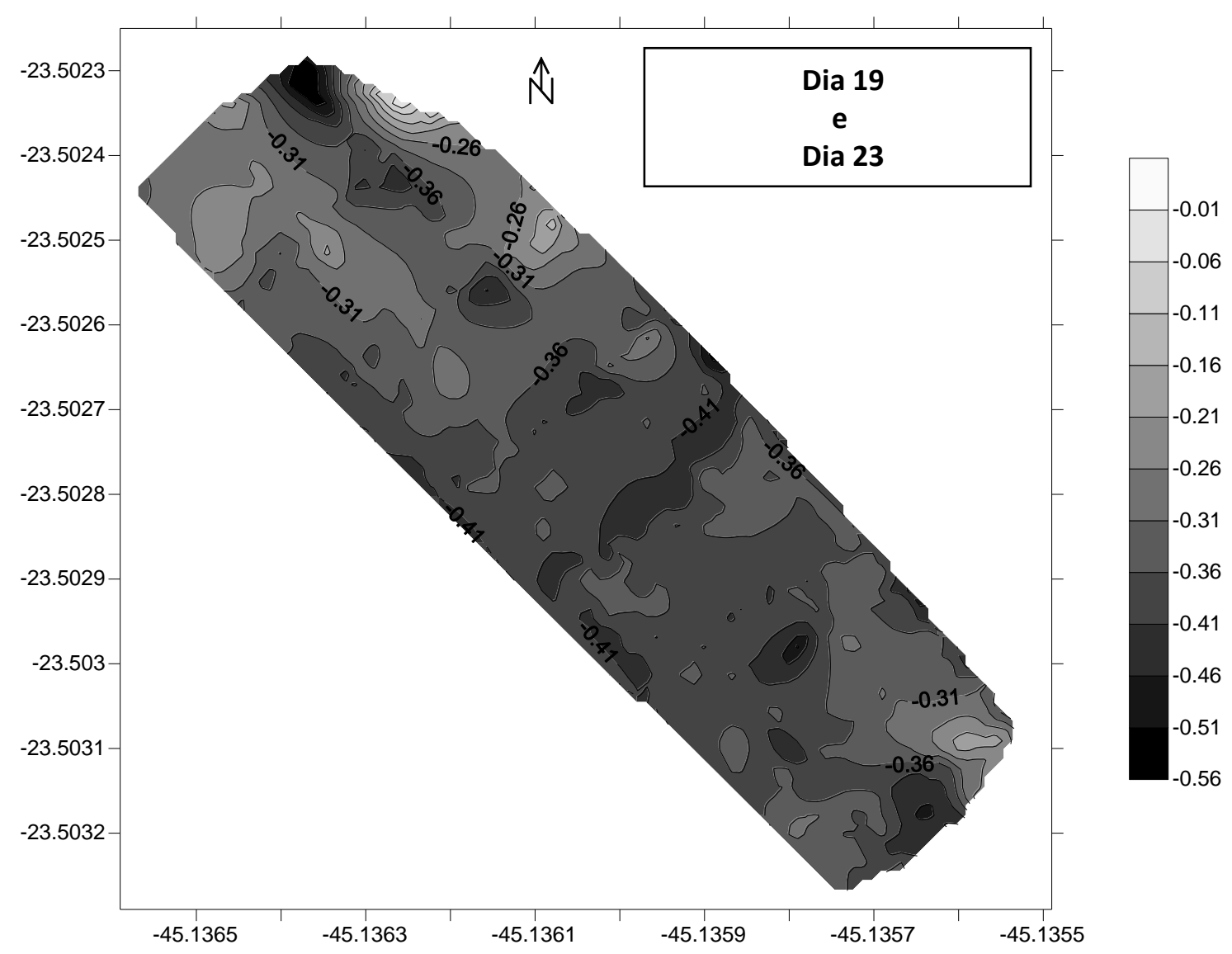

Figura 25 Gráfico de variação topográfica entre os dias 19 e 23 de junho de 2012 para a praia do Lázaro.

Os levantamentos realizados no período de Julho de 2012 indicaram que do dia 09 para o dia 10 (Fig.26) o trecho apresentou uma variação negativa (0,2m a -0,7m). A tendência erosiva ocorreu crescentemente da área a oeste para a área a leste $(-0,4 \mathrm{~m}$ a 0,7m). Entre o dia 10 e dia 12 (Fig.27), as variações altimétricas ocorreram entre 0,8 e 0,1, apresentando ganho sedimentar crescente da área a oeste para a área a leste. Do dia 12 para 13 (Fig.28) a variação encontrada foi de $0,31 \mathrm{~m}$ a $0,06 \mathrm{~m}$, representando ganho sedimentar $(0,16 \mathrm{~m})$ em praticamente toda sua extensão, com exceção da área a leste, onde a variação foi menor $(0,06 \mathrm{~m}$ a $0,16 \mathrm{~m})$.

A praia do Lázaro apresentou para o mês de Julho (Fig.29) uma variação entre $0,23 \mathrm{~m}$ e $0,68 \mathrm{~m}$, resultando em ganho sedimentar. $\mathrm{O}$ centro do trecho levantado foi o 
local onde os ganhos foram maiores $(0,53 \mathrm{~m}$ a $0,68 \mathrm{~m})$, seguido pela área a oeste $(0,43 \mathrm{~m}$ a $0,63 \mathrm{~m})$ e finalmente a área a leste $(0,23 \mathrm{~m}$ a $0,43 \mathrm{~m})$. Foi observada para esse mês uma maior variação das cotas de maré. Como esse comportamento é atípico na área de estudo, não foi possível amostrar a linha d’água, já que os levantamentos foram realizados em diferentes cotas de maré. A variação volumétrica foi de $491,51 \mathrm{~m}^{3}$.

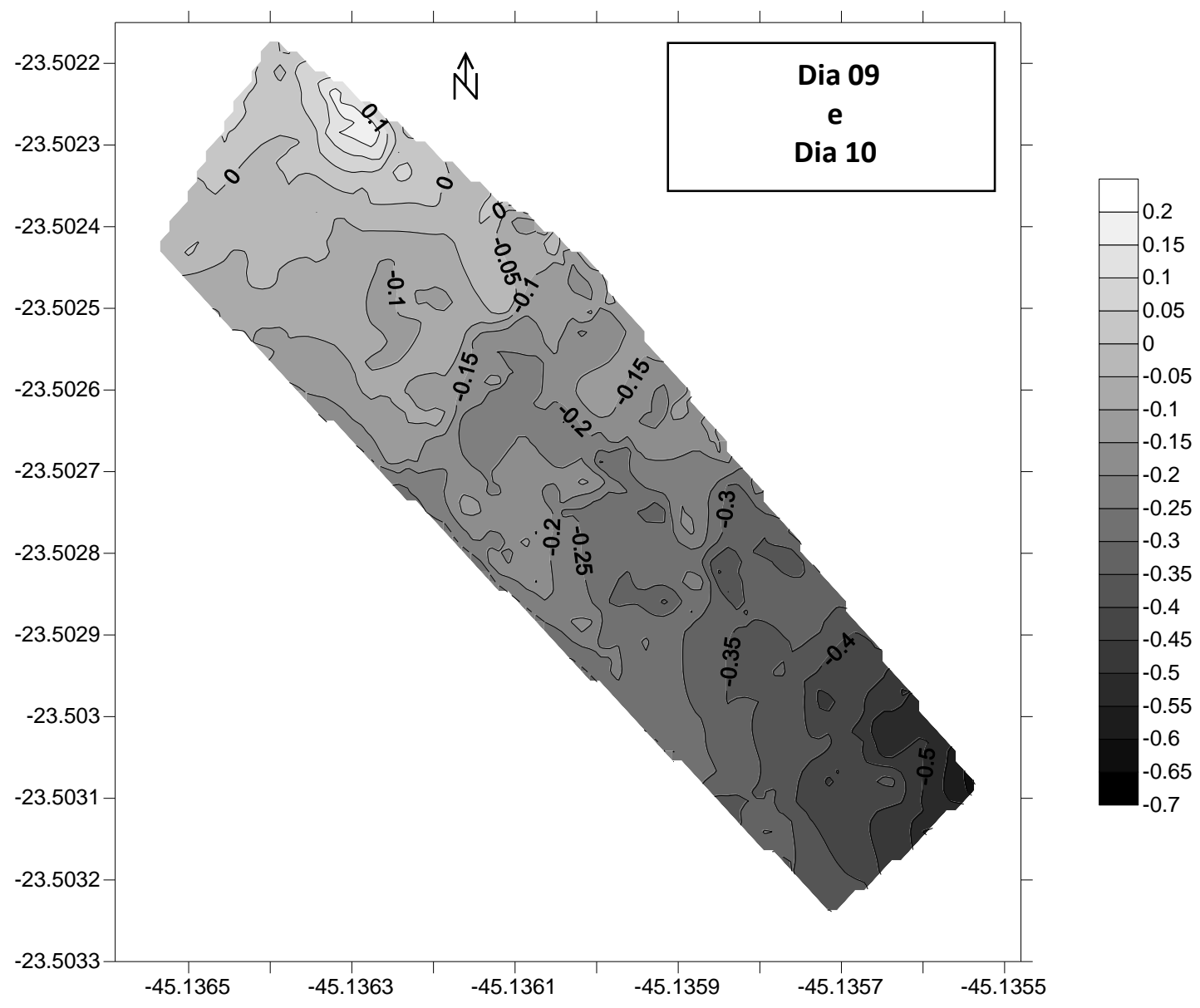

Figura 26 Gráfico de variação topográfica entre os dias 09 e 10 de julho de 2012 para a praia do Lázaro. 


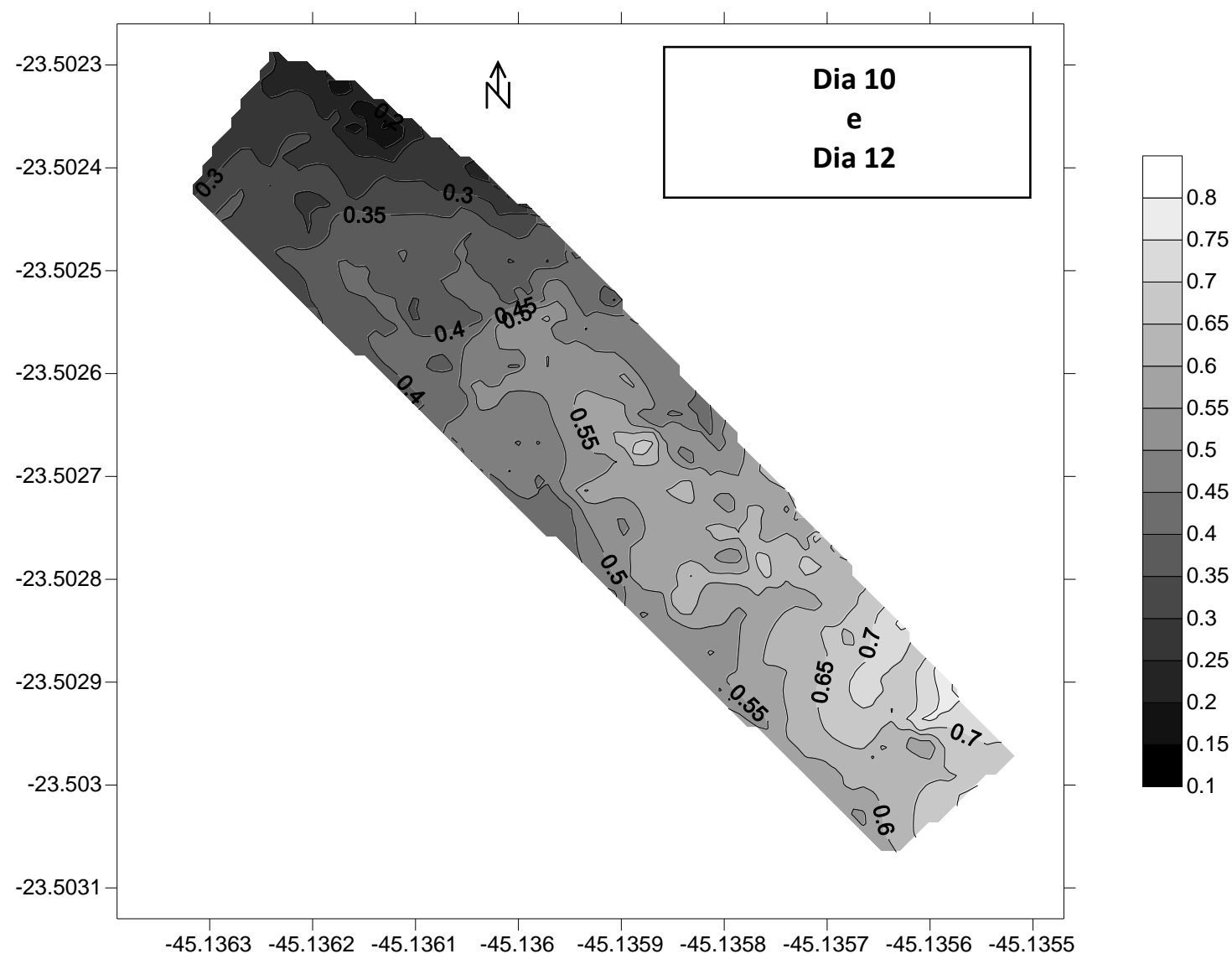

Figura 27 Gráfico de variação topográfica entre os dias 10 e 12 de julho de 2012 para a praia do Lázaro. 


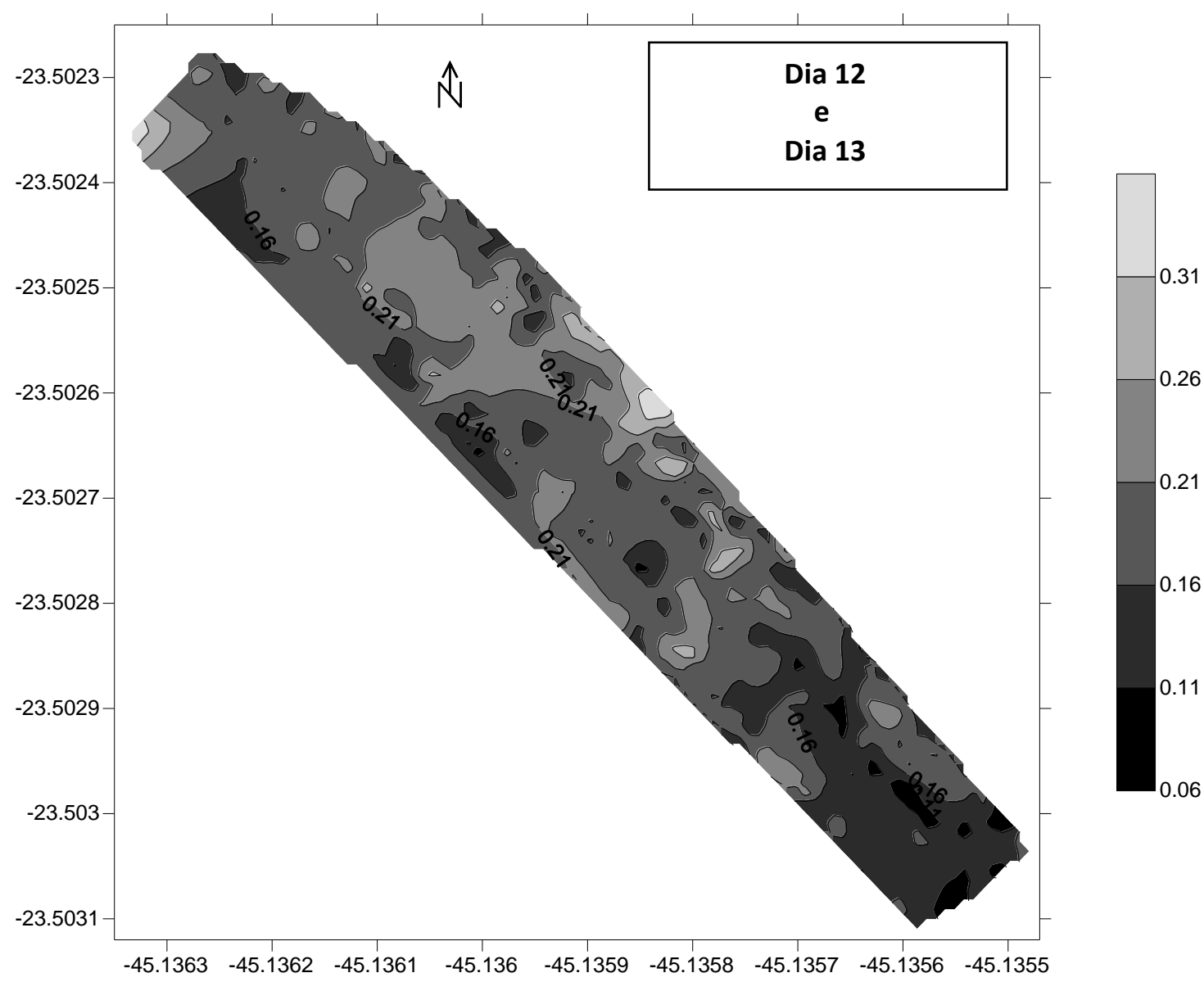

Figura 28 Gráfico de variação topográfica entre os dias 12 e 13 de julho de 2012 para a praia do Lázaro. 


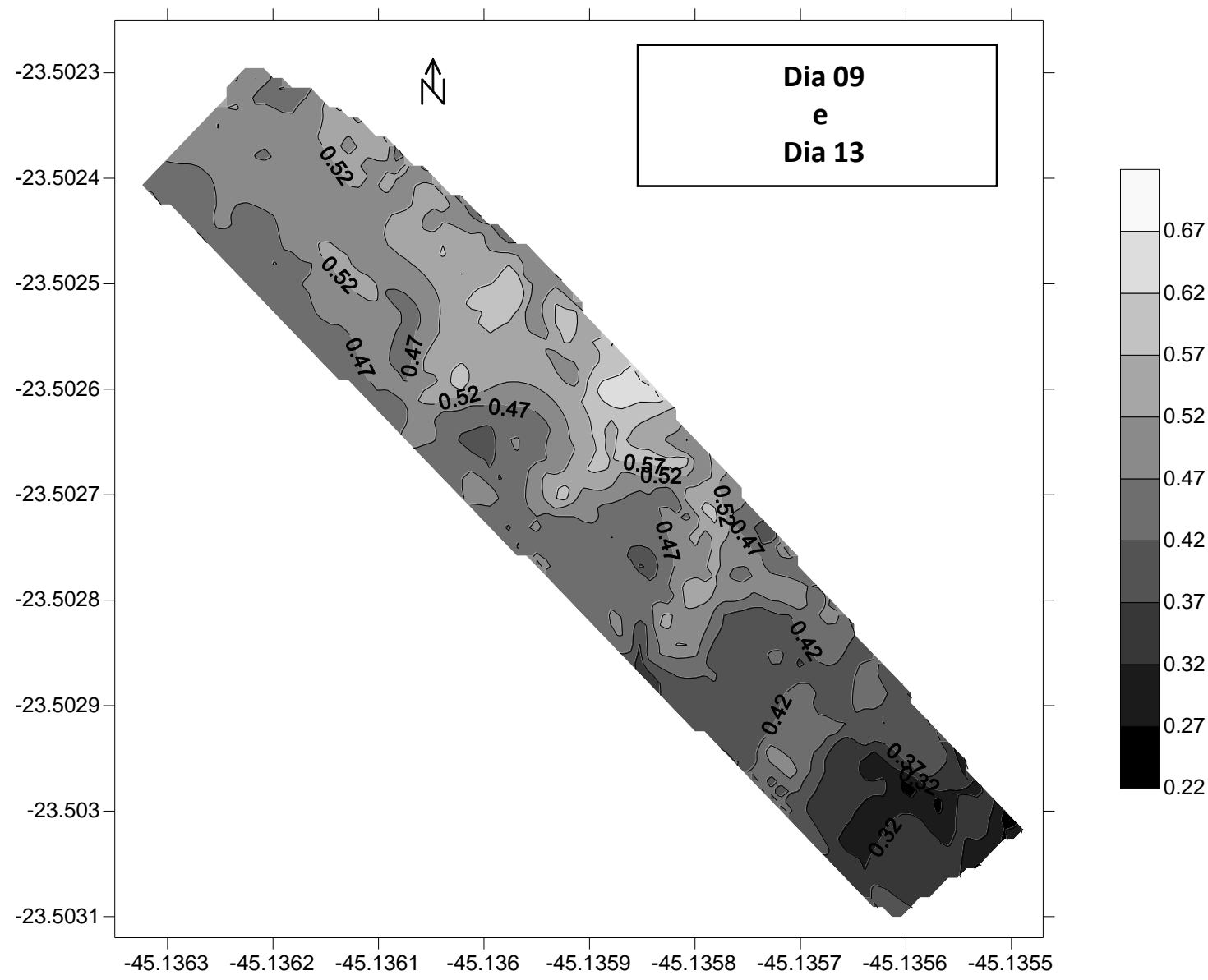

Figura 29 Gráfico de variação topográfica entre os dias 09 e 13 de julho de 2012 para a praia do Lázaro.

Para a praia do Lázaro durante o mês de Agosto, por conta de instabilidade do sinal dos satélites na área de estudo, foi possível obter resultados apenas para dia 29 e 30.

Do dia 29 para 30 (Fig.30), o trecho da Praia do Lázaro amostrado, apresentou uma variação negativa entre $-0,46 \mathrm{~m}$ e $-0,96 \mathrm{~m}$ resultando em perda sedimentar crescente da linha d'água para o limite superior. A variação volumétrica foi de $-69,77 \mathrm{~m}^{3}$. 


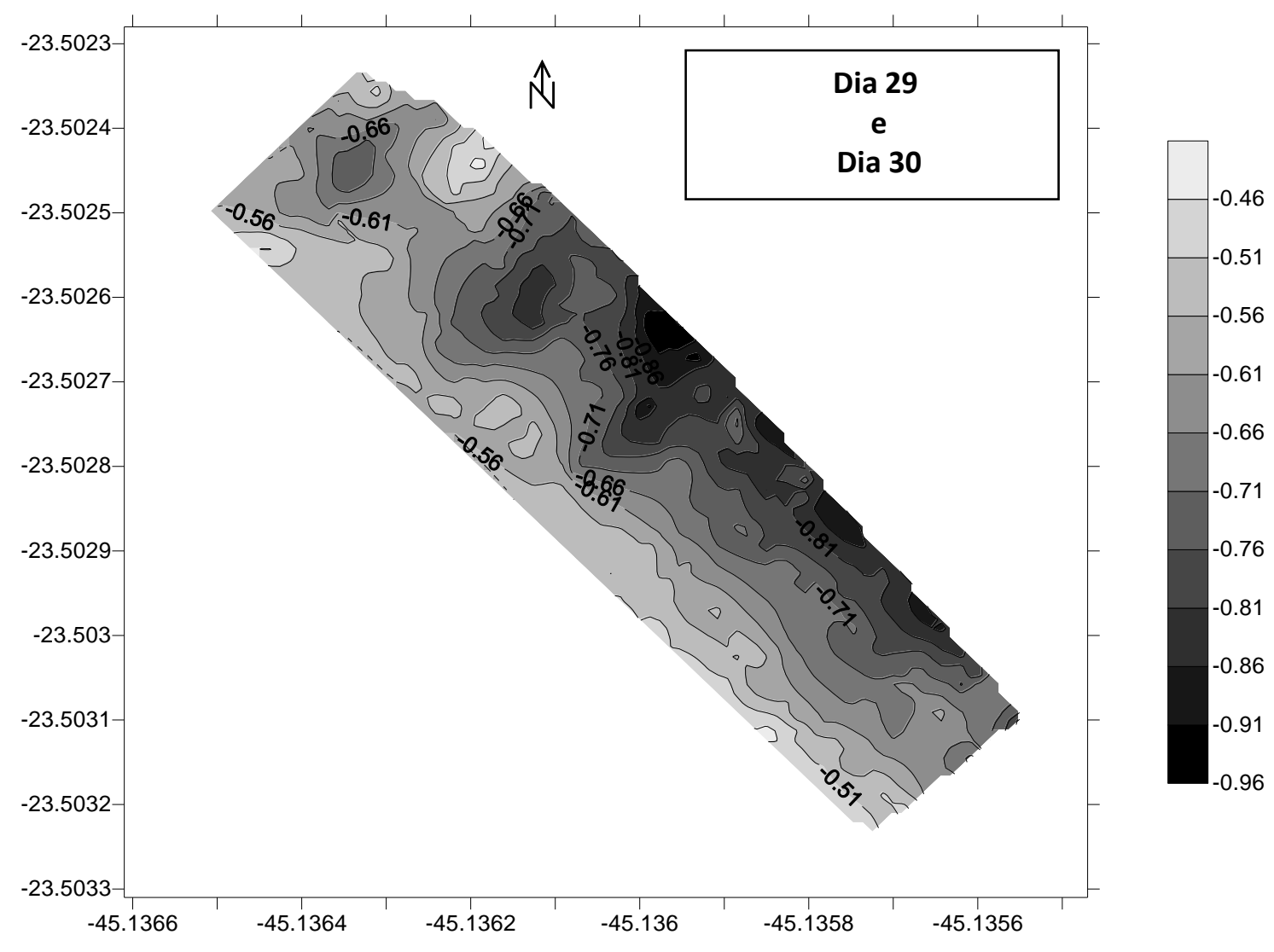

Figura 30 Gráfico de variação topográfica entre os dias 29 e 30 de Agosto de 2012 para a praia do Lázaro.

Entre as campanhas do Mês de Junho e Julho (Fig.31), a variação sedimentar do trecho foi positiva $(0,56 \mathrm{~m}$ a $0,06 \mathrm{~m})$. A área a oeste obteve a menor variação observada $(0,06 \mathrm{~m}$ a $0,31 \mathrm{~m})$, seguido pelo centro do trecho. A área a leste variou entre $0,31 \mathrm{~m}$ e $0,46 \mathrm{~m}$ e o limite superior obteve o maior ganho sedimentar $(0,56 \mathrm{~m}$ a $0,36 \mathrm{~m})$.

O perfil do mês de Julho para Agosto (Fig.32) apresentou uma variação negativa $(-0,09 \mathrm{~m}$ a $-0,44 \mathrm{~m})$. entre a área a oeste e a central ocorreu uma alternância entre perdas maiores $(-0,29 \mathrm{~m}$ a $-0,44 \mathrm{~m})$ e menores $(-0,14 \mathrm{~m}$ a $-0,29 \mathrm{~m})$. Na área leste ocorreu uma maior estabilidade com pequena perda sedimentar $(-0,09 \mathrm{~m}$ a $-0,19 \mathrm{~m})$.

Entre o primeiro dia do mês de Junho e o último dia do mês de Agosto (Fig.33), o levantamento apresentou uma variação total negativa $(-0,22 \mathrm{~m}$ a $0,72 \mathrm{~m})$. As 
perdas sedimentares ocorreram do centro do trecho $(-0,5 \mathrm{~m}$ a $-0,72 \mathrm{~m})$ para as extremidades $\quad(-0,2 \mathrm{~m}$ a $-0,5 \mathrm{~m})$. A variação volumétrica foi de $-68,65 \mathrm{~m}^{3}$.

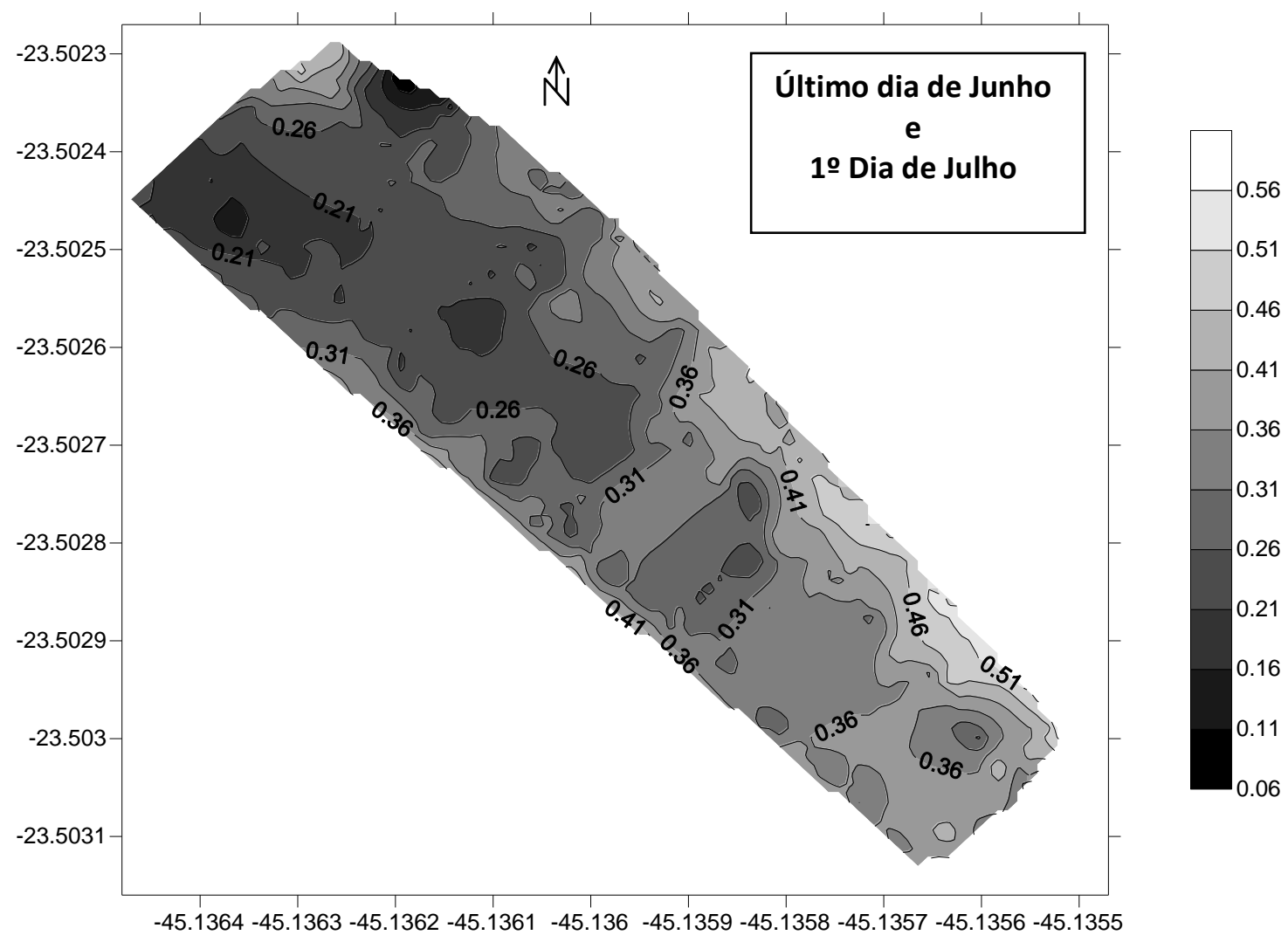

Figura 31 Gráfico de variação topográfica entre o último dia de junho e o primeiro dia de Julho de 2012 para a praia do Lázaro. 


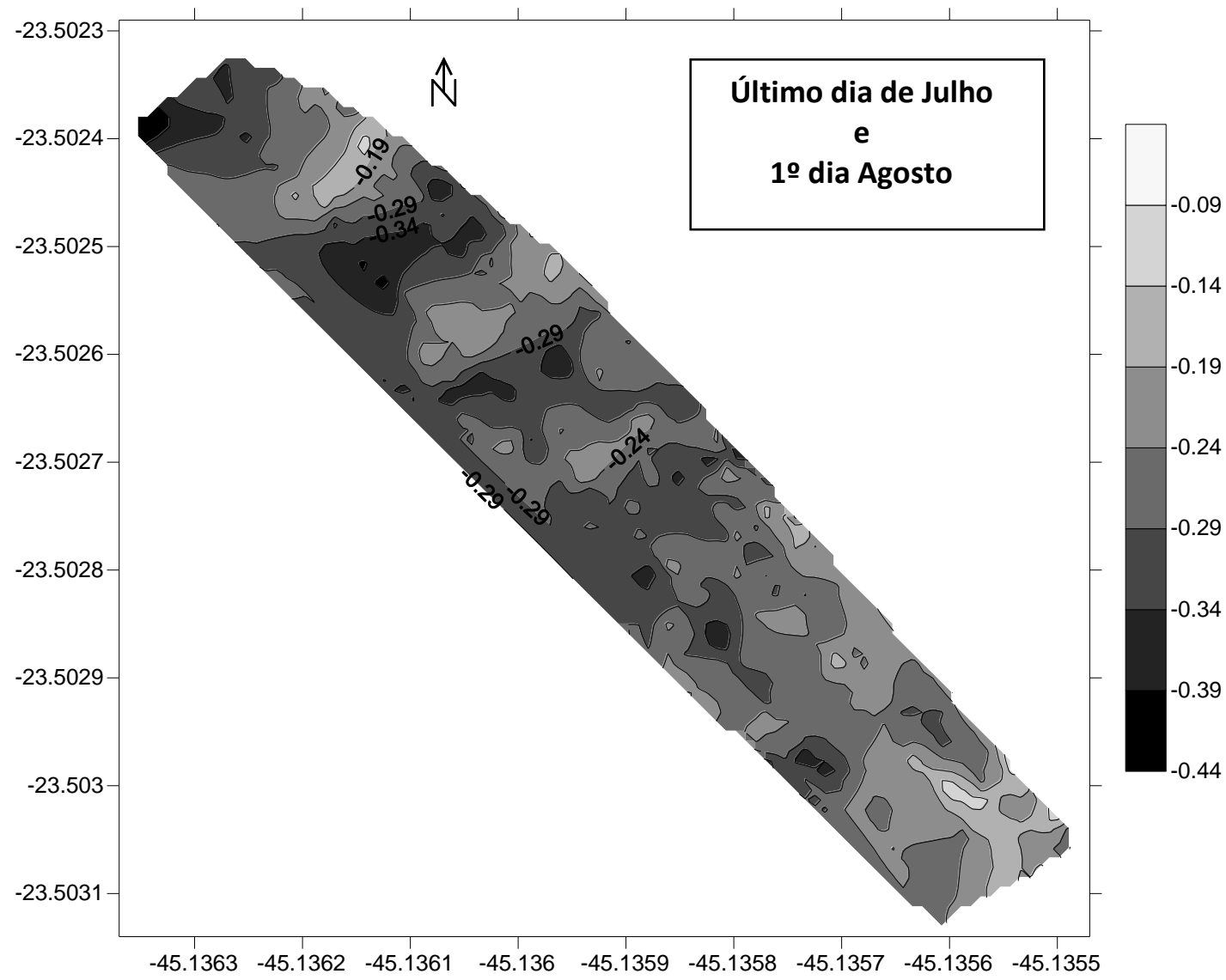

Figura 32 Gráfico de variação topográfica da Praia do Lázaro entre o último dia de julho e o primeiro dia de Agosto de 2012 para a praia do Lázaro. 


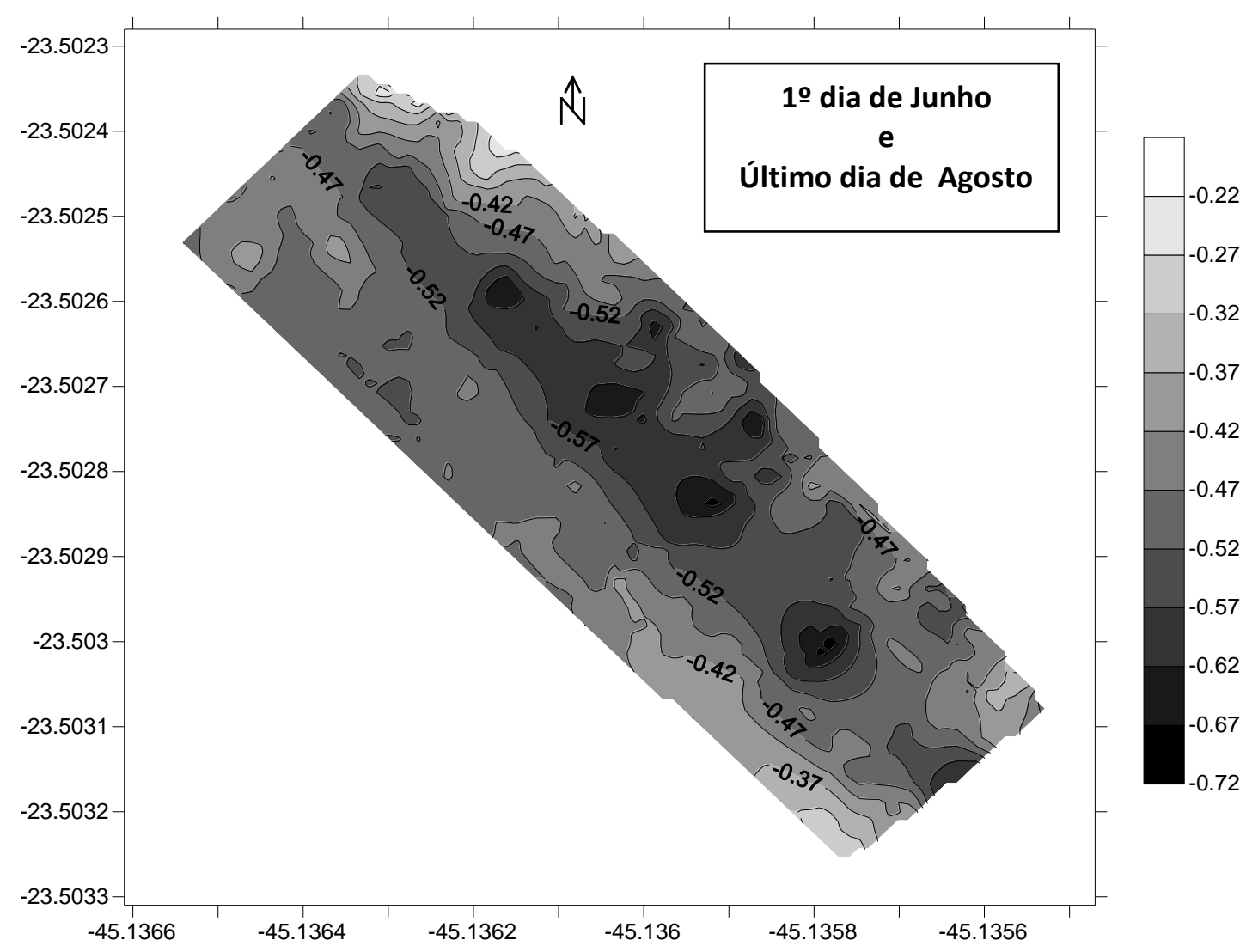

Figura 33 Gráfico de variação topográfica entre o primeiro dia de junho e o último dia de Julho de 2012 para a praia do Lázaro.

\subsubsection{Praia da Domingas Dias}

A praia da Domingas Dias, ao longo de todo o período de levantamento, apresentou perda sedimentar. A maior perda $(-0,95 \mathrm{~m})$ foi identificada no setor mais leste da área, entre o dia 8 e 9 e o maior ganho ( $1,2 \mathrm{~m})$ entre o dia 10 e 12 , no mesmo setor, ambas durante o mês de Julho.

A posição da linha d'água se apresentou espacialmente de maneira estável na maioria das campanhas, com uma maior variabilidade na área a oeste e menor a leste da praia. 
Em todas as campanhas foram observadas o presença de cúspides praiais com significativas variações de posição sobre o prisma praial.

Os levantamentos executados no período de Junho de 2012 indicaram que do dia 18 para o dia 19 (Fig.34), observou-se uma perda sedimentar, com alterações que corresponderam a uma variação topográfica entre $-0,08$ e $-0,58$. Para esse período as variações altimétricas foram crescentes de leste para oeste, e a linha d'água se mostrou espacialmente estável. Do dia 19 para 21 (Fig.35) a variação continuou negativa, apresentando perda sedimentar que variou de $-0,19 \mathrm{~m}$ a $-0,74 \mathrm{~m}$. A parte central do trecho apresentou as menores variações $(-0,19 \mathrm{~m}$ a $-0,44 \mathrm{~m})$, enquanto as maiores variações foram encontradas na parte superior (berma) e inferior (linha d'água). O valor predominante encontrado foi de $-0,59$ m. A variação do dia 21 para 22 (Fig.36) de Junho variaram entre $-0,55$ e $0,2 \mathrm{~mm}$, com uma tendência negativa na variação sedimentar. As maiores variações de acréscimo ocorreram no setor leste, enquanto o centro e a área a oeste apresentaram perda sedimentar, sendo a variação negativa predominante de $-0,05$.

Os gráficos apresentam uma variação total negativa para mês de Junho (Fig.37), com variação entre $-0,2 \mathrm{~m}$ e $-1,4 \mathrm{~m}$, decrescente na área a oeste para a área leste. A variação volumétrica total foi em $-584,28 \mathrm{~m}^{3}$. 


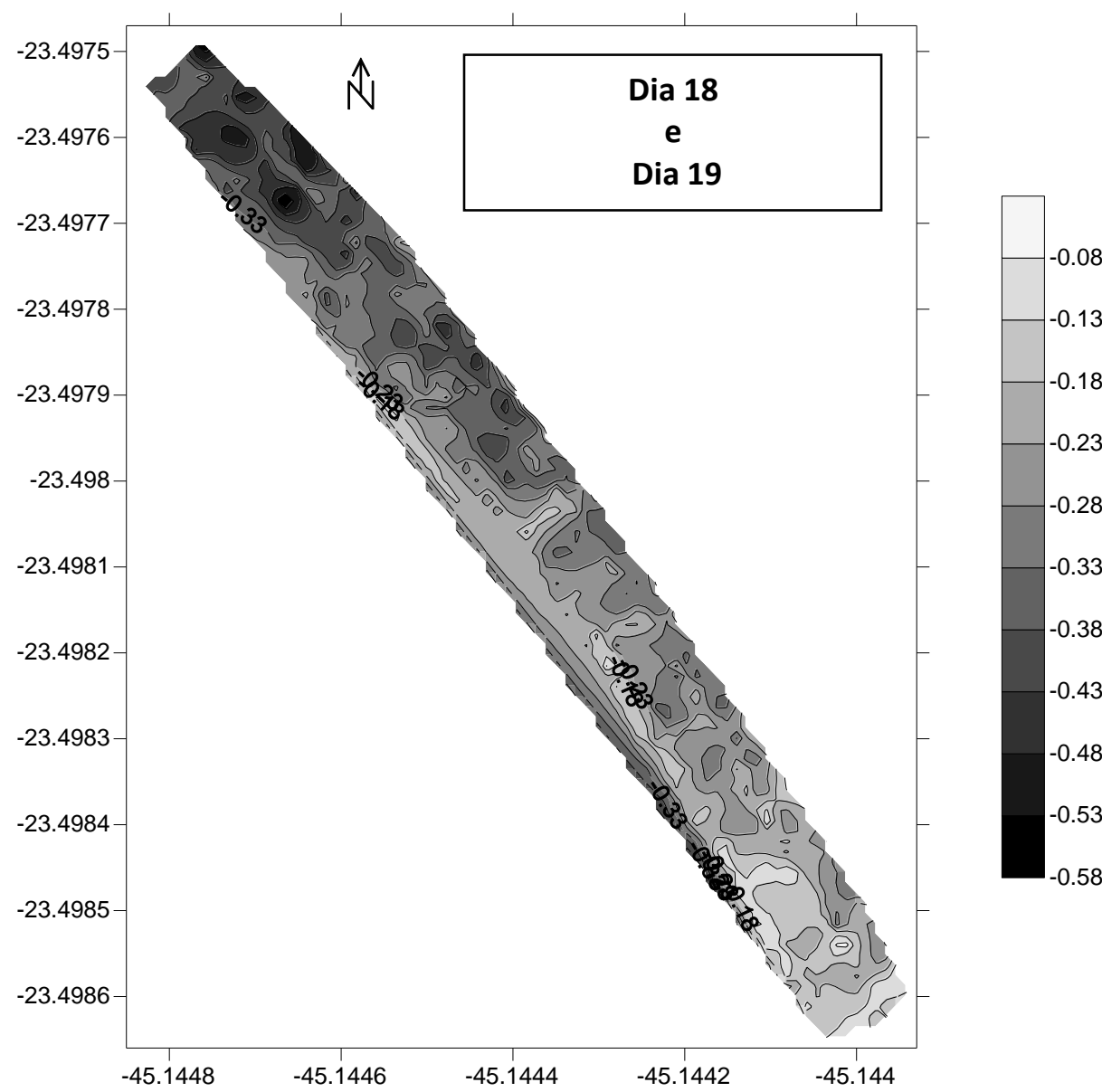

Figura 34 Gráfico de variação topográfica da Praia Domingas Dias entre os dias 18 e 19 de Junho de 2012. 


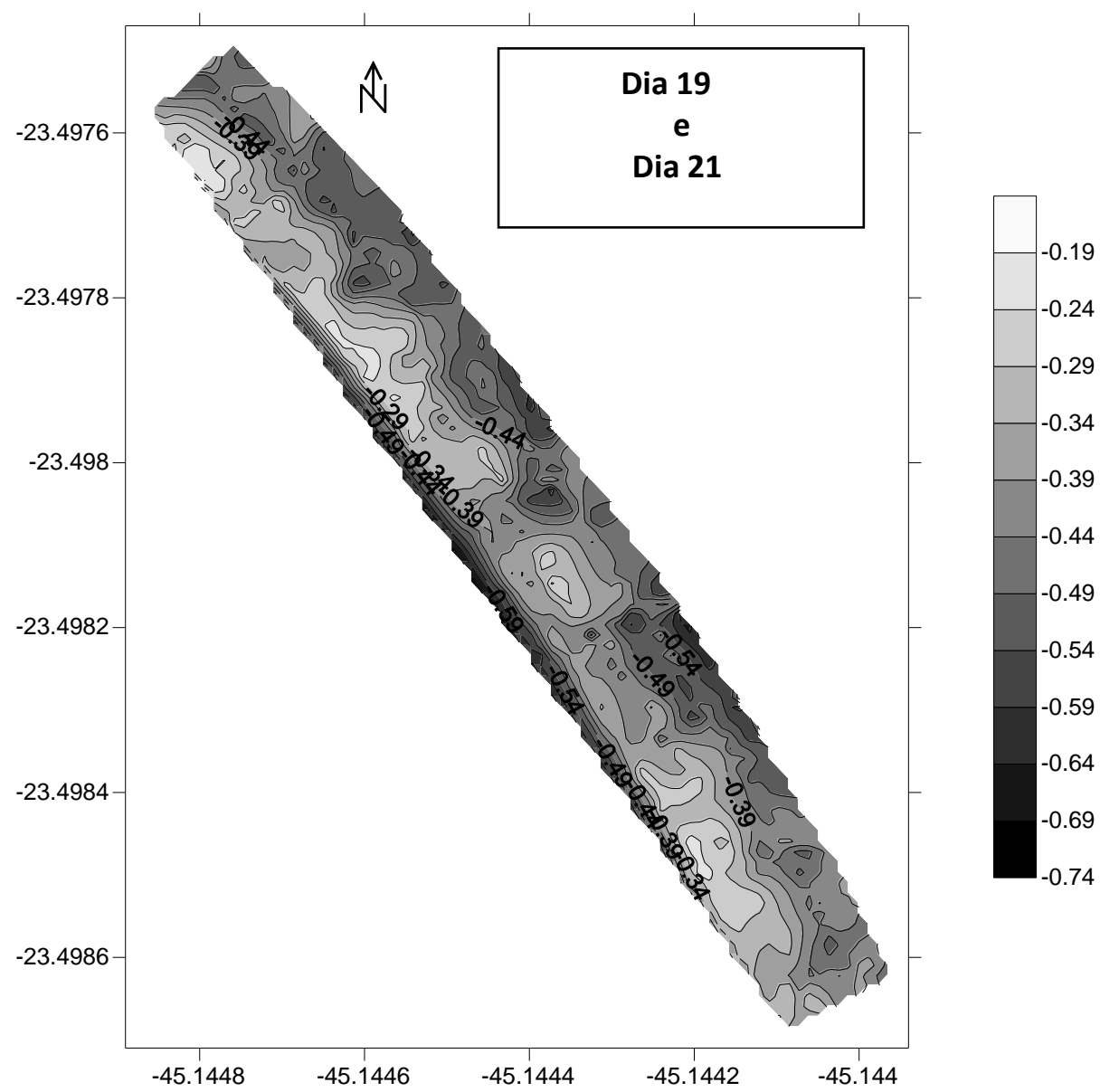

Figura 35 Gráfico de variação topográfica da Praia Domingas Dias entre os dias 19 e 21 de Junho de 2012. 


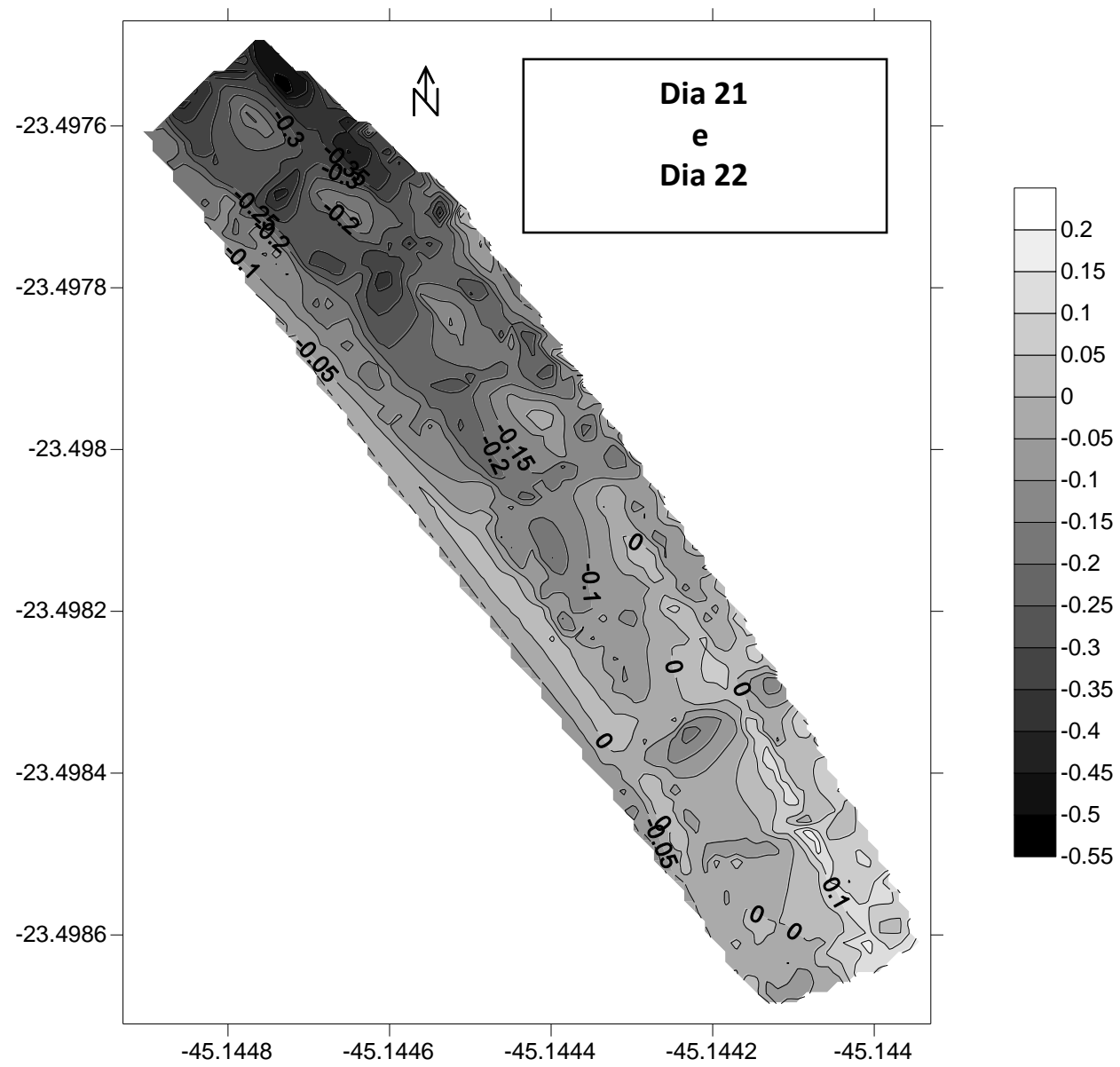

Figura 36 Gráfico de variação topográfica da praia Domingas Dias entre os dias 21 e 22 de Junho de 2012. 


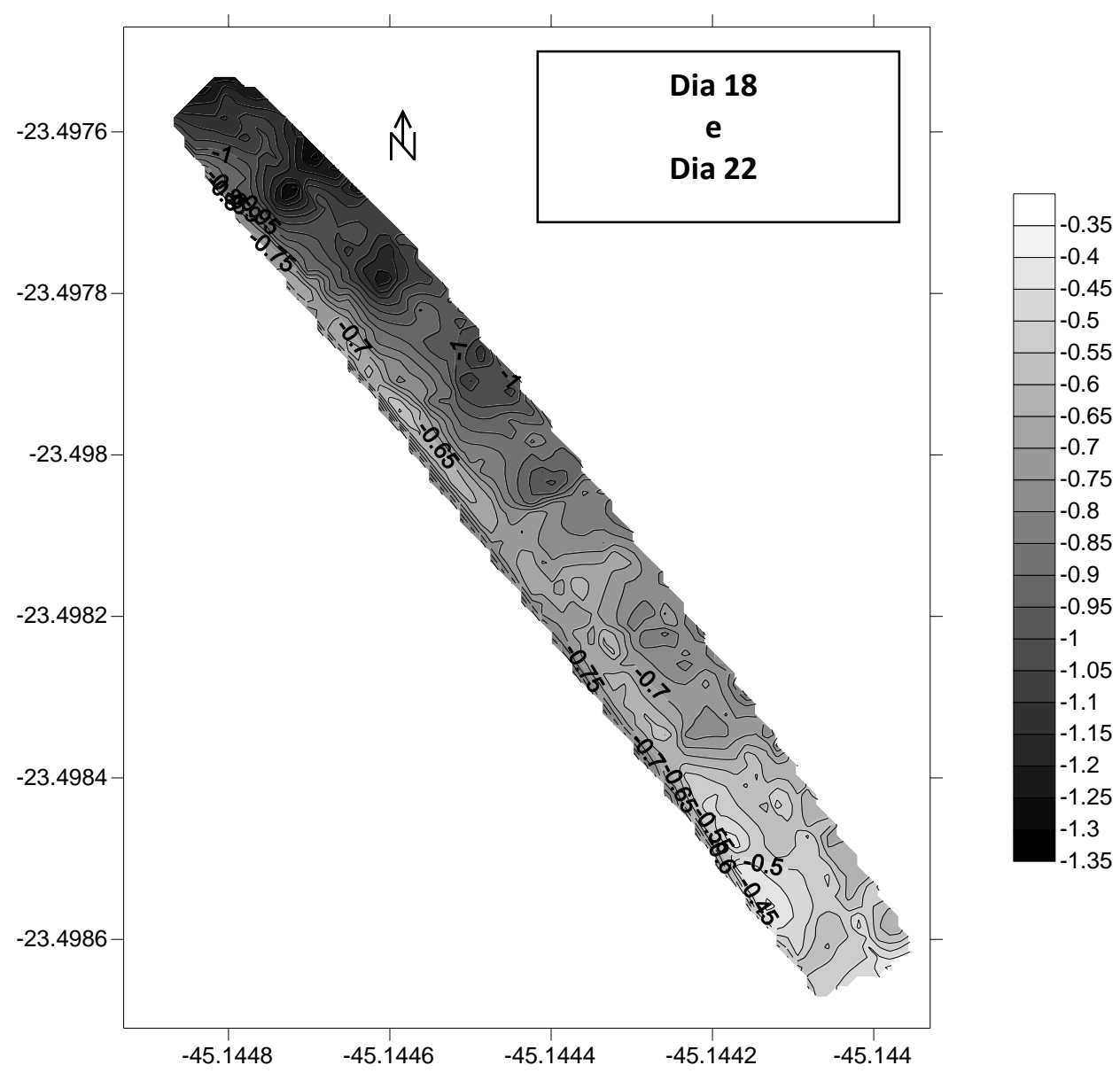

Figura 37 Gráfico de variação topográfica da Praia Domingas Dias entre os dias 18 e 22 de Junho de 2012.

Os levantamentos realizados no período de Julho de 2012 indicaram que do dia 08 para 09 de Julho (Fig.38), foi observado uma variação negativa entre $-0,05 \mathrm{~m}$ e 0,95m, confirmando uma perda sedimentar. O trecho comportou-se de modo decrescente do setor oeste para a área a leste, com uma estabilidade maior nas cúspides praiais e uma maior variação espacial na linha d'água. Do dia 09 para 10 (Fig.39), a variação também foi negativa $(-0,05 \mathrm{~m}$ a $-0,75 \mathrm{~m})$. As maiores perdas ocorreram no limite superior do trecho $(-0,4 \mathrm{~m}$ a $-0,75 \mathrm{~m})$ e as menores $(-0,05 \mathrm{~m}$ a $-0,4 \mathrm{~m})$ junto à linha d'água. As cúspides praiais se mostraram mais pronunciadas nesse período. Do dia 10 para 12 (Fig.40) a variação altimétrica foi entre $1,2 \mathrm{~m}$ e $0,5 \mathrm{~m}$, representando uma variação positiva. As maiores deposições de sedimento $(1,2 \mathrm{~m}$ a $0,9 \mathrm{~m})$ ocorreram no 
limite superior da praia, próximo aos muros das casas e as menores $(0,7 \mathrm{~m}$ a $0,5 \mathrm{~m})$ junto à linha d'água.

Ao longo de todo o período total amostrado (Fig.41) a variação sedimentar do trecho foi negativa $(0,4$ a -0,4). Ocorreu perda sedimentar na linha d'água e na área mais a oeste do perfil e deposição na área leste. O centro e o limite superior se apresentaram mais estáveis. A variação volumétrica total foi de $31,90 \mathrm{~m}^{3}$.

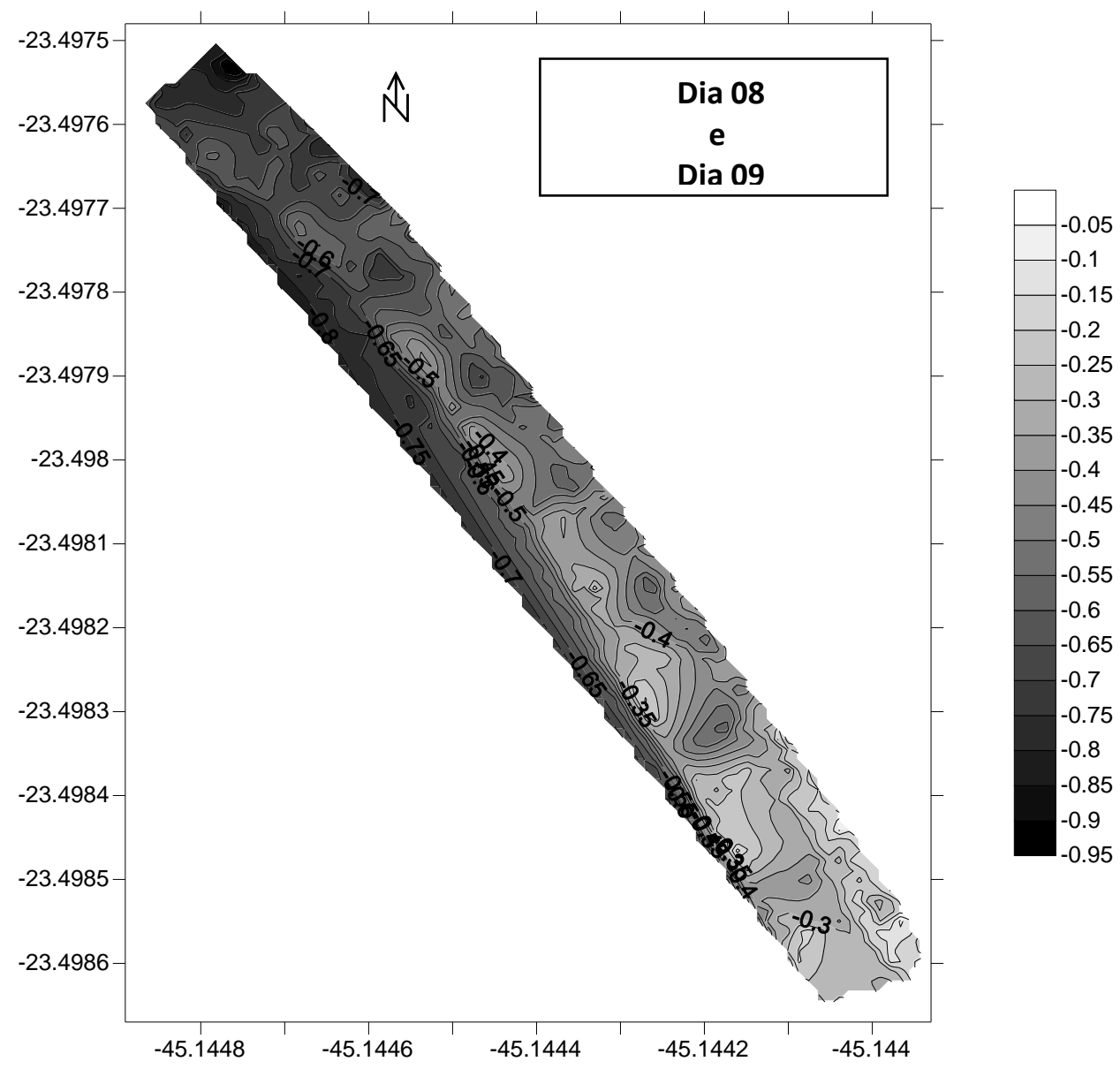

Figura 38 Gráfico de variação topográfica da praia Domingas Dias entre os dias 08 e 09 de Julho de 2012. 


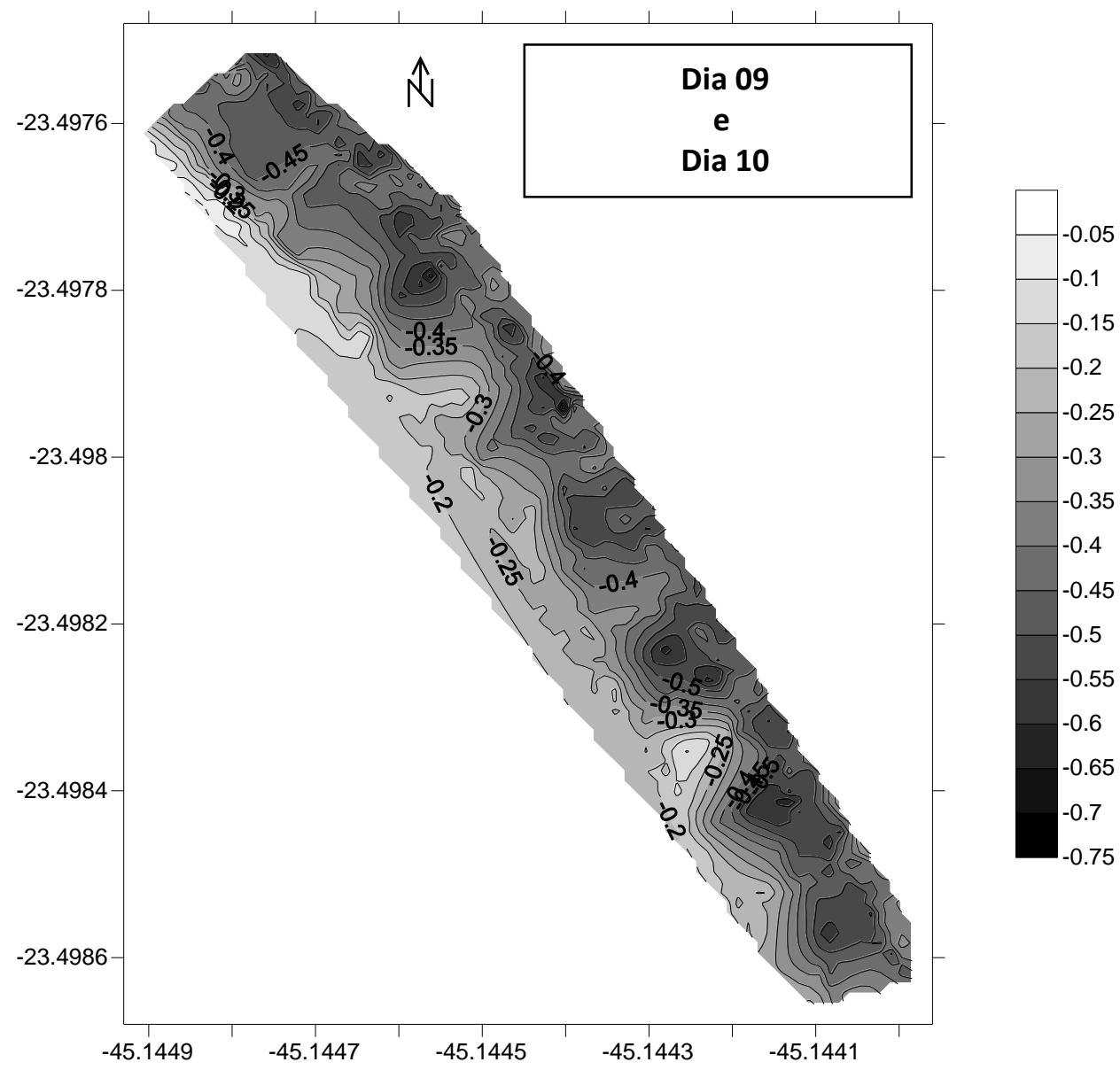

Figura 39 Gráfico de variação topográfica entre os dias 09 e 10 de Julho de 2012. 


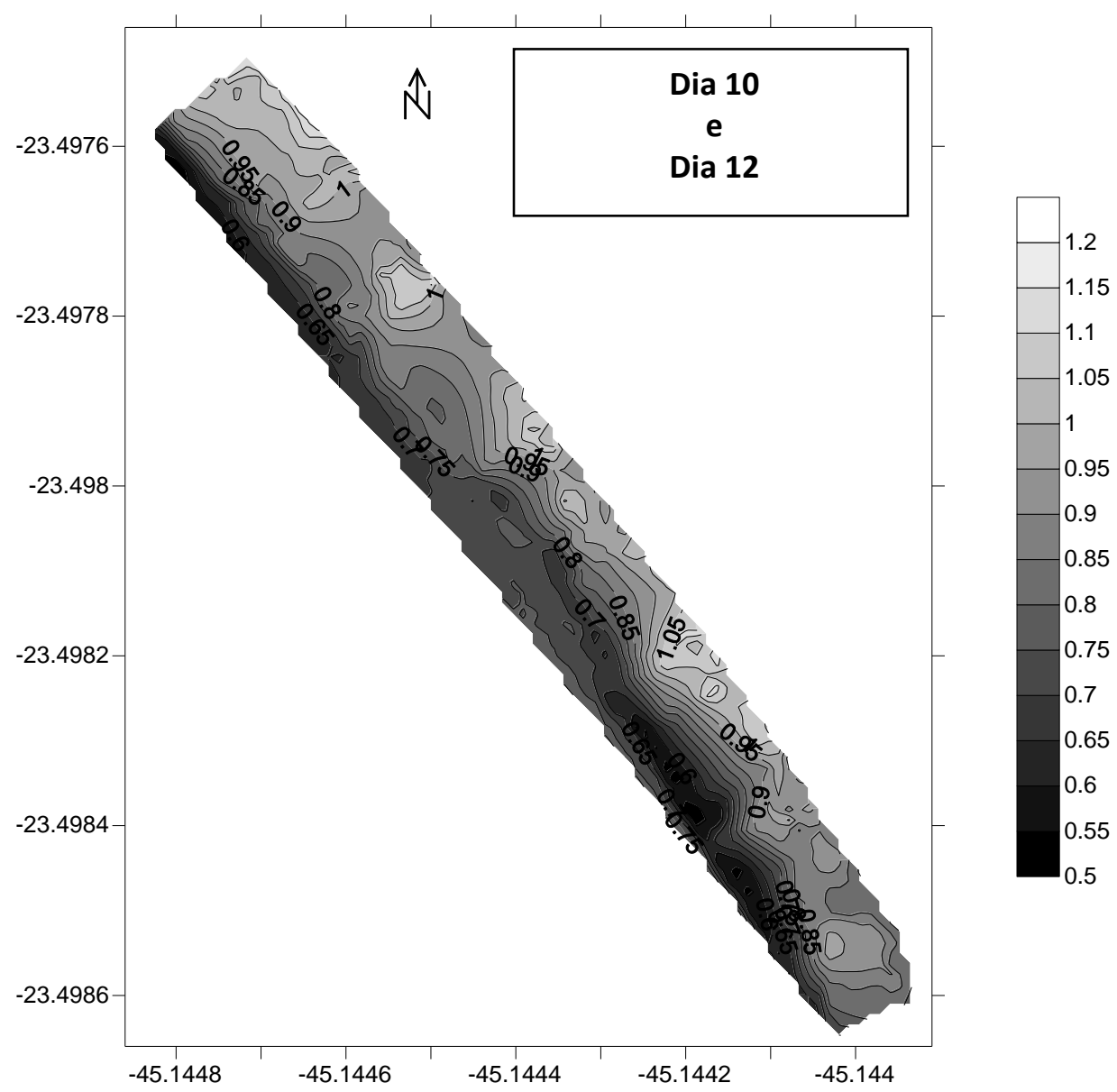

Figura 40 Gráfico de variação topográfica entre os dias 10 e 12 de Julho de 2012. 


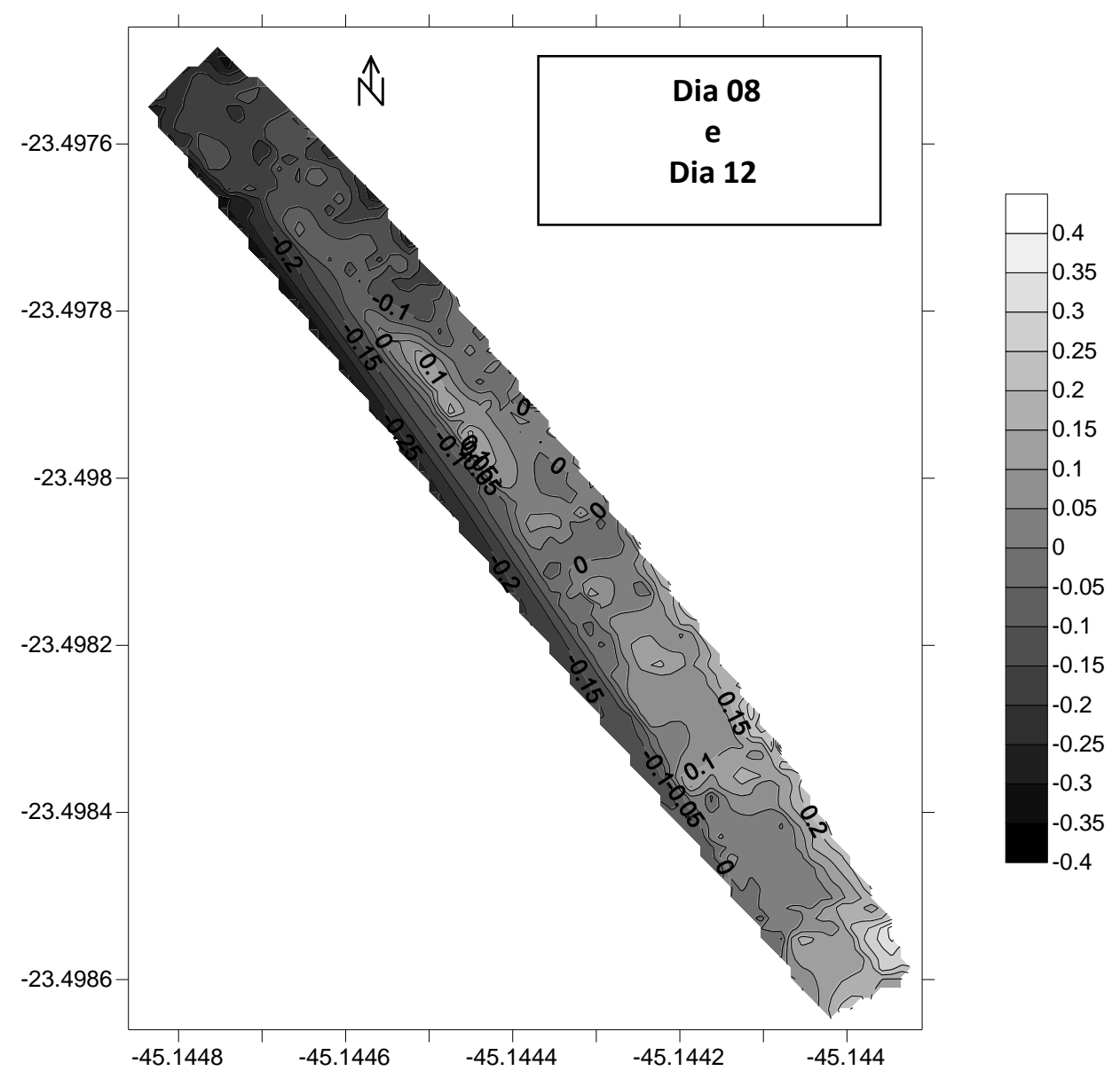

Figura 41 Gráfico de variação topográfica entre os dias 08 e 12 de Julho de 2012.

Os levantamentos executados no período de Agosto de 2012 indicaram que do dia 29 para 30 (Fig.42), a variação sedimentar do trecho foi positiva, com variação de $0,7 \mathrm{~m}$ a $-0,05 \mathrm{~m}$. A parte central do trecho foi a que apresentou os maiores ganhos sedimentares, sendo eles entre $0,7 \mathrm{~m}$ e $0,2 \mathrm{~m}$. A linha d'água e o limite superior e a linha d'água tiveram um ganho menor, variando entre 0,3 e $0,05 \mathrm{~m}$. Do dia 30 para 31 (Fig.43) o trecho obteve variação negativa $(-0,65 \mathrm{~m}$ a $0,1 \mathrm{~m})$, sendo que as maiores perdas ocorreram nas cúspides praiais na área a oeste e centro do trecho $(0,65 \mathrm{~m}$ a 0,3m). A linha d'água se apresentou estável espacialmente. 
A praia da Domingas Dias durante todo o período amostrado (Fig.44) apresentou perda sedimentar, com uma estabilidade espacial maior do último dia em relação ao primeiro na linha d'água, seguido por ganhos sedimentares nas cúspides praiais $(0,3 \mathrm{~m}$ a $0,05 \mathrm{~m})$, e perda sedimentar entre $-0,1 \mathrm{~m}$ e $-0,35 \mathrm{~m}$ no limite superior do trecho. A variação volumétrica total foi de $-182,11 \mathrm{~m}^{3}$.

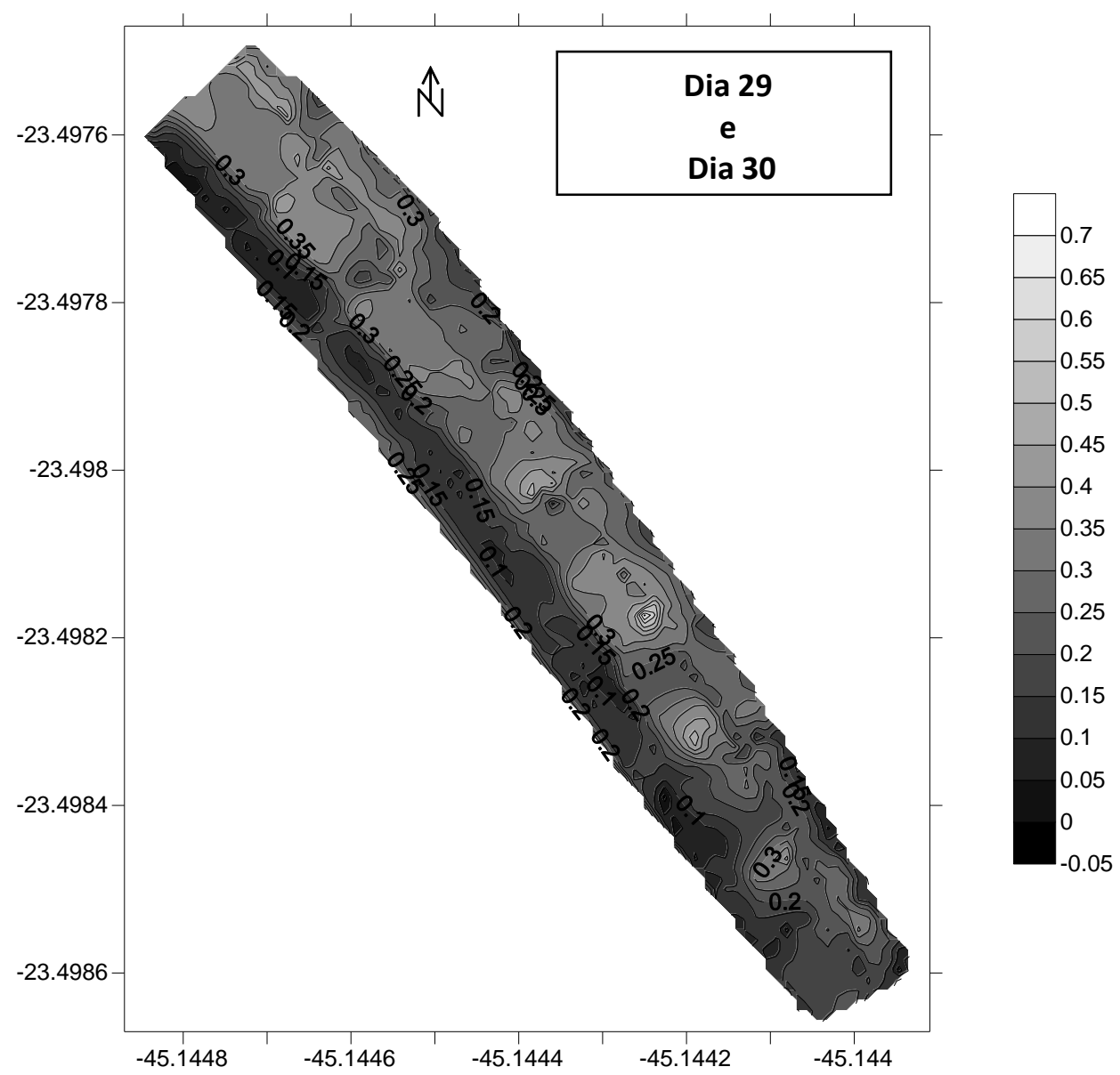

Figura 42 Gráfico de variação topográfica entre os dias 29 e 30 de Agosto de 2012. 


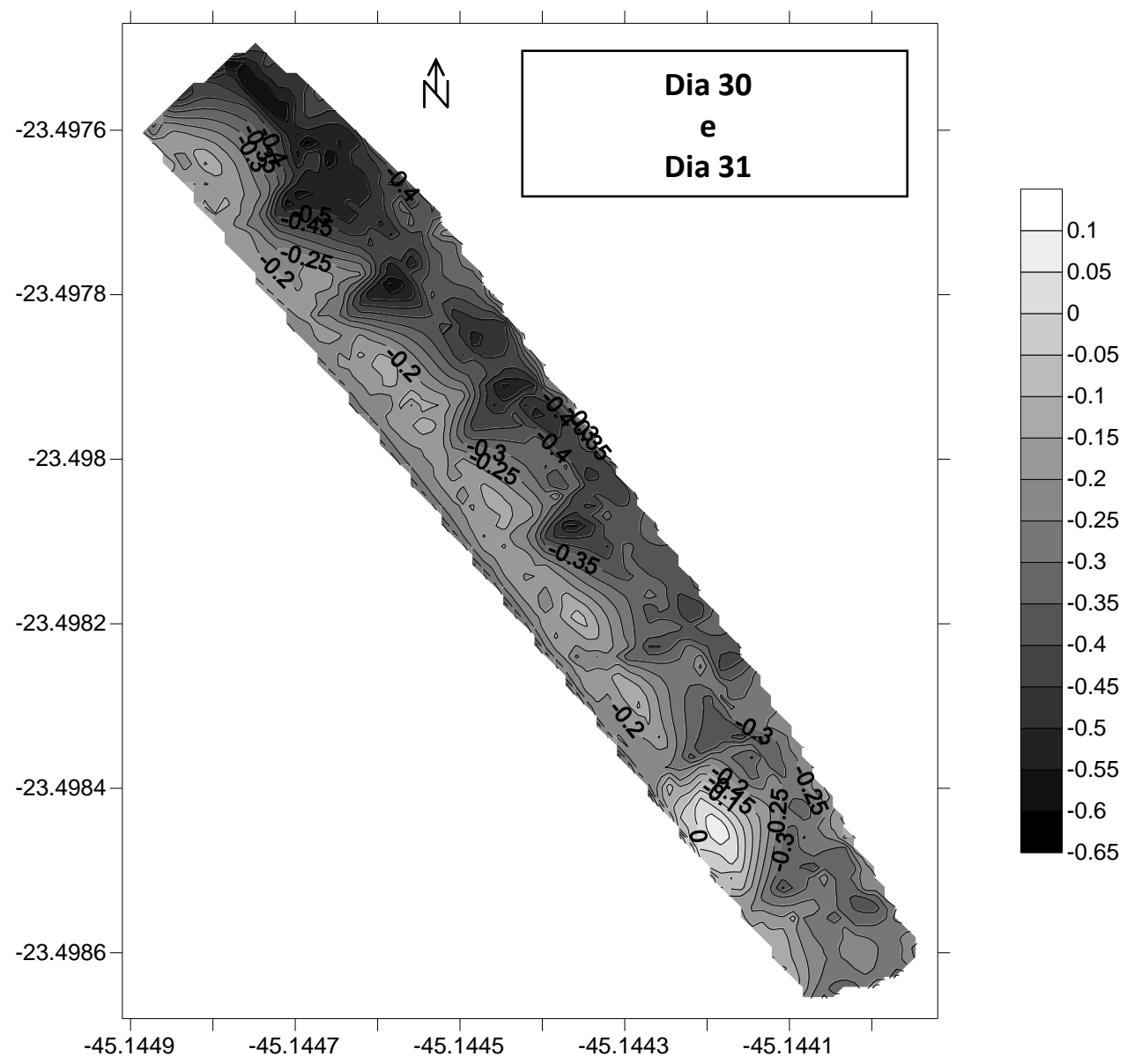

Figura 43 Gráfico de variação topográfica entre os dias 30 e 31 de Agosto de 2012. 


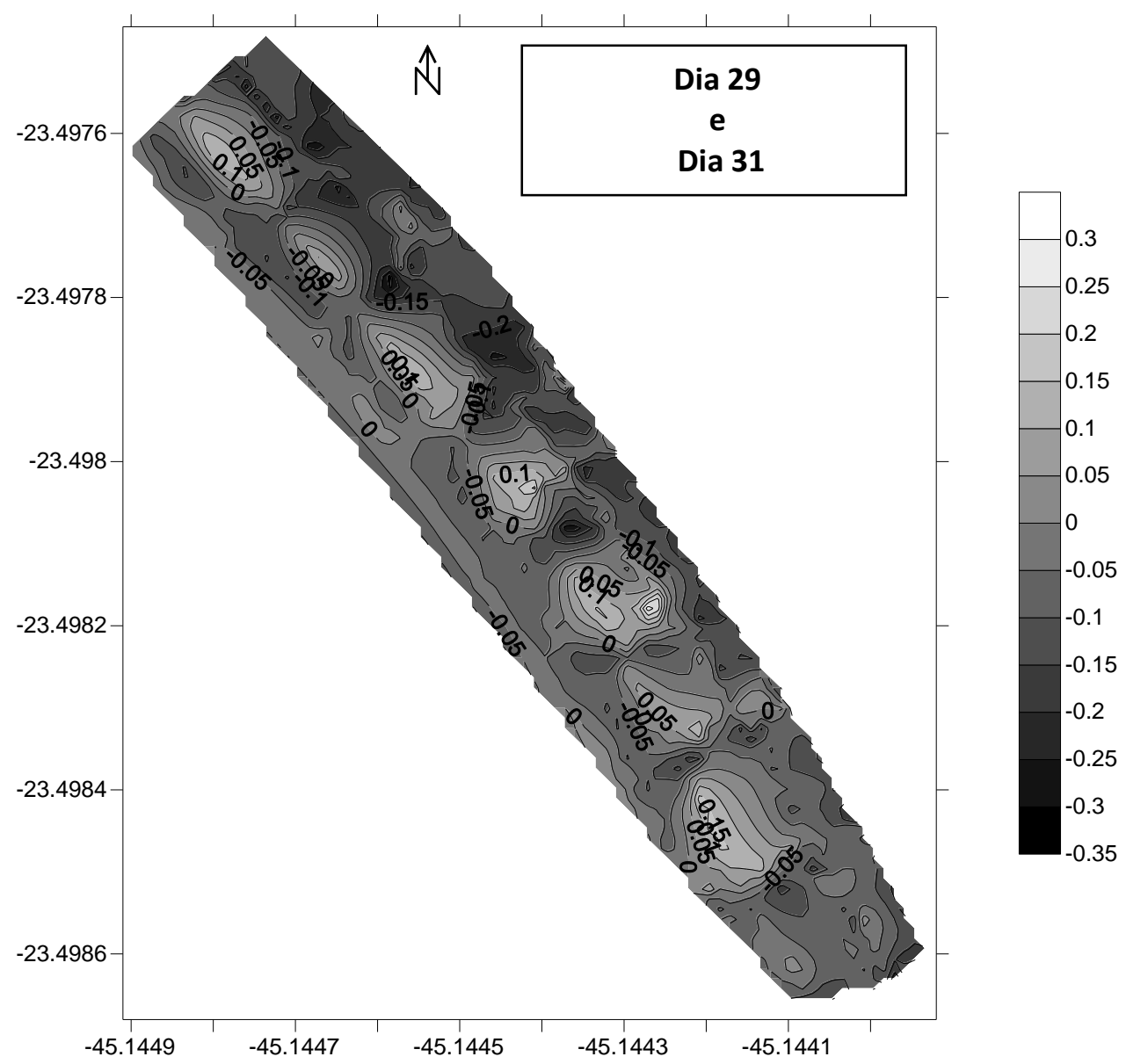

Figura 44 Gráfico de variação topográfica entre os dias 29 e 31 de Agosto de 2012.

$\mathrm{Na}$ análise comparativa entre os meses de Junho e Julho (Fig.45), verificou-se que o perfil variou entre $1.25 \mathrm{~m}$ e $0,25 \mathrm{~m}$, apresentando características deposicionais. A área a oeste do trecho foi a que apresentou maiores ganhos $(1,25 \mathrm{~m}$ a 0,8$)$, a parte central $(0,8 \mathrm{~m}$ a $0,7 \mathrm{~m})$ o limite superior $(0,7 \mathrm{~m}$ a 0,5$)$, e a área a leste menor variação $(0,5 \mathrm{~m}$ a $0,25 \mathrm{~m})$.

A mesma análise entre os meses de Julho e Agosto (Fig.46) mostrou uma predominância de perda sedimentar para o trecho, com variações altimétricas entre $-1,0$ $\mathrm{m}$ e $-0,08 \mathrm{~m}$. As perdas ocorreram de maneira crescente do limite superior da praia no sentido da linha d’água. A área a leste permaneceu mais estável que a área a oeste. 
O perfil do período total estudado, entre o primeiro dia de levantamento no mês de Junho e o último dia de levantamento no mês de Agosto (Fig.47), apresentou uma variação total negativa para a Praia da Domingas Dias com variação altimétrica entre $0,25 \mathrm{~m}$ e $-1,25 \mathrm{~m}$. As perdas sedimentares deram-se de maneira regular, com as maiores perdas sedimentares junto à linha d'água, sendo decrescente da área oeste para a área leste. As cúspides de uma maneira geral, tiveram a maior variação, se apresentando mais instáveis. A variação total de volume encontrada foi de $-388,26 \mathrm{~m}^{3}$.

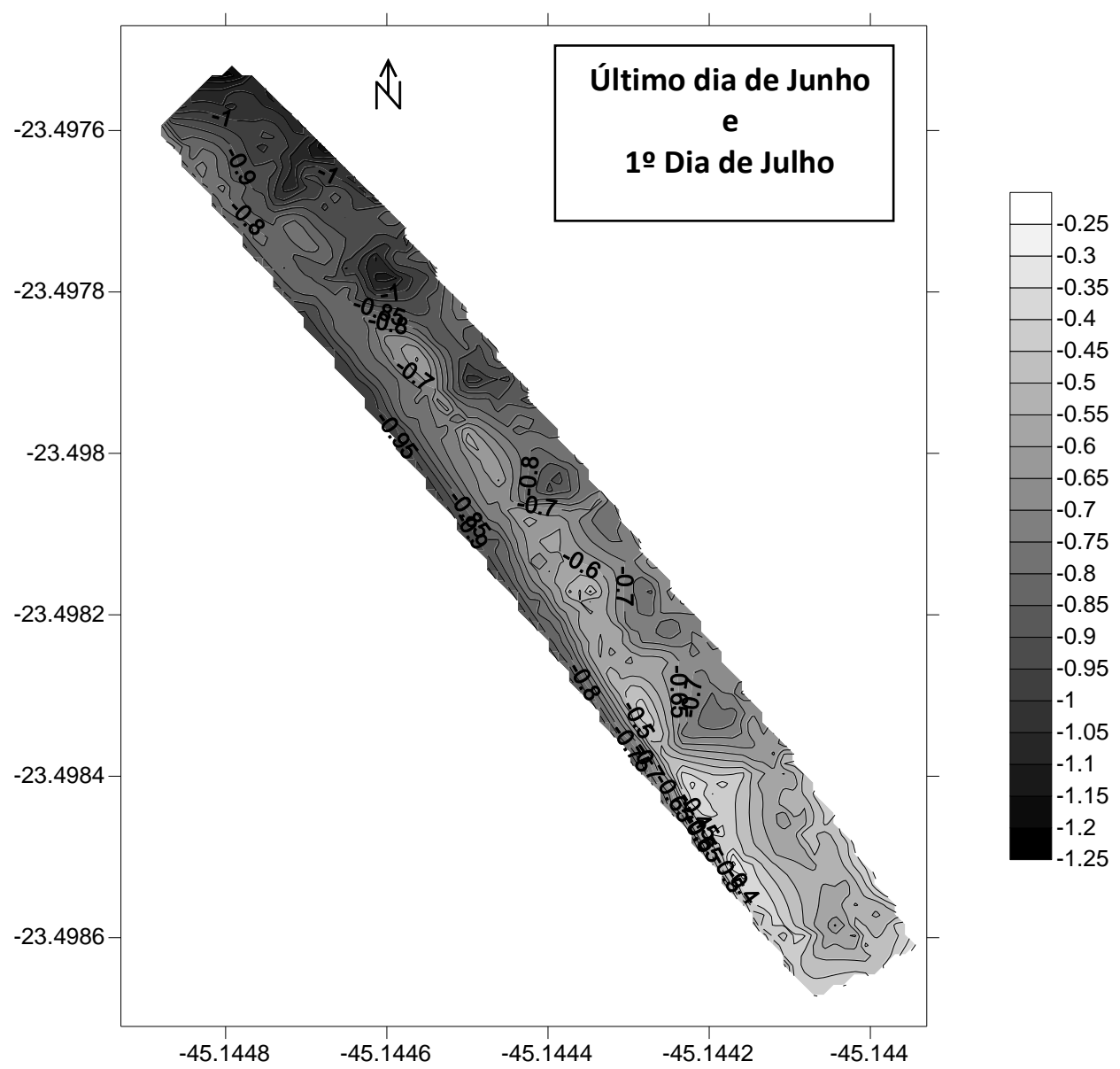

Figura 45 Gráfico de variação topográfica entre o último dia de junho e o primeiro dia de Julho de 2012. 


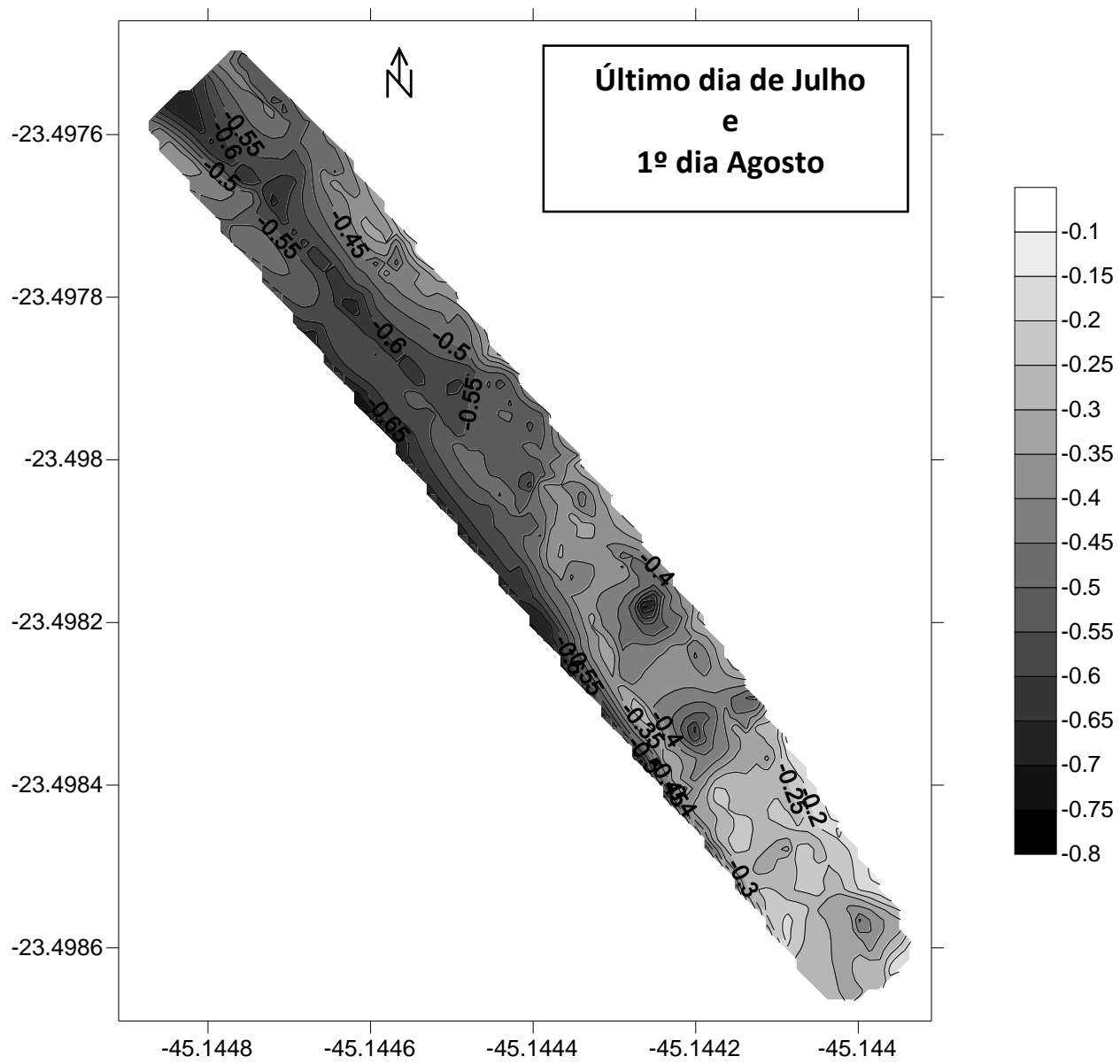

Figura 46 Gráfico de variação topográfica entre o último dia de julho e o primeiro dia de Agosto de 2012. 


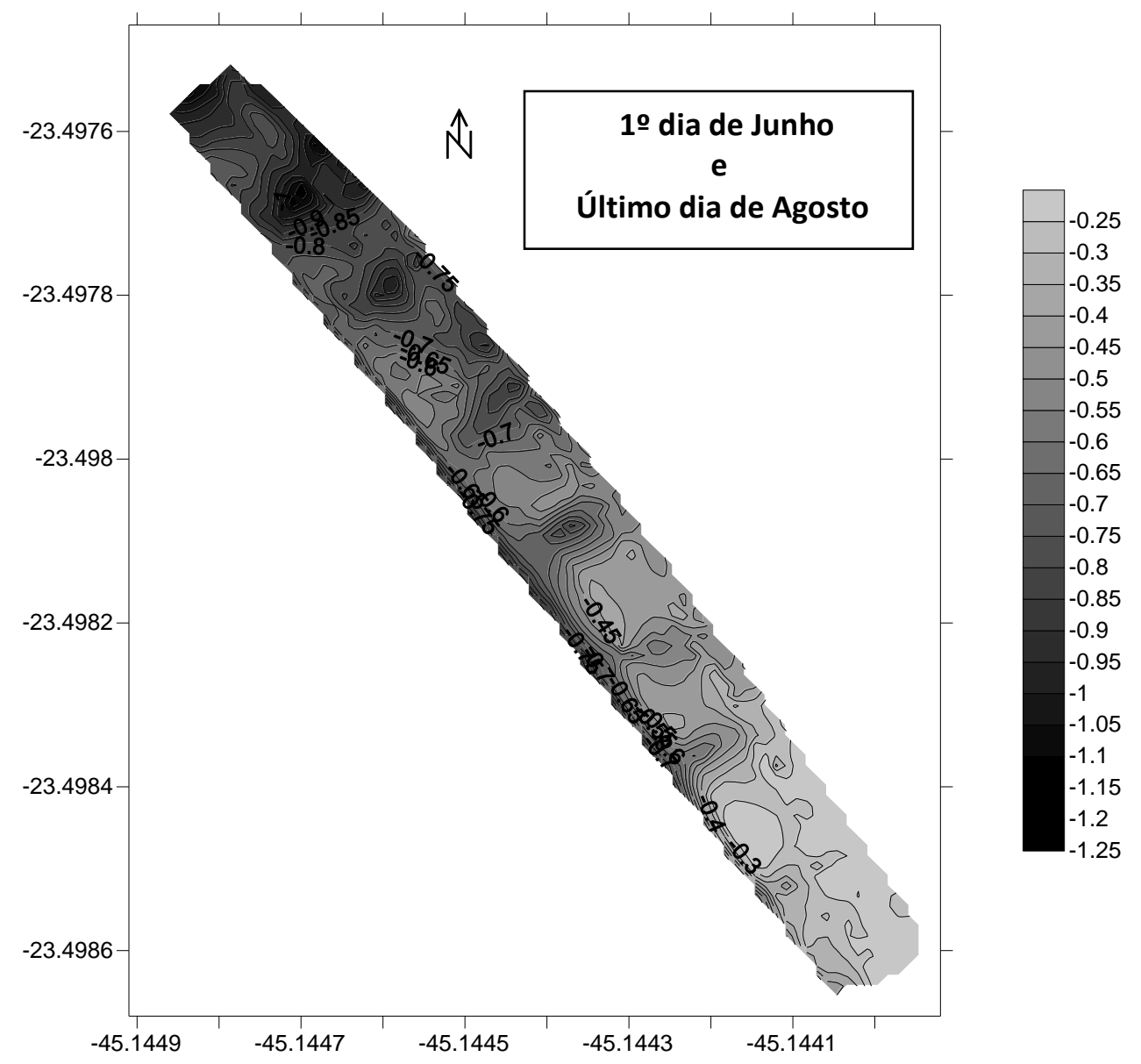

Figura 47 Gráfico de variação topográfica entre o primeiro dia de junho e o último dia de Agosto de 2012.

\subsubsection{Praia da Sununga}

Por conta da grande variação da posição espacial da linha d'água na Praia da Sununga durante as campanhas, foi impossível estimar com precisão a variação do volume sedimentar, já que para isso é necessário uma área conhecida e de igual dimensão para comparação.

Ao longo do período foi possível identificar a migração de dois bancos para a área a leste. A maior variação topográfica de perda sedimentar encontrada durante o período foi de $-2,10$ m entre o dia 29 e 31 do mês de Agosto e a maior variação de ganho sedimentar foi de $1,5 \mathrm{~m}$, entre o dia 10 e 12 de Julho. 
Na praia da Sununga foi observada uma grande variação topográfica do arco praial, predominando uma tendência de decréscimo altimétrico. De maneira geral, no período amostrado, o setor oeste apresentou predomínio deposicional, enquanto o setor oposto do arco praial (Leste) a tendência predominante foi de perda (erosão). Porém, quando considerado todo o período monitorado, observou-se uma perda em todo o arco praial com maior destaque no setor leste da praia, comparativamente a uma maior estabilidade temporal no setor mais a oeste.

Os levantamentos realizados no período de Junho de 2012 indicaram que do dia 20 para o dia 21 (Fig.48), o trecho amostrado da praia mostrou uma grande variação, que ocorreu entre $0,6 \mathrm{~m}$ e $-0,55 \mathrm{~m}$. Muitos pontos ao longo do trecho apresentaram estabilidade e os ganhos sedimentares foram maiores junto à linha d'água. Foi possível observar dois bancos emersos no prisma praial, com perda sedimentar $(-0,55 \mathrm{~m})$ e três bancos com ganho sedimentar, dois bancos de $0,6 \mathrm{~m}$ e outro banco de $0,25 \mathrm{~m}$. Do dia 21 para o dia 22 (Fig.49). Os bancos migraram no sentido a área a leste, ou seja os bancos apresentaram tendência erosiva nesse sentido. Do dia 22 para o dia 23 (Fig.50) de Junho as variações foram entre $0,7 \mathrm{~m}$ e $-0,5 \mathrm{~m}$. com tendência erosiva na área a leste e deposicional na área a oeste. Foi observada a presença de um banco na área a oeste $(0,7 \mathrm{~m})$ e a formação de três bancos na área a leste com perdas sedimentares de até 0,5m. A parte superior da praia se mostrou estável, sem variação em todo o trecho e as maiores variações foram encontradas em bancos próximos à linha d'água.

A Praia da Sununga durante o período amostrado (Fig.51) mostrou uma grande variação, $0,75 \mathrm{~m}$ a $-0,55 \mathrm{~m}$, com presença de bancos com tendência migratória para a área leste. A área do trecho a oeste do prisma praial apresentou características deposicionais, enquanto o setor a leste características erosivas. O limite superior da 
praia se comportou de maneira estável, enquanto a linha d'água apresentou grandes variações espaciais.

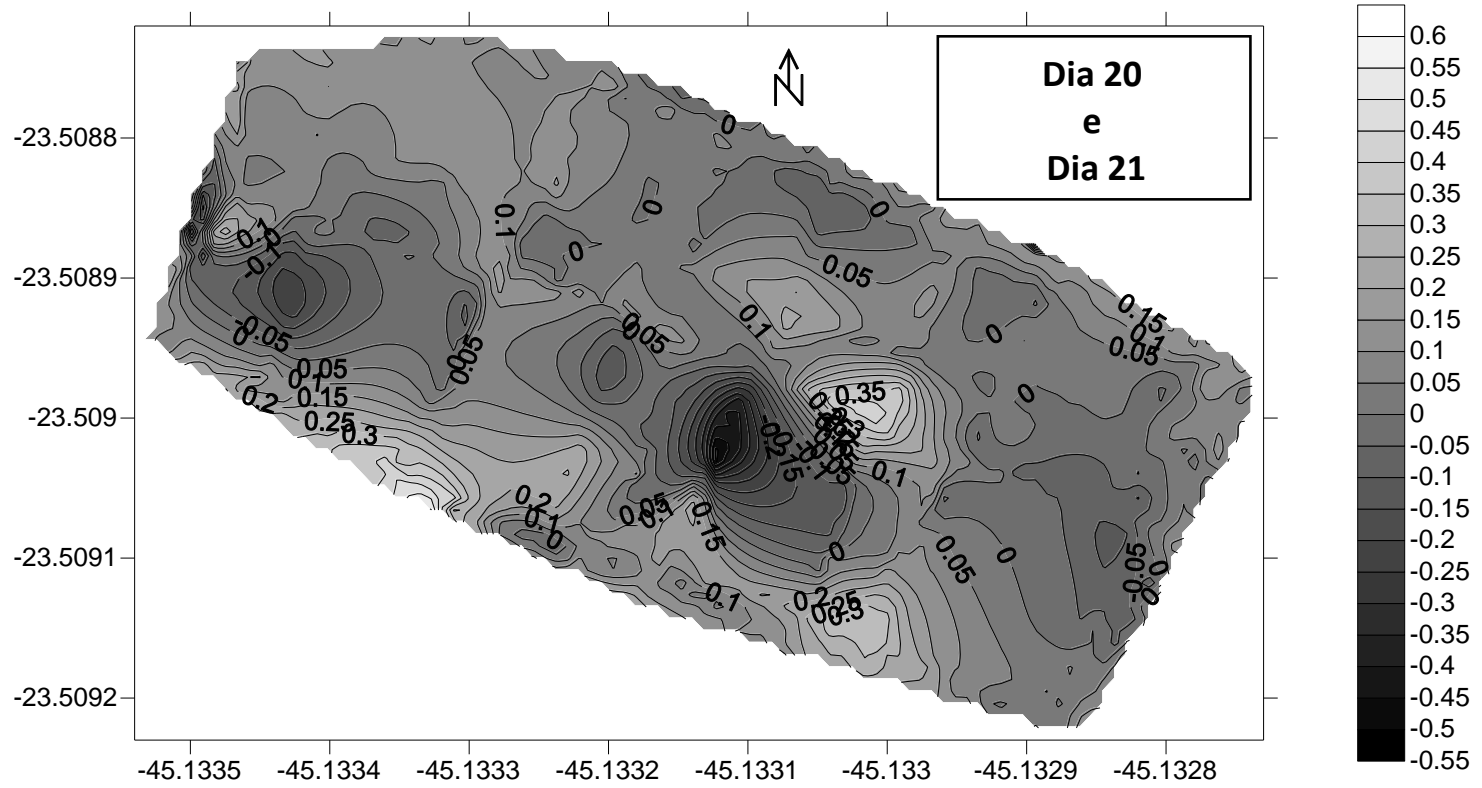

Figura 48 Gráfico de variação topográfica entre os dias 20 e 21 de junho de 2012 para a praia da Sununga.

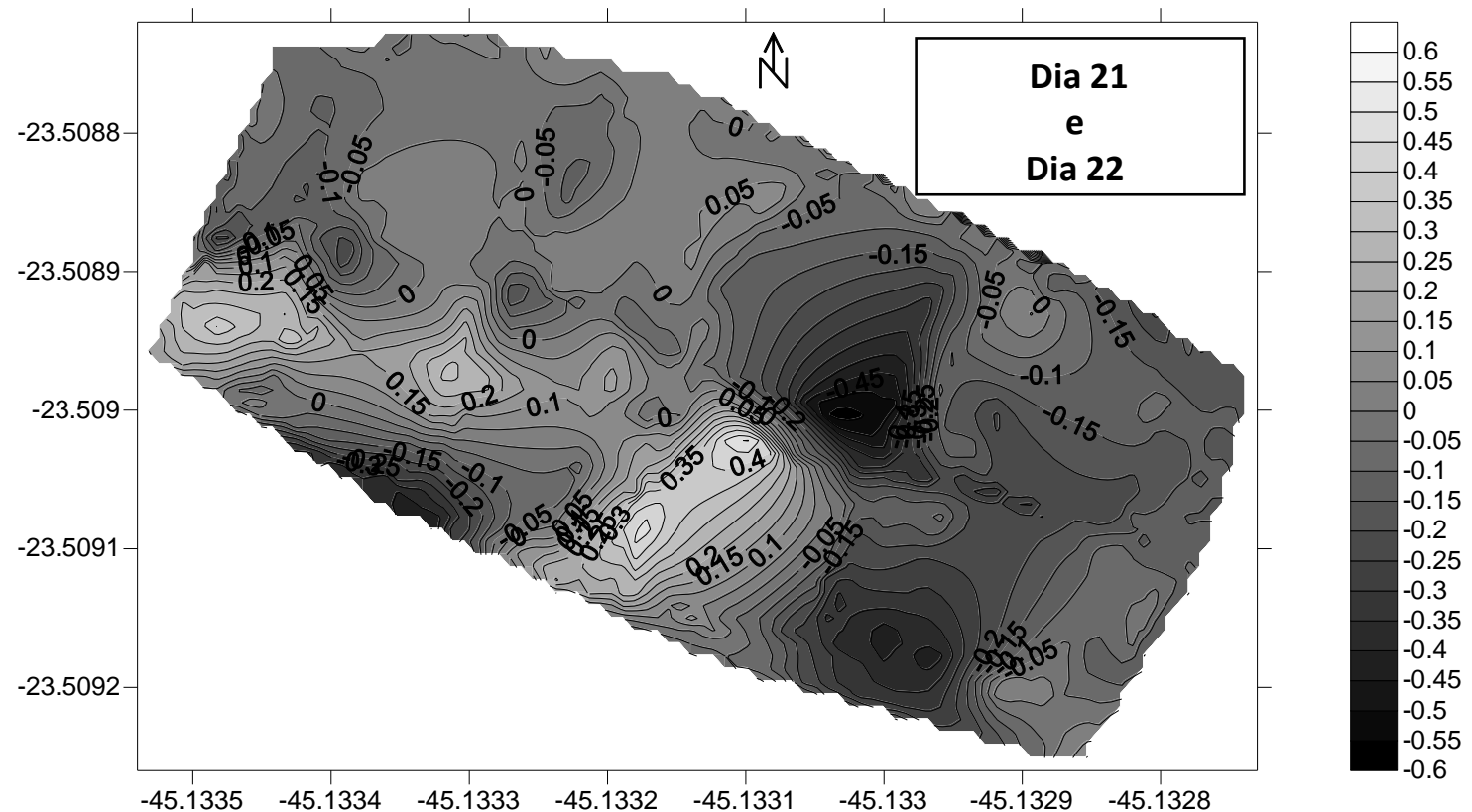

Figura 49 Gráfico de variação topográfica entre os dias 21 e 22 de junho de 2012 para a praia da Sununga. 


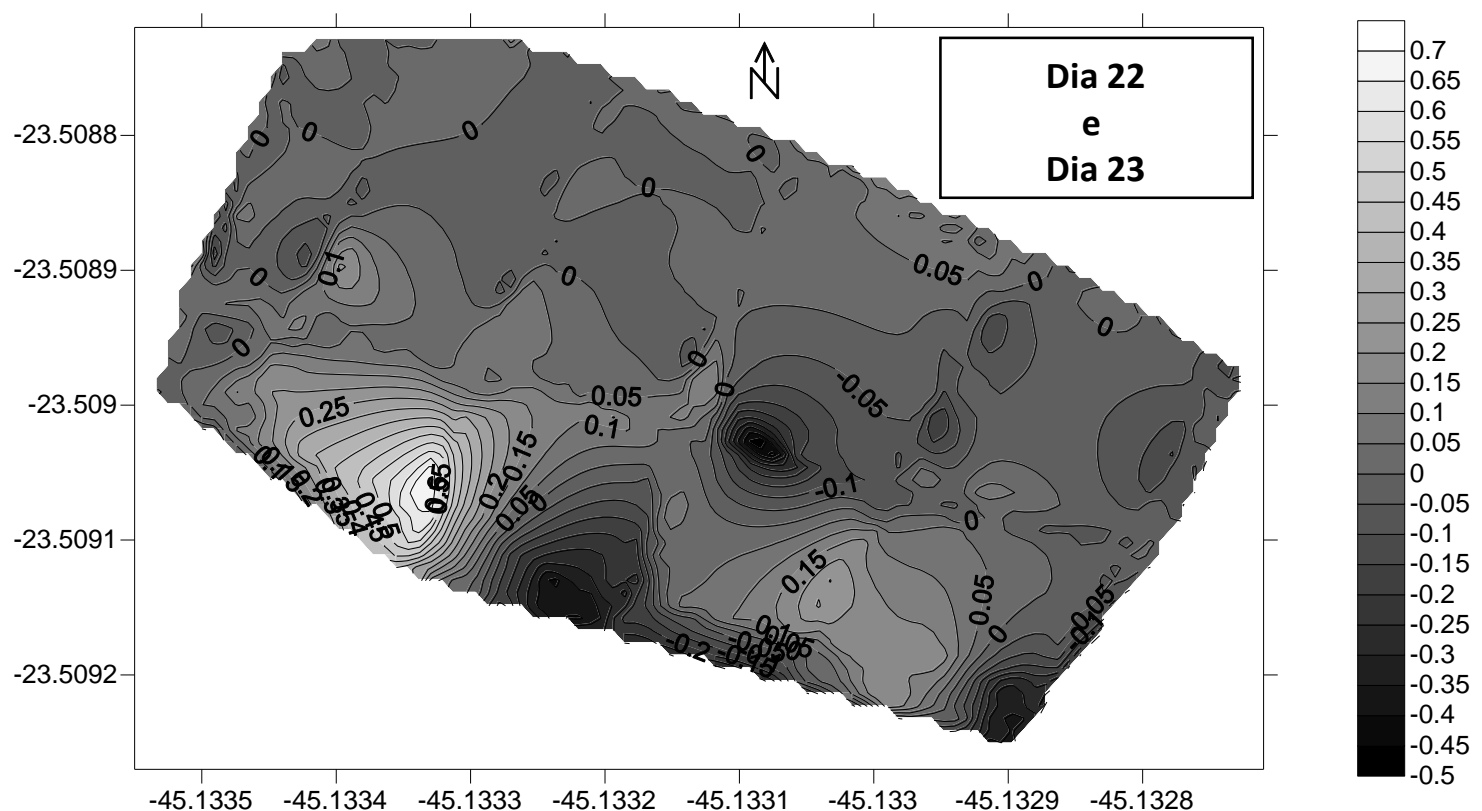

Figura 50 Gráfico de variação topográfica entre os dias 22 e 23 de junho de 2012 para a praia da Sununga.

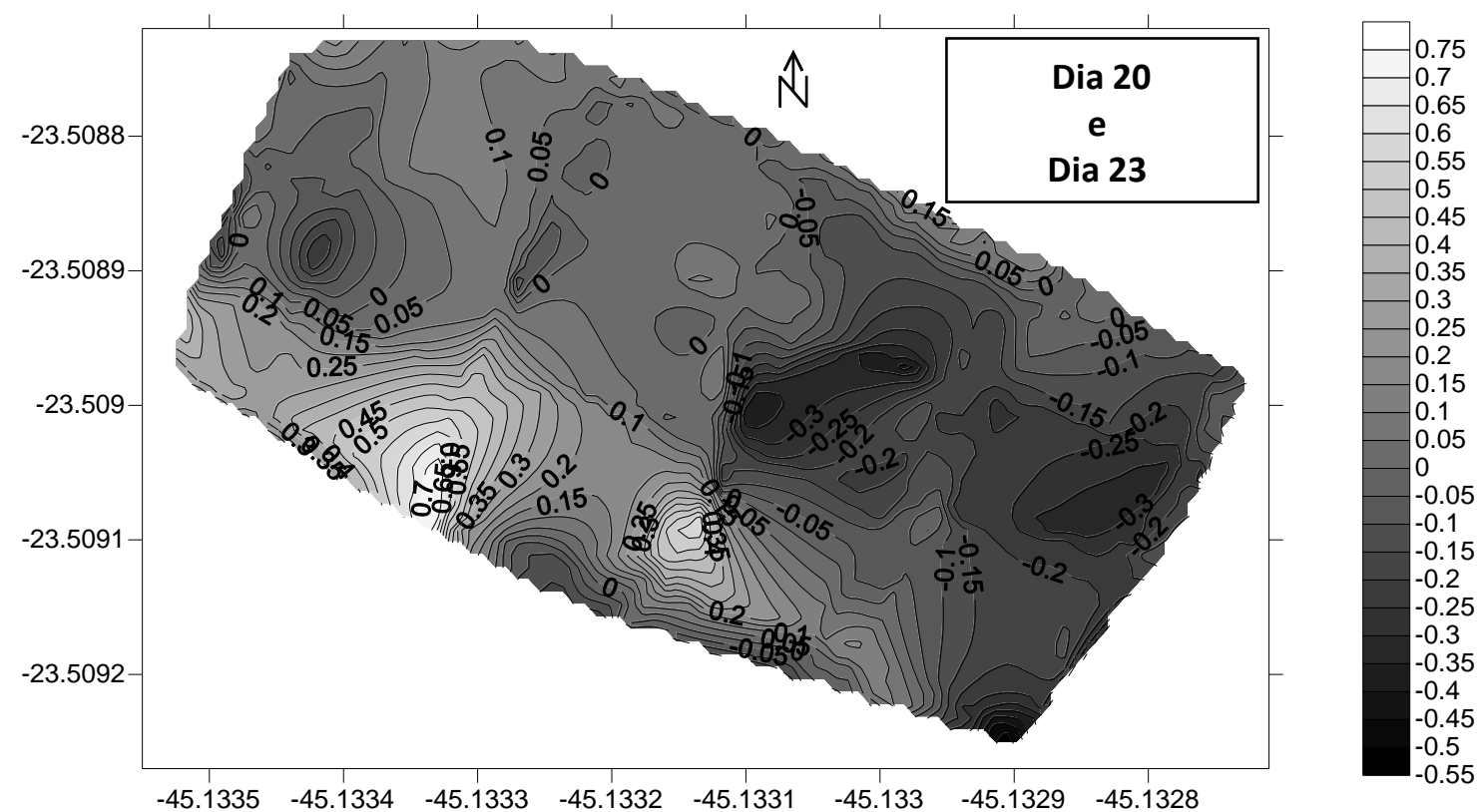

Figura 51 Gráfico de variação topográfica entre os dias 20 e 23 de junho de 2012 para a praia da Sununga.

Os levantamentos obtidos no período de Julho de 2012 indicaram que do dia 09 para o dia 10 (Fig.52) a variação sedimentar foi negativa $(0,1 \mathrm{~m}$ e $-2 \mathrm{~m})$. Foi possível observar uma perda crescente da área a oeste para a área a leste. O perfil do trecho 
amostrado do dia 12 para o dia 10 (Fig.53) apresentou ganho sedimentar em toda a sua extensão $(1,5 \mathrm{~m}$ a $0 \mathrm{~m})$. A linha d'água apresentou os maiores valores positivos, com ganho sedimentar entre $1,5 \mathrm{~m}$ e $1 \mathrm{~m}$. No restante do trecho o ganho sedimentar foi menor $(0,2 \mathrm{~m}$ a $0,7 \mathrm{~m})$. Do dia 13 para 12 (Fig.54) as variações foram entre $0,85 \mathrm{~m}$ e $-0,35 \mathrm{~m}$. A parte superior da área a oeste se manteve estável, com perda apenas no seu canto mais extremo, sendo que e a maior parte do trecho variou entre $0,3 \mathrm{~m}$ e $0,1 \mathrm{~m}$. Na parte central observaram-se o maior ganho sedimentar que variou entre $0,4 \mathrm{~m}$ e $0,85 \mathrm{~m}$.

Em sua totalidade (Fig.55), o trecho apresentou ganho sedimentar, com perda sedimentar apenas no extremo da área a leste. O restante do trecho se manteve mais estável com maiores deposições na linha d'água $(0,1 \mathrm{~m}$ a $0,8 \mathrm{~m})$.

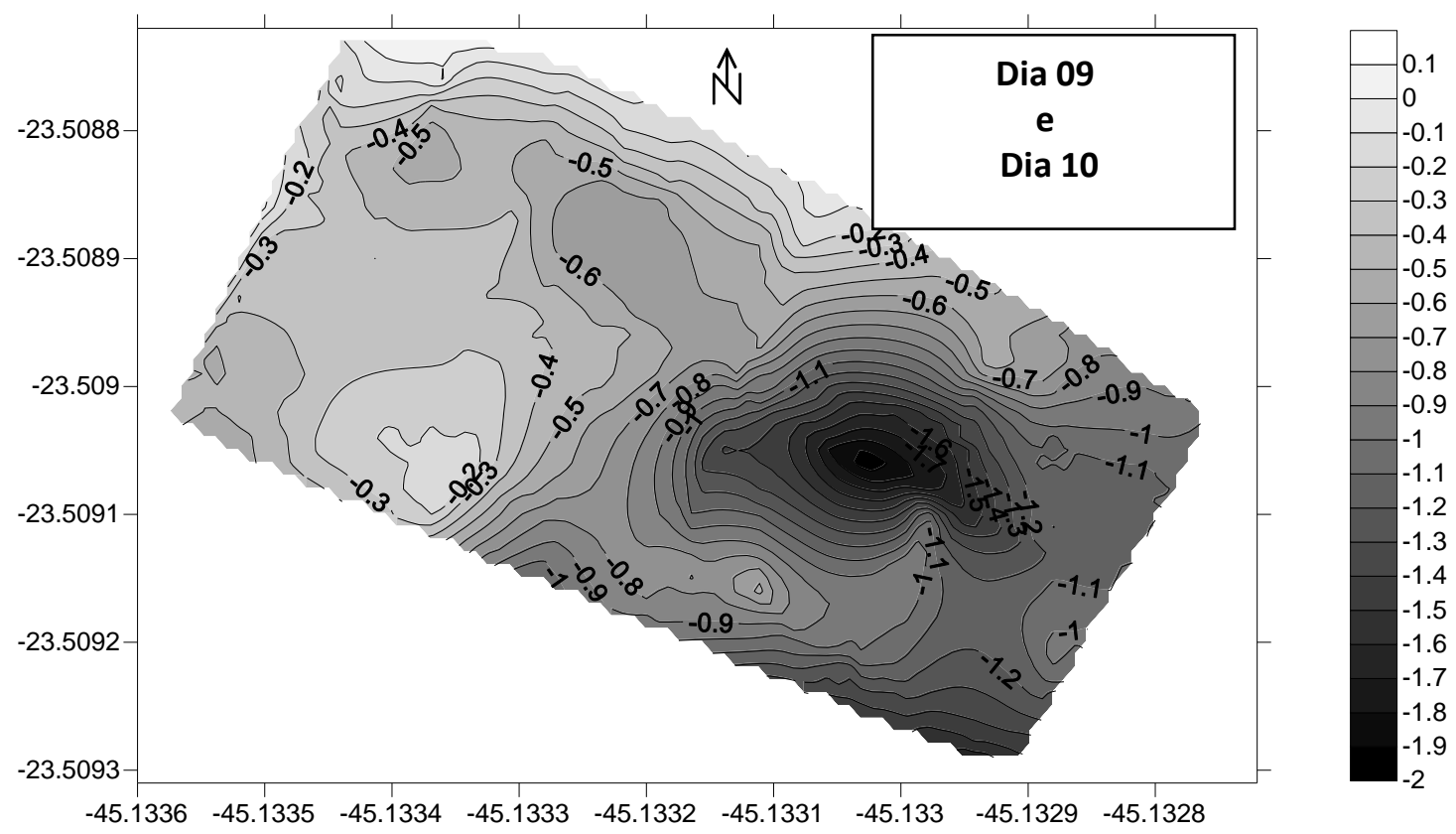

Figura 52 Gráfico de variação topográfica entre os dias 09 e 10 de julho de 2012 para a praia da Sununga. 


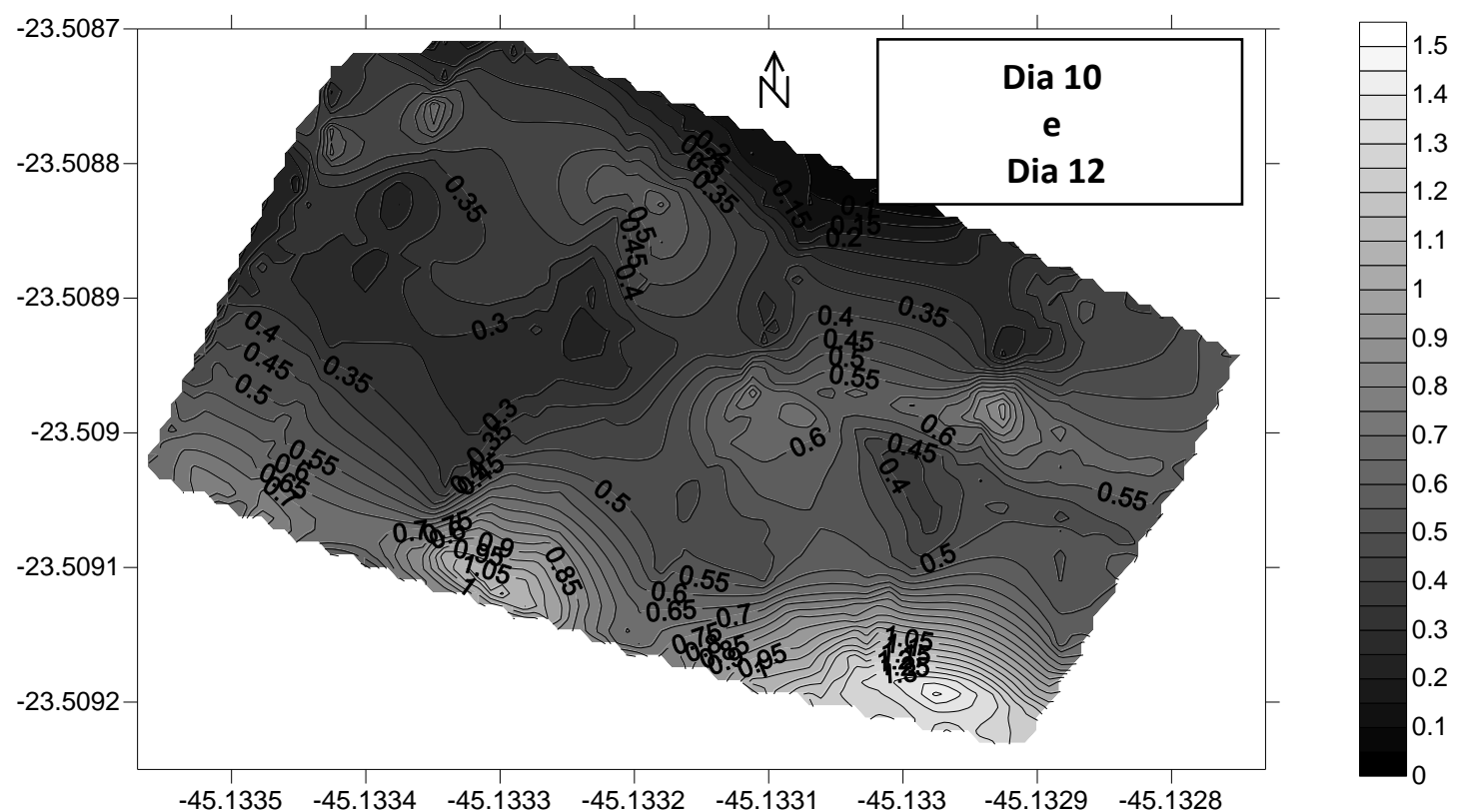

Figura 53 Gráfico de variação topográfica entre os dias 10 e 12 de julho de 2012 para a praia da Sununga.

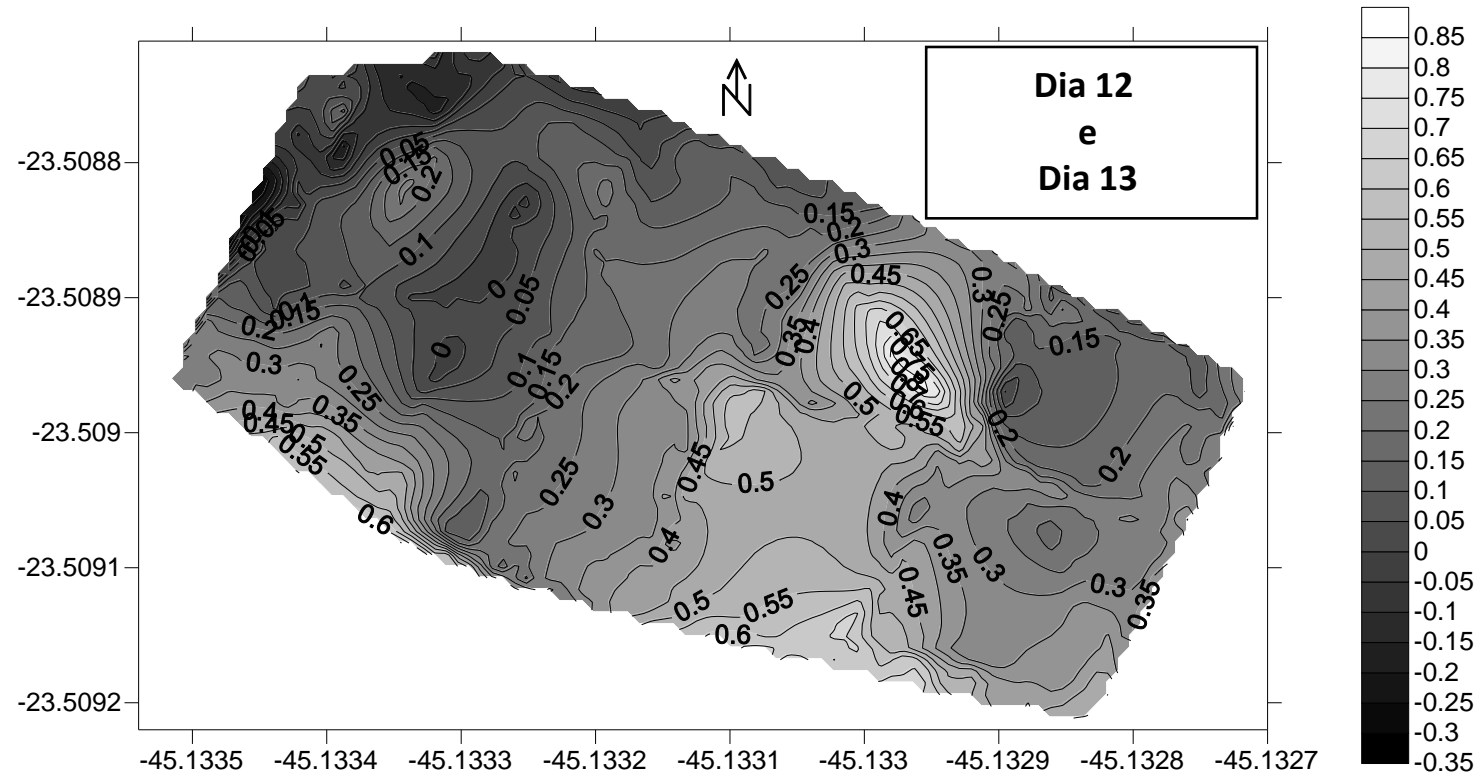

Figura 54 Gráfico de variação topográfica entre os dias 12 e 13 de julho de 2012 para a praia da Sununga. 


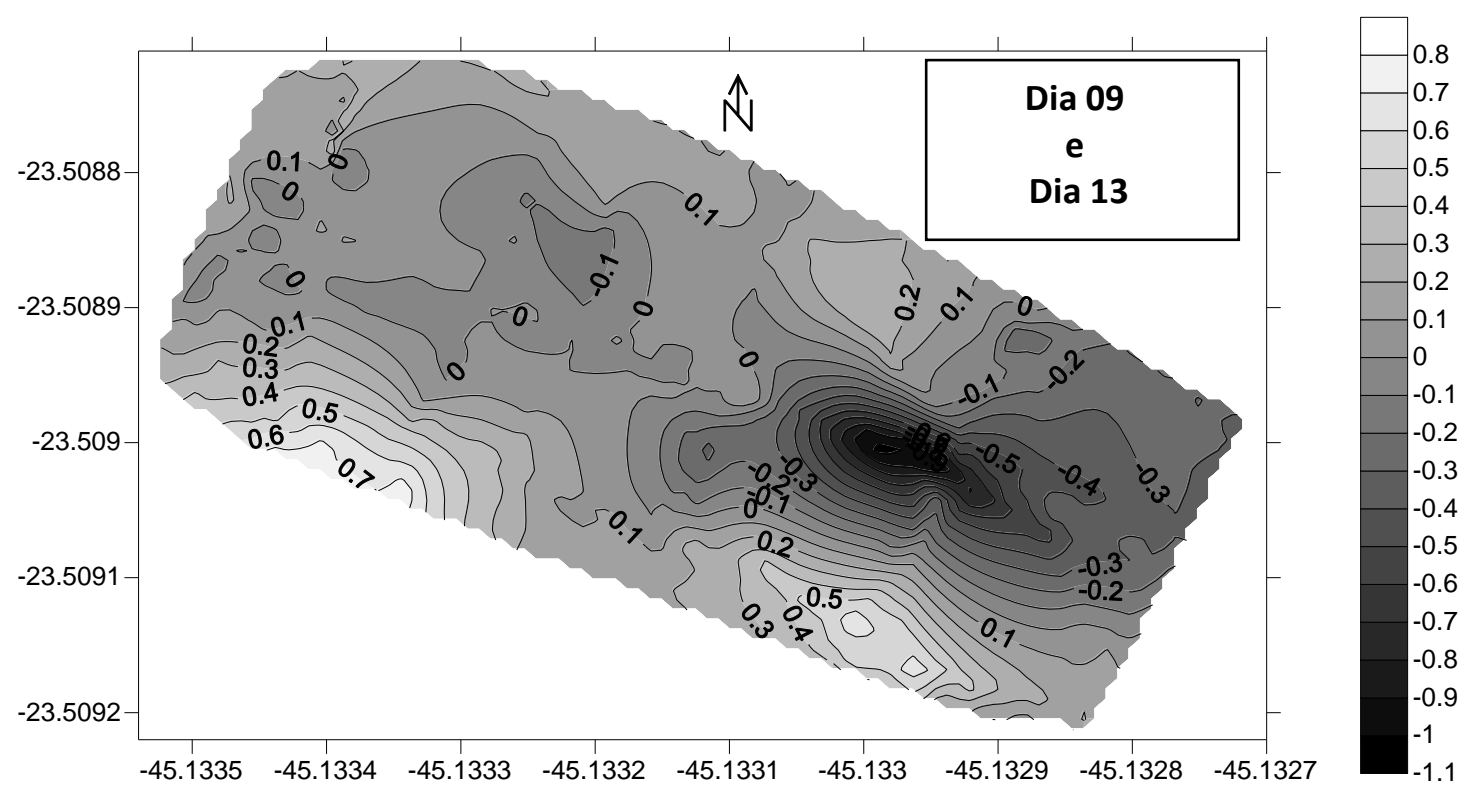

Figura 55 Gráfico de variação topográfica entre os dias 09 e 13 de julho de 2012 para a praia da Sununga.

Os levantamentos realizados no período de Agosto de 2012 indicaram que do dia 28 para 29 (Fig.56) as variações topográficas foram entre $-1,3$ e $0,7 \mathrm{~m}$ com predominante perda sedimentar. Foi possível observar vários pontos estáveis $(0,0 \mathrm{~m})$ ao longo do trecho. A área a oeste foi o ponto com maior ganho de sedimento, principalmente próximo a linha d'água. $\mathrm{O}$ banco com tendência erosiva $(-1,3 \mathrm{~m})$ migrou no sentindo da área a leste, e o restante do perfil se manteve em uma variação entre 0,1m e -0,4m. Do dia 29 e 31 (Fig.57) a variação topográfica foi de $-1,8$ e $0,3 \mathrm{~m}$ que se distribuiu de maneira decrescente da área a oeste para a área a leste. A região próxima à linha d'água apresentou uma perda sedimentar considerável $(-1,2 \mathrm{~m})$ da região central do trecho para a área a leste, o que sugere migração dos bancos no sentido da área a leste.

A praia da Sununga, no trecho amostrado (Fig.58) apresentou para o período, perda sedimentar $(0,3 \mathrm{~m}$ a $-2,1 \mathrm{~m})$. O perfil da área a oeste no sentido da área a leste 
manteve-se estável com $(0,0 \mathrm{~m})$, no extremo da área a oeste e perda sedimentar crescente na direção da área a leste $(-1,7 \mathrm{~m}$ a $-2,2 \mathrm{~m})$.

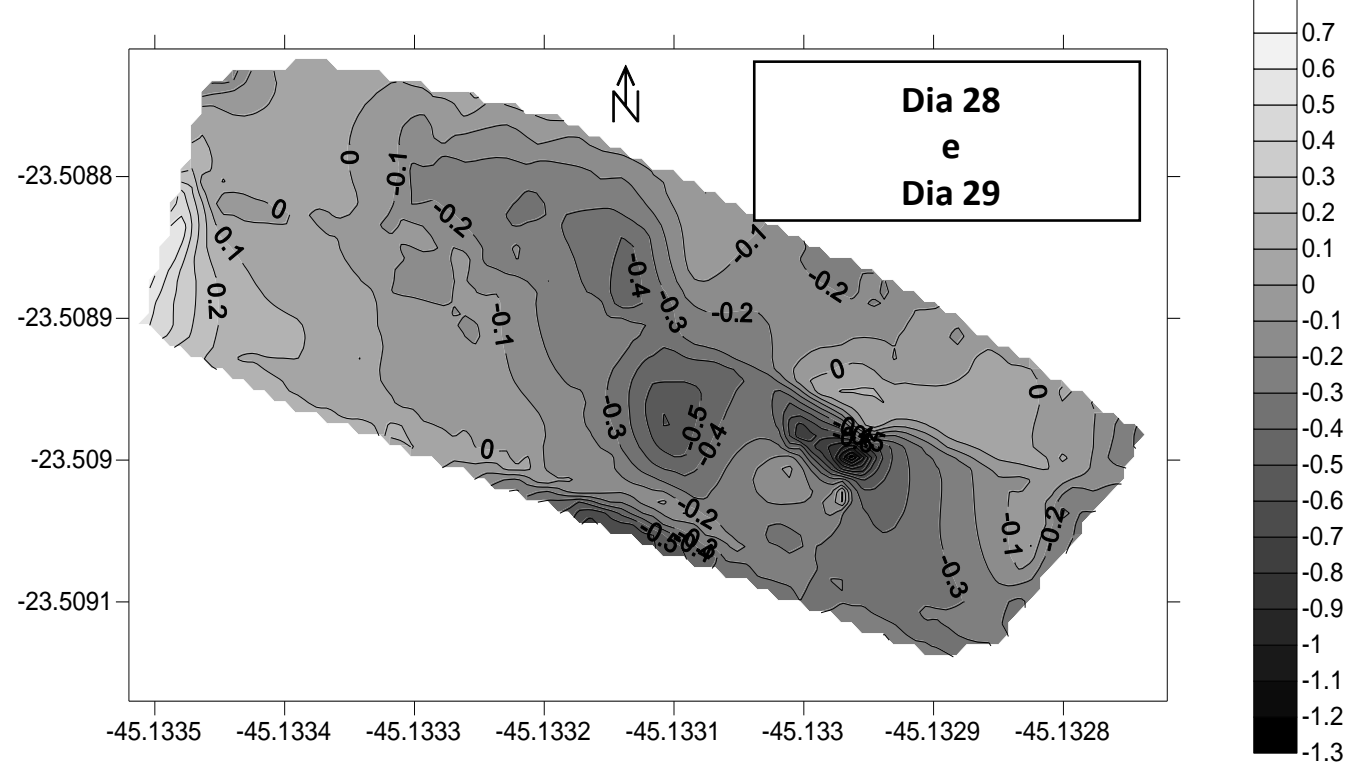

Figura 56 Gráfico de variação topográfica entre os dias 28 e 29 de Agosto de 2012 para a praia da Sununga.

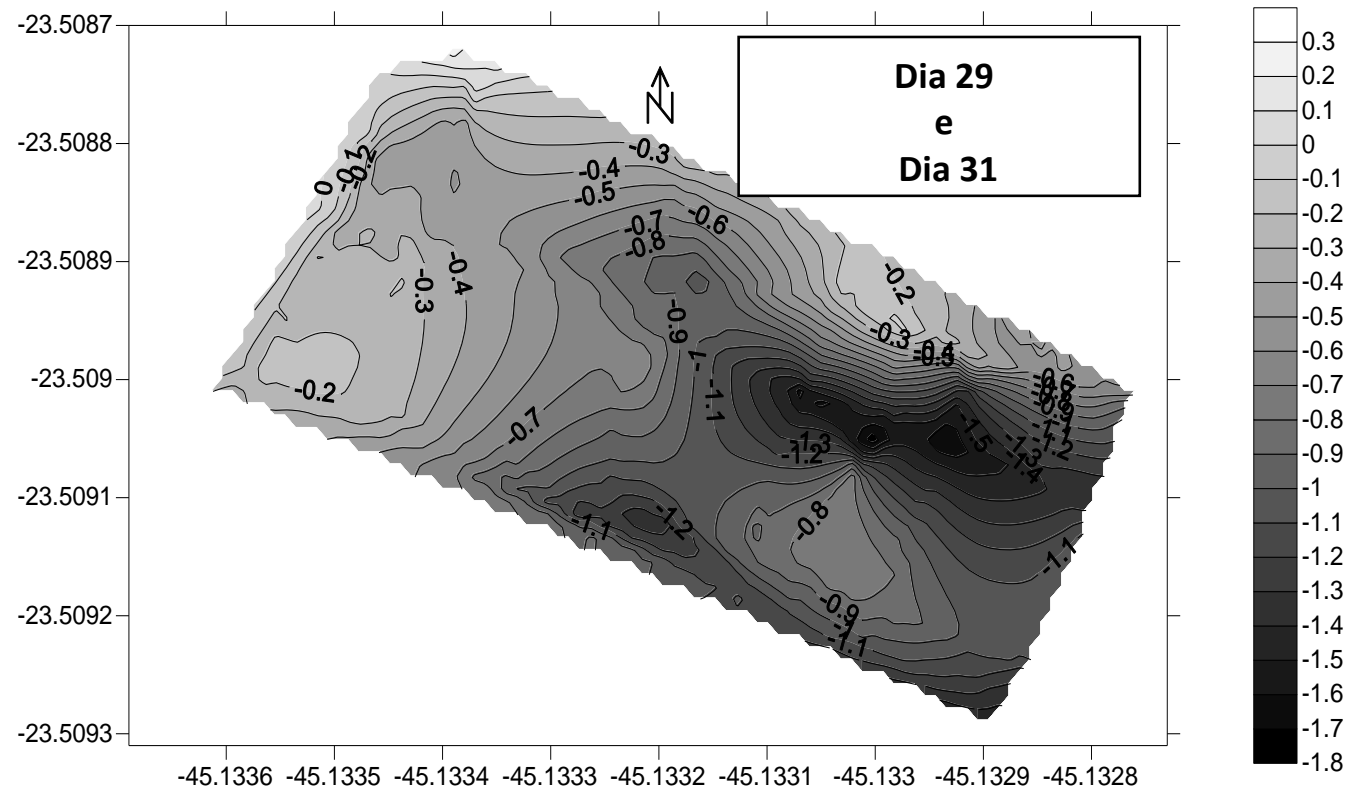

Figura 57 Gráfico de variação topográfica entre os dias 29 e 31 de Agosto de 2012 para a praia da Sununga. 


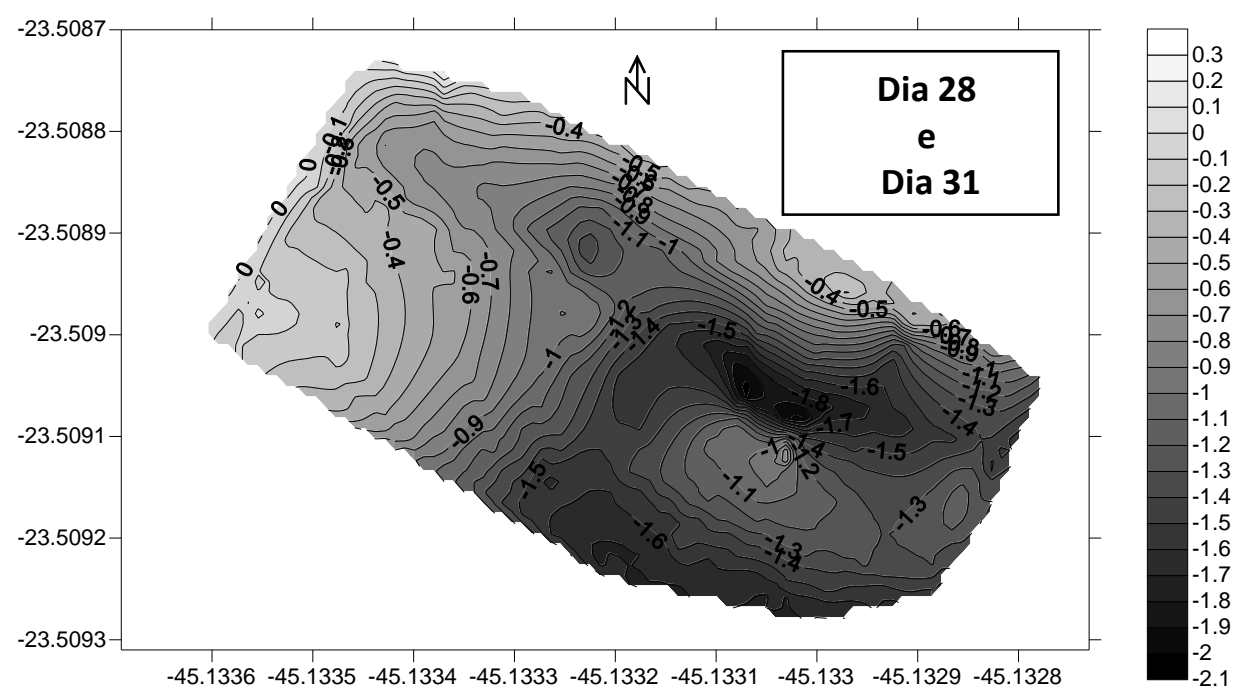

Figura 58 Gráfico de variação topográfica entre os dias 28 e 31 de Agosto de 2012 para a praia da Sununga.

Entre o mês de Junho e o mês de Julho (Fig.59) os perfis apresentaram ganhos sedimentares $(1,3 \mathrm{~m}$ a $-0,5 \mathrm{~m})$. A área a leste foi a com maior ganho de sedimento $(1,3 \mathrm{~m}$ a $0,50 \mathrm{~m})$, e a área a oeste do trecho teve perda sedimentar $(-0,05$ a $-0,5 \mathrm{~m})$.

Entre os meses de Julho e Agosto (Fig.60), o trecho apresentou ganho sedimentar, com variação entre $1,2 \mathrm{~m}$ e $-0,9 \mathrm{~m}$. A linha d'água obteve as menores variações entre $(-0,9$ a $-0,4)$. O centro do trecho variou entre $0,4 \mathrm{~m}$ a $1,2 \mathrm{~m}$ e o restante entre $0 \mathrm{~m}$ e $0,2 \mathrm{~m}$.

O perfil do período total estudado, entre o primeiro dia de levantamento no mês de Junho e o último dia de levantamento no mês de Agosto (Fig.61), apresentou variação negativa para a Praia da Sununga $(0,6 \mathrm{~m}$ e $-1,4 \mathrm{~m})$. A área a oeste apresentou uma tendência deposicional na linha d'água e no limite superior, entre $0,6 \mathrm{~m}$ e $-0,1 \mathrm{~m}$, e o restante do limite superior manteve-se estável. Do centro do trecho para a área a leste a tendência foi erosiva em sentido crescente, sugerindo perda de sedimento $(-0,2 \mathrm{~m}$ a - 
$1,4 \mathrm{~m})$, com a presença de dois bancos migrando para a área oeste, o que confirma a dinâmica de rotação praial já descrita anteriormente por Martins (2006).

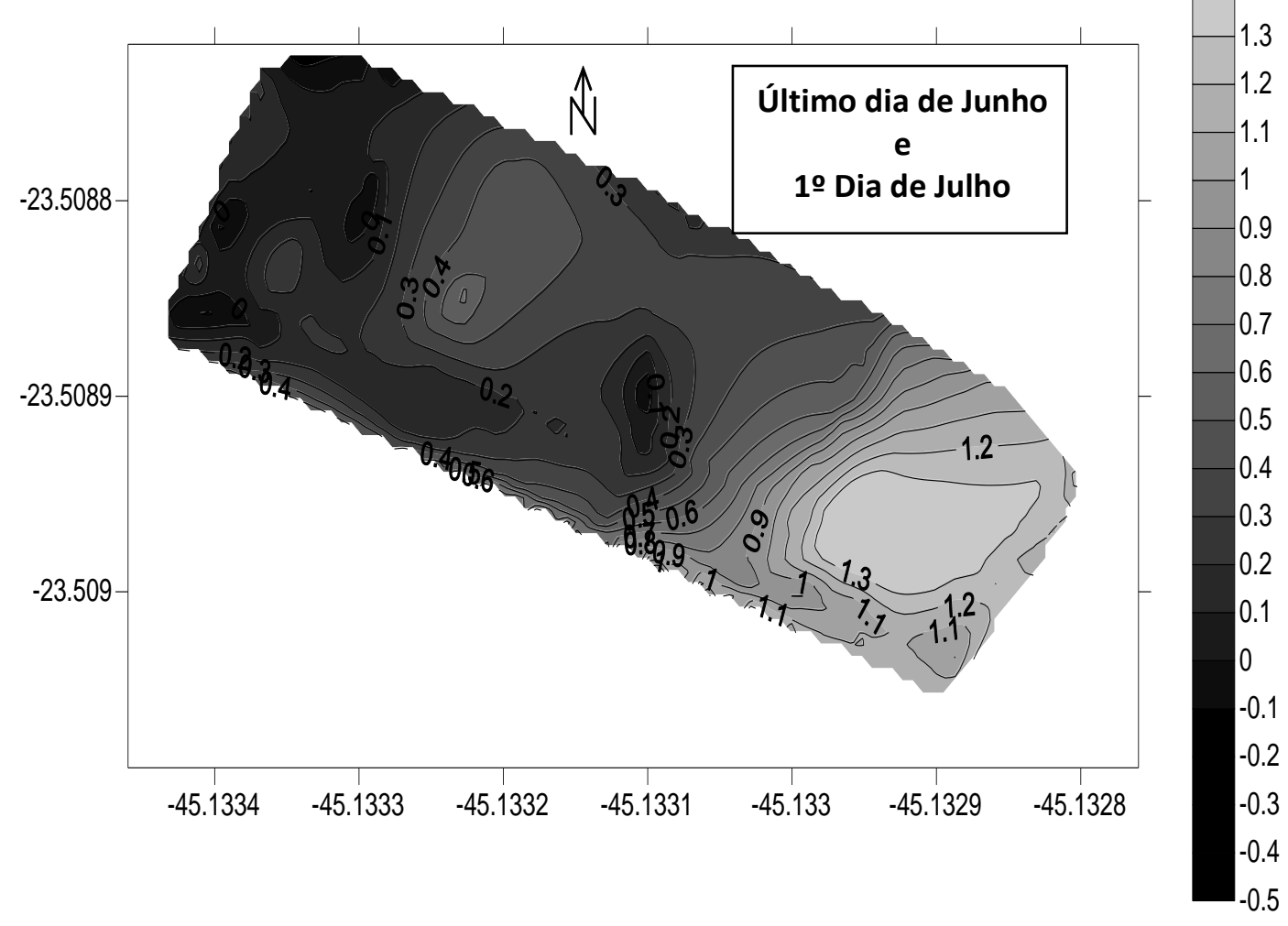

Figura 59 Gráfico de variação topográfica entre o último dia de Junho e o primeiro dia de Julho de 2012 para a praia da Sununga. 


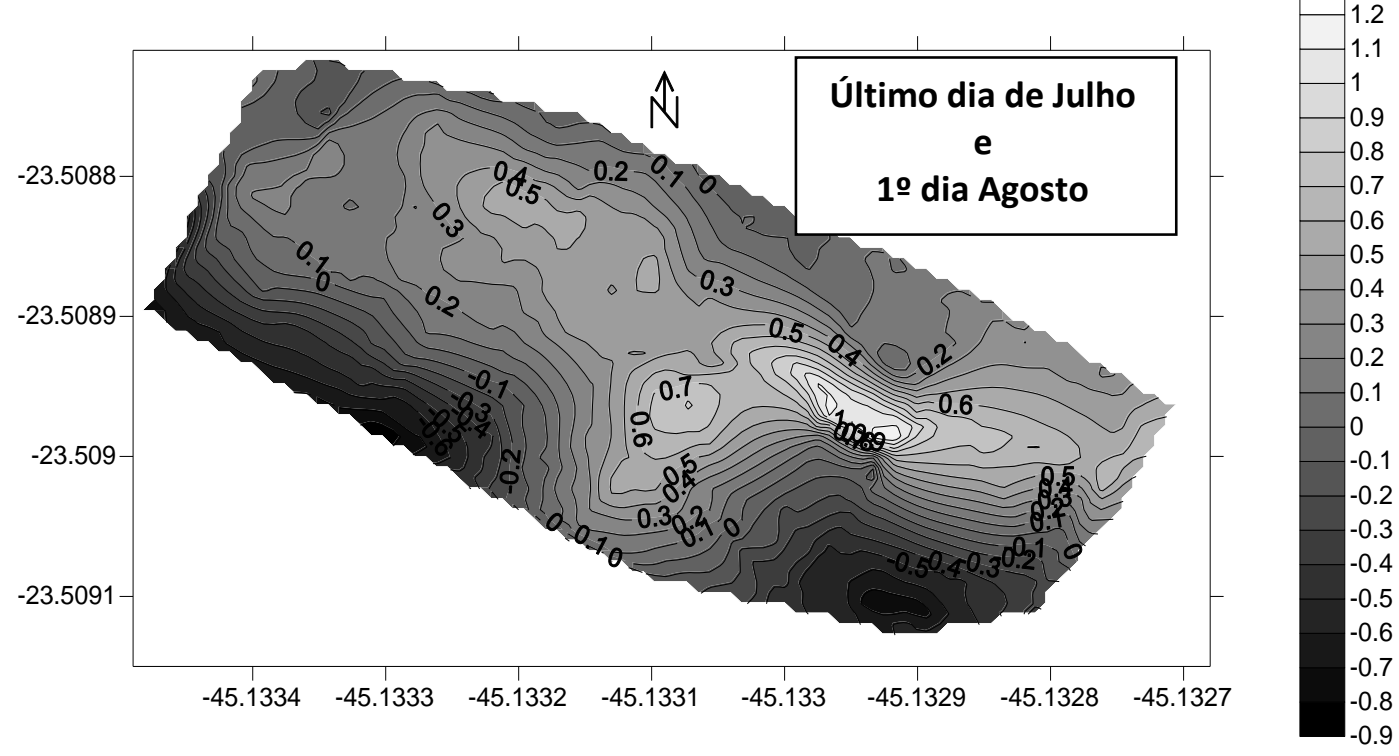

Figura 60 Gráfico de variação topográfica entre os último dia de Julho e o primeiro dia de Agosto de 2012 para a praia da Sununga.

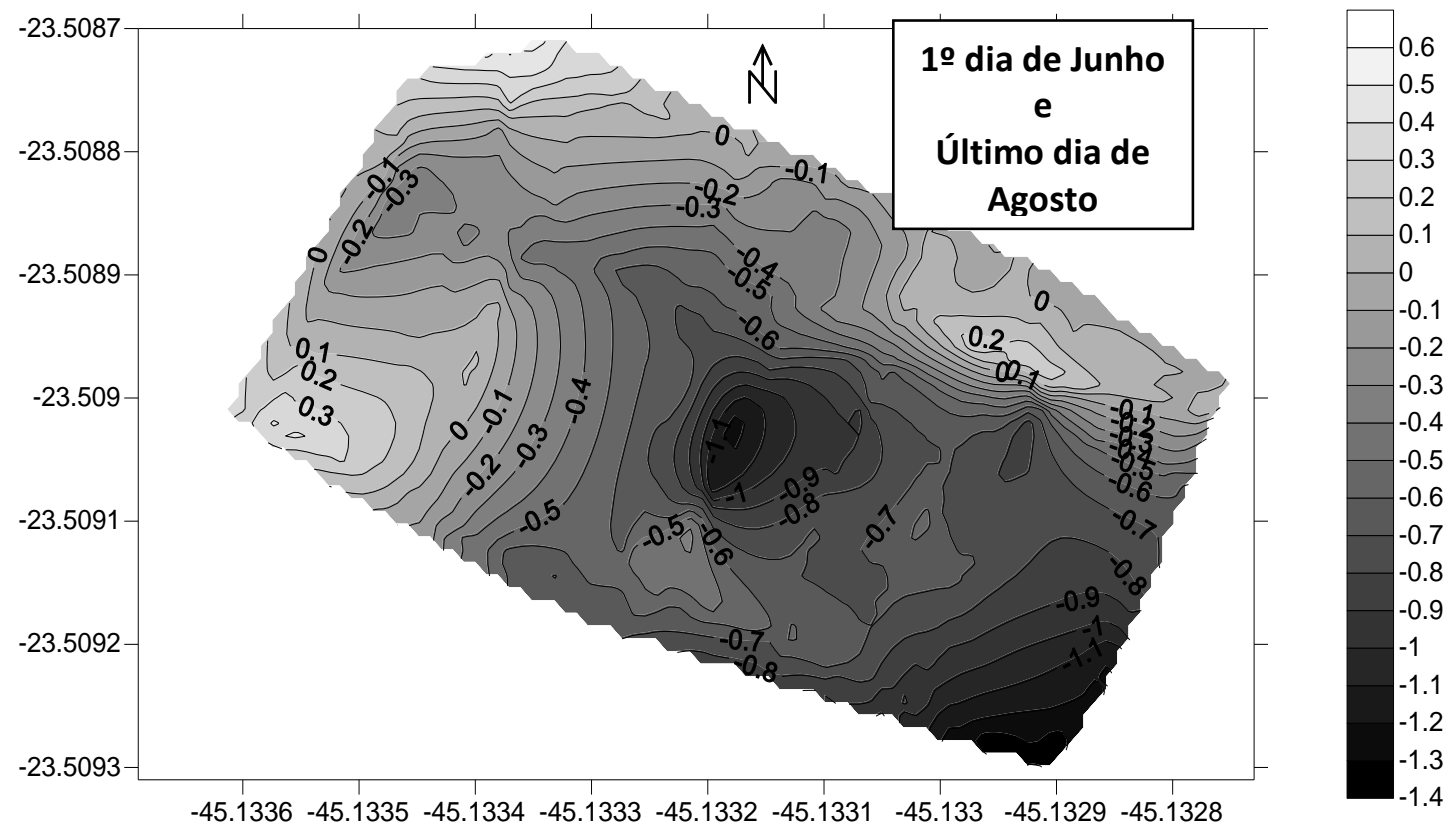

Figura 61 Gráfico de variação topográfica entre o primeiro dia de Junho e o último dia de Agosto de 2012 para a praia da Sununga. 


\subsection{Granulometria e Teor de Carbonato de Cálcio $\left(\mathrm{CaCO}_{3}\right)$}

Na praia do Lázaro, para os três pontos amostrados verificou-se ao longo do período estudado resultados de diâmetro médio do grão onde predominaram as areias muito finas (Fig 62), correspondendo a amostras bem selecionadas à muito bem selecionadas (Fig 63) em sua maioria, o que sugere uma única fonte.

A porcentagem de Carbonato de Cálcio é relativamente baixa comparada aos valores determinados na praia da Sununga não ultrapassando 7\%, sendo representativo de uma pequena influencia biodetrítica no trecho amostrado (fig 64).

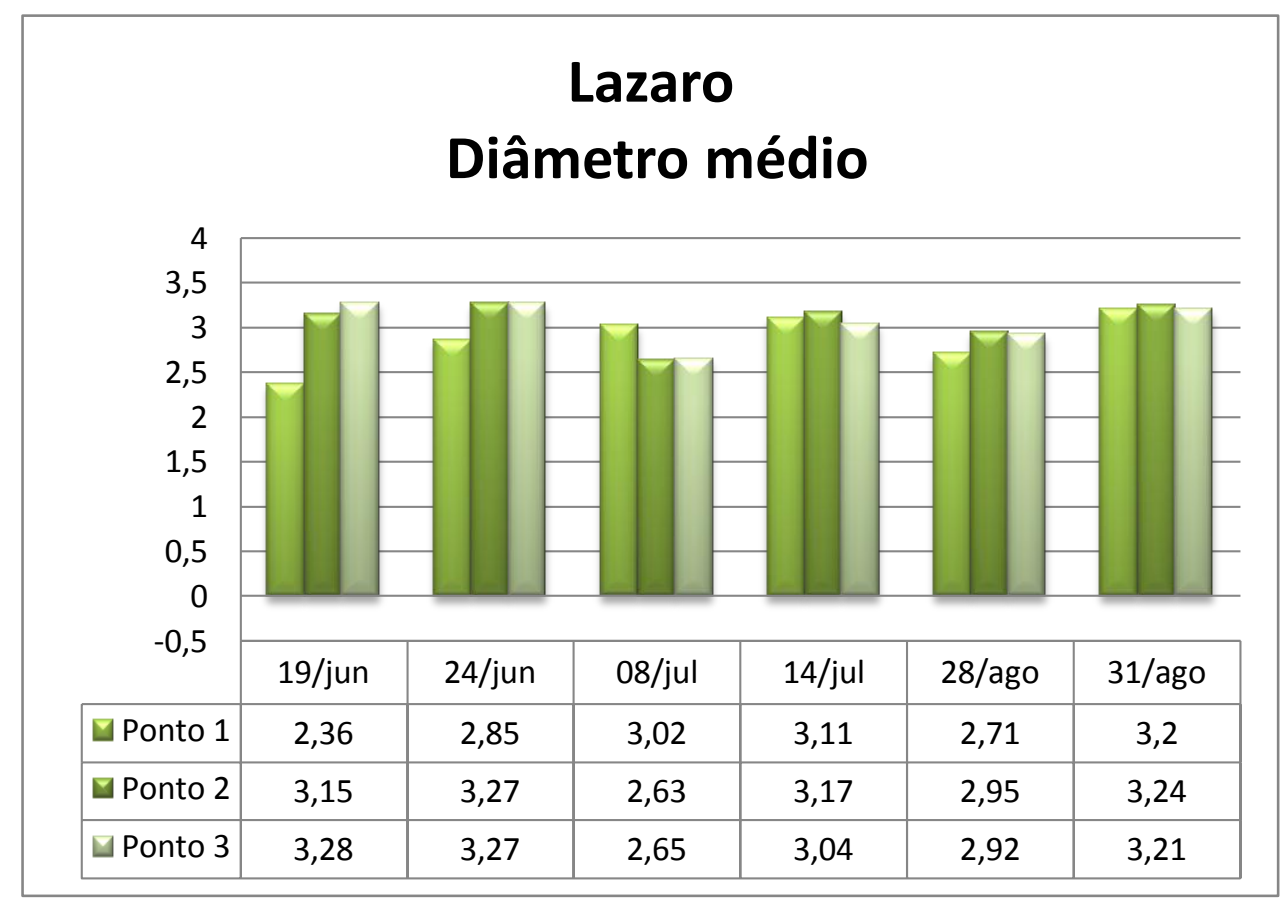

Figura 62 Gráfico de Diâmetro médio do sedimento para a Praia da Lázaro em Ubatuba -SP. 


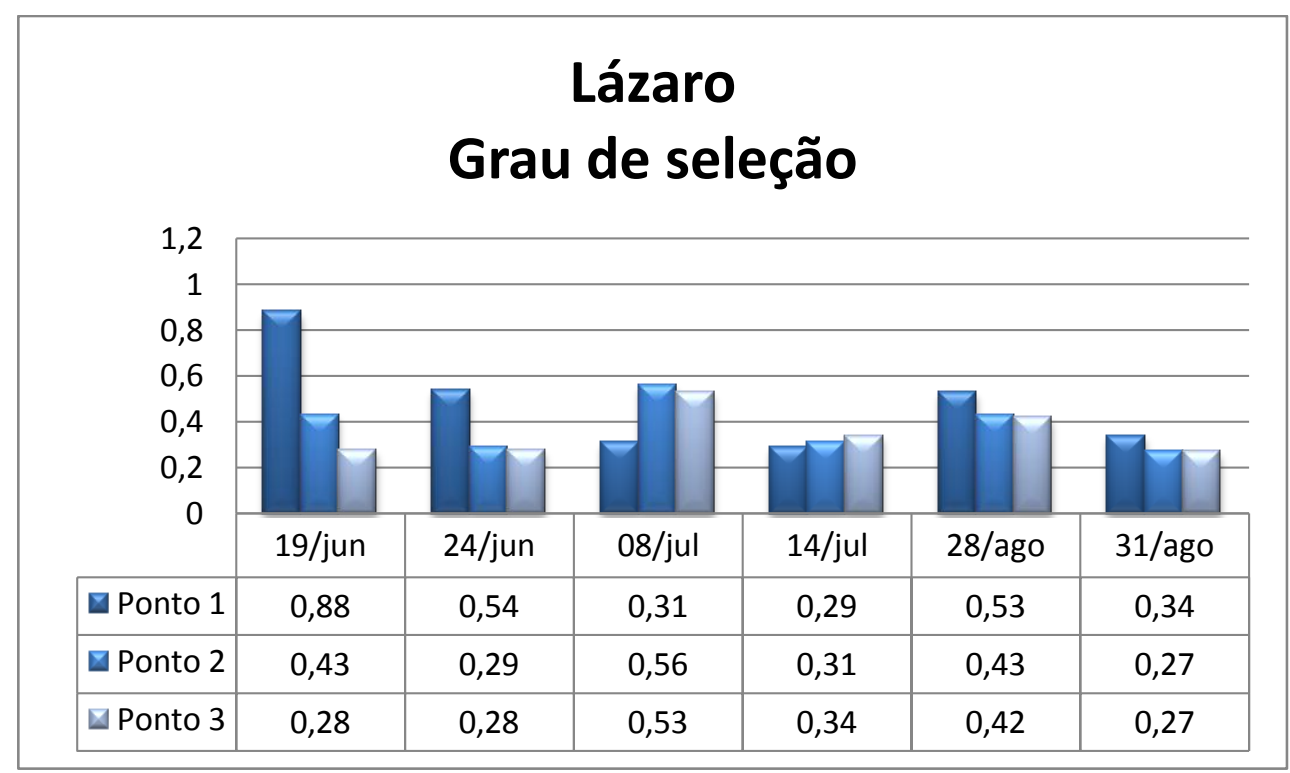

Figura 63 Gráfico de Diâmetro médio do sedimento para a Praia do Lázaro em Ubatuba -SP.

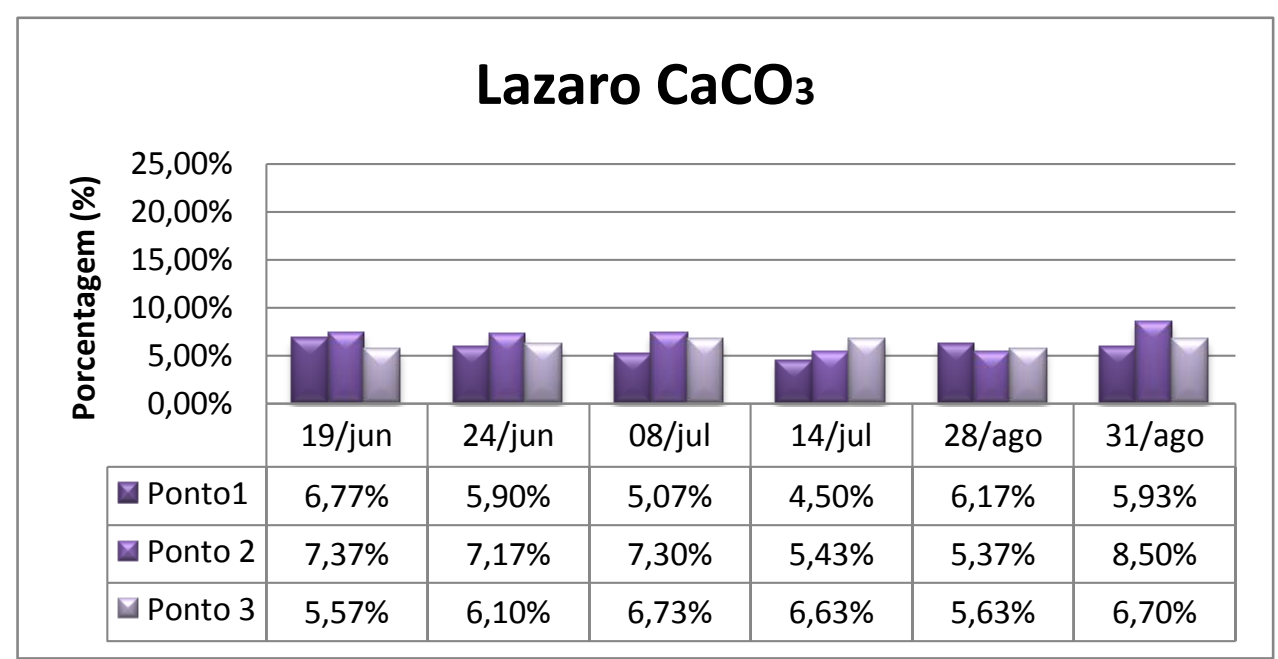

Figura 64 Gráfico de porcentagem de carbonato de cálcio do sedimento para a Praia do Lázaro em Ubatuba -SP.

Na praia da Domingas Dias, para os três pontos amostrados verificou-se ao longo do período estudado resultados de diâmetro médio do grão onde predominaram areias muito finas no Ponto 1 durante o mês de Junho. Para os meses de Julho e Agosto a predominância de areia média em situações de pré-frontal e fina na fase do pós- 
frontal. Para o Ponto 2 e Ponto 3 a predominância de areia fina e muito fina com alguns pontos de areia média. (Fig 65).

O gráfico da figura 66 apresenta uma influência significativa de Carbonato de Cálcio em ambos os pontos variando entre $10 \%$ e $20 \%$. Em relação ao grau de seleção, as amostras mostraram-se moderadamente selecionadas (Fig 67) confirmando a mesma hipótese sugerida para a praia da Sununga.

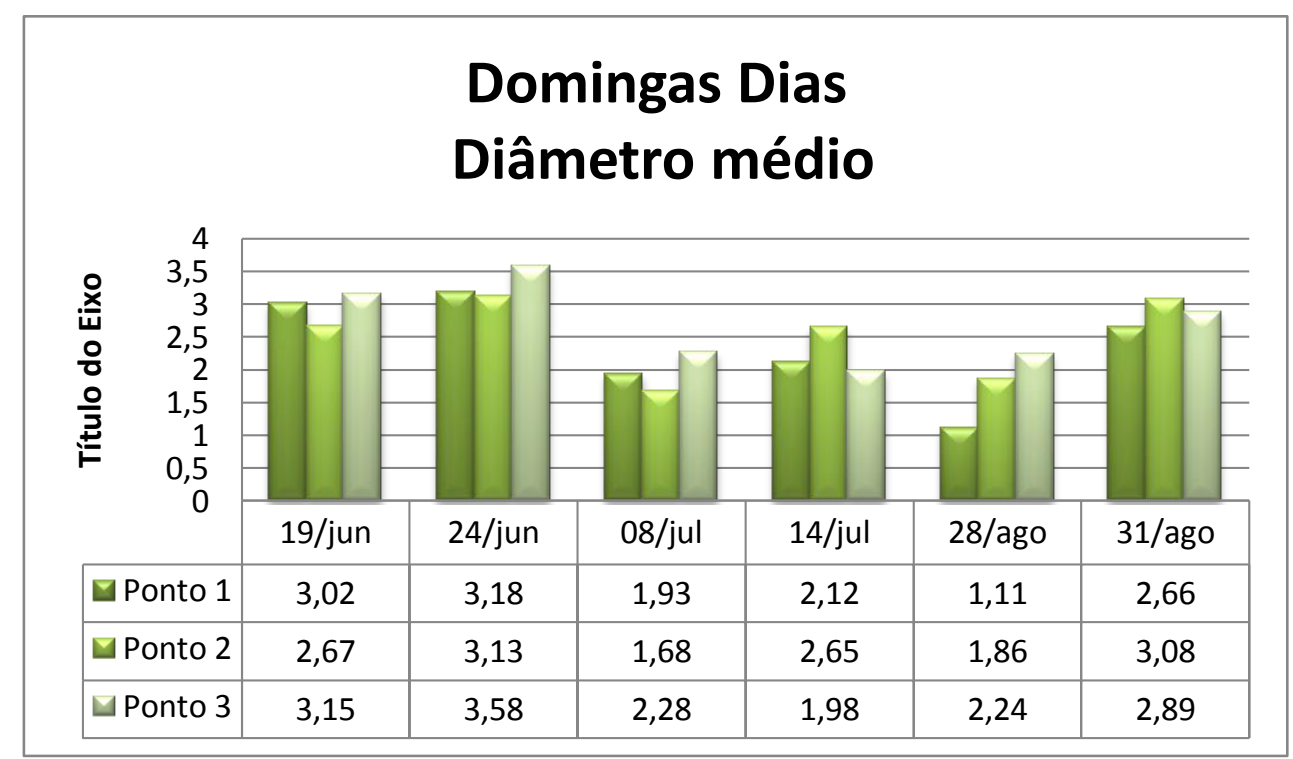

Figura 65 Gráfico de Diâmetro médio do sedimento para a Praia da Domingas em Ubatuba -SP. 


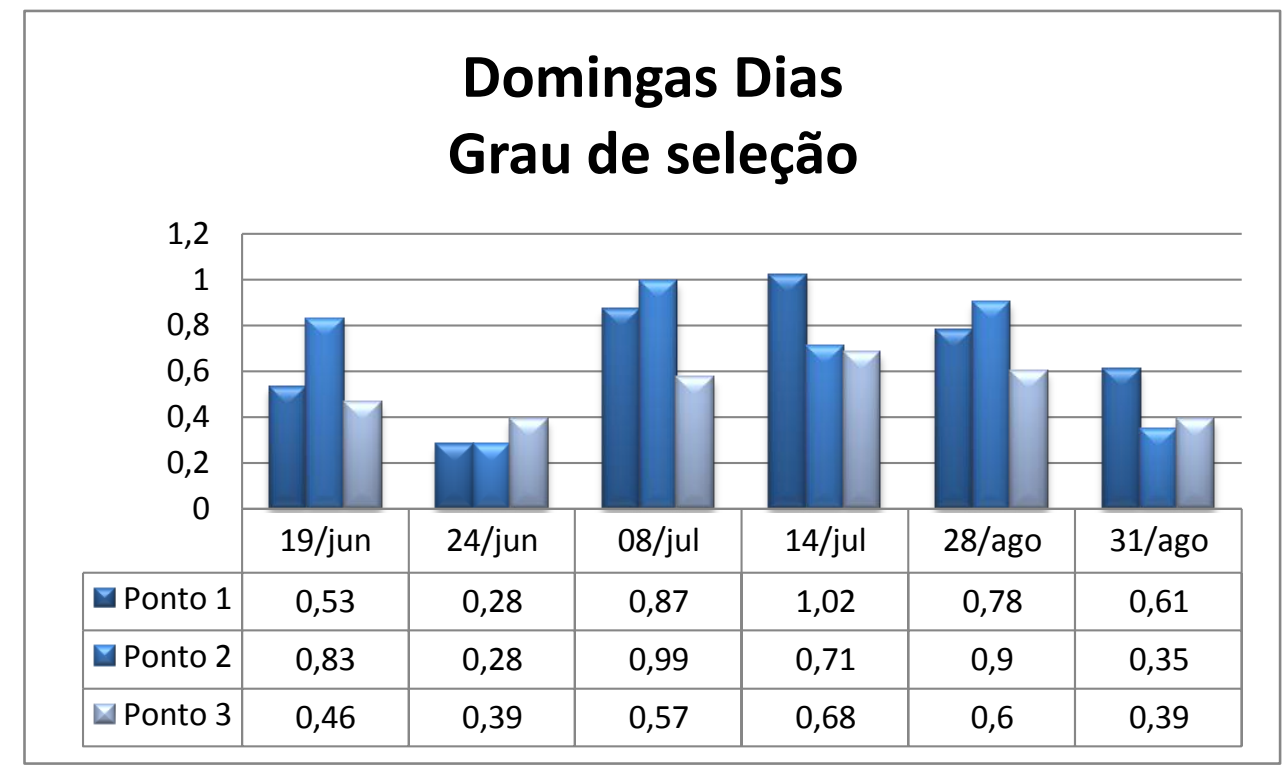

Figura 66 Gráfico do grau de seleção do sedimento para a Praia da Domingas Dias em Ubatuba -SP

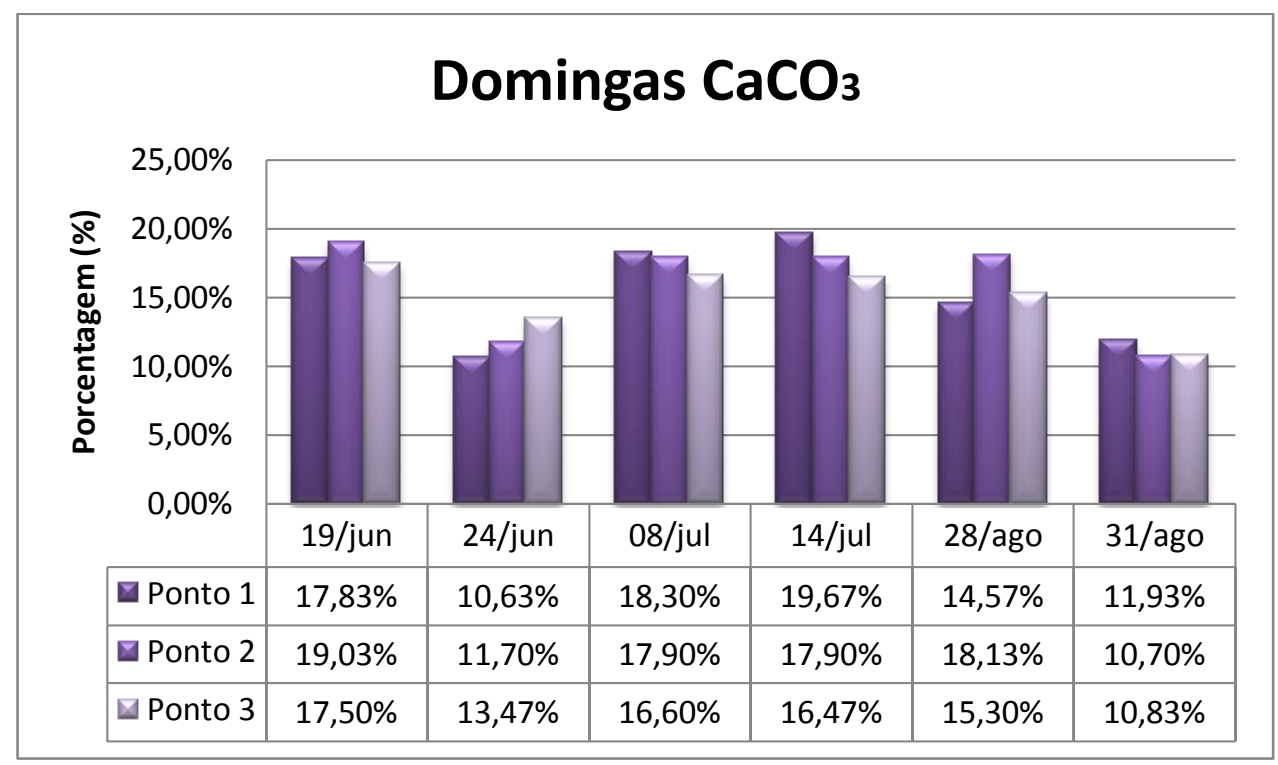

Figura 67 Gráfico de porcentagem de carbonato de cálcio no sedimento da Praia da Domingas Dias em Ubatuba -SP. 
Na praia da Sununga, para os três pontos amostrados verificou-se ao longo do período estudado, valores de diâmetro médio do grão onde predominou areia média para o Ponto 1, com exceção do mês de Julho, onde foi encontrado areia grossa. Para o Ponto 2, a predominância foi alternando durante as datas amostradas entre areia grossa e média, sendo que nos períodos de pré- frontal a predominância foi de areia grossa e no período de pós-frontal predomínio de areia média. Para o Ponto 3 a predominância foi de areia grossa em praticamente todas as datas amostradas (Fig 68).

A porcentagem de carbonato encontrada foi significante em todos os pontos, sendo maiores no Ponto 1 (Fig. 69), permitindo confirmar que é uma praia com uma forte influência biodetrítica. Os valores encontrados variaram entre 8,27\% e 23,33\%.

As amostras foram consideradas moderadamente selecionadas para ambos os pontos, o que sugere que o processo de ganho sedimentar é proveniente de duas concentrações de sedimento (fontes) distintos, apresentando uma variação na granulometria da praia, existindo parte considerável de sedimento diferente do predominante. O ponto 3 apresentou uma tendência à bem selecionado (Fig. 70). 


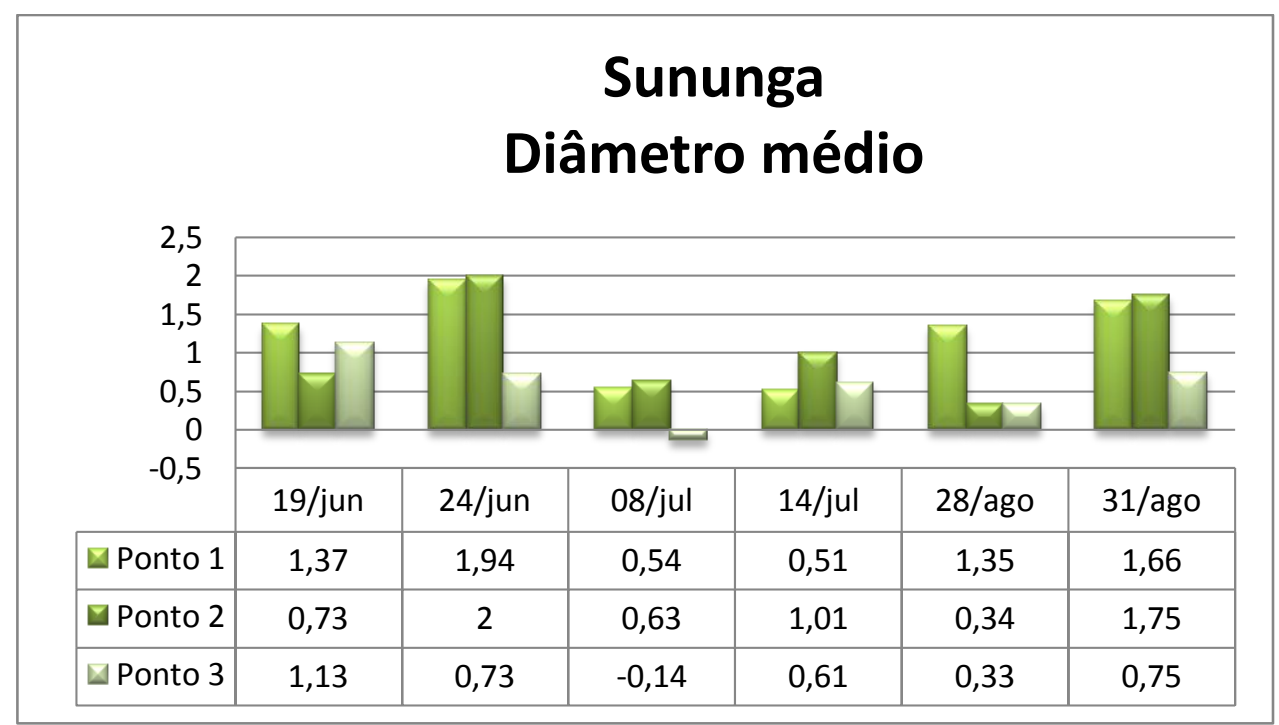

Figura 68 Gráfico de Diâmetro médio do sedimento para a Praia da Sununga em Ubatuba -SP.

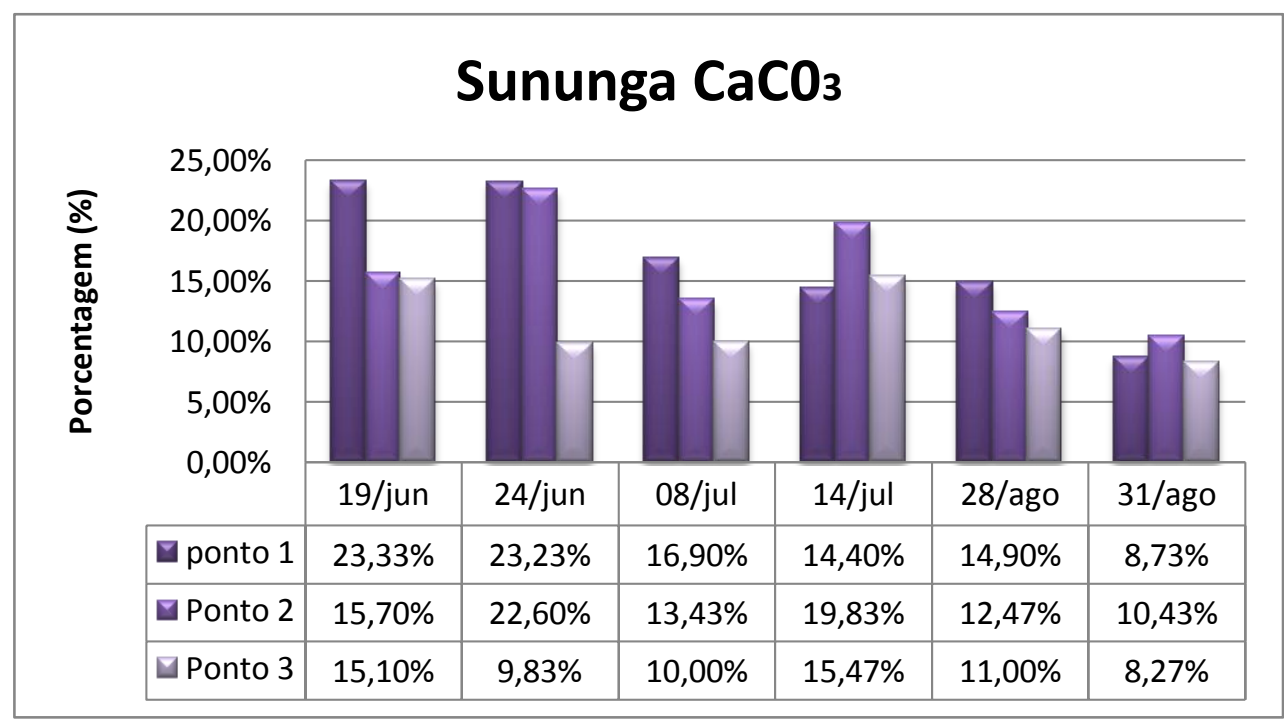

Figura 69 Gráfico de porcentagem de carbonato de cálcio no sedimento para a Praia da Sununga em Ubatuba -SP. 


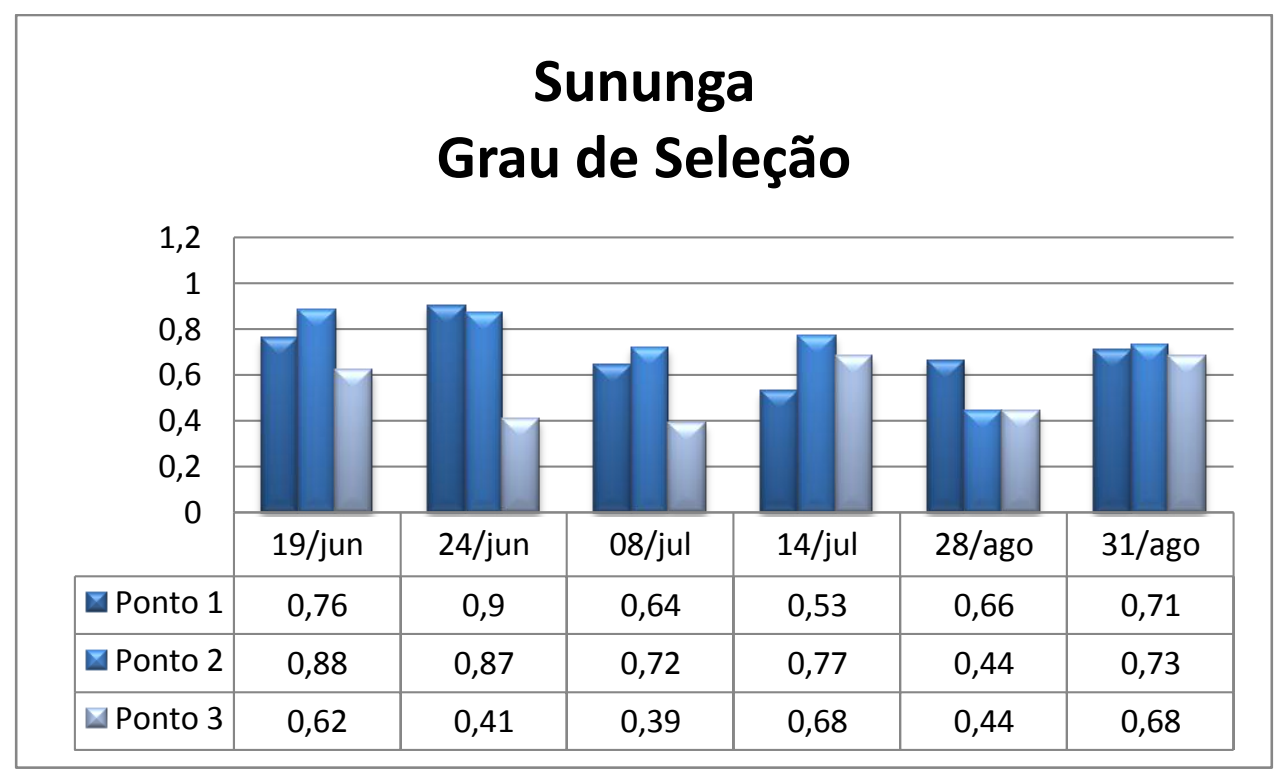

Figura 70 Gráfico de Grau de seleção do sedimento para a Praia da Sununga em Ubatuba -SP. 


\section{Discussão}

O estudo comparativo entre o comportamento de três segmentos praiais localizados na Enseada da Fortaleza, Ubatuba, SP, foi realizado em ano de El Niño, processo que tem como característica a geração de um comportamento anômalo para os sistemas atmosféricos, caracterizados pela diminuição da ocorrência de frentes frias na costa Brasileira (INPE,2012). No Brasil, esse fenômeno ocasiona alterações atmosféricas de diferente natureza e intensidade em diferentes regiões do país. Dentre estes comportamentos anômalos pode ser destacado o aumento significativo das precipitações e permanência dos sistemas frontais sobre a região Sul e, em contrapartida, sua menor incidência sobre a região sudeste, permitindo que prevaleça condição de tempo bom durante o inverno (MARTINS,2000).

Como consequência desse episódio climático foi observado no período do estudo, como padrão geral, um inverno com pouca variação morfodinâmica, com características deposicionais e de estabilidade morfológica das praias estudadas. Em algumas ocasiões foram observados eventos erosivos associados a sistemas frontais leves, com baixas perdas volumétricas, nas faces arenosas das praias da Enseada da Fortaleza.

Durante o período estudado ocorreu a passagem de três sistemas frontais, sendo dois deles no mês de Julho. Na campanha do mês de Agosto, ocorreu a ação do terceiro sistema frontal que rapidamente perdeu força e não conseguiu se estabelecer na área de estudo.

Durante o mês de Julho foi possível observar um empilhamento de água junto à costa (maré meteorológica), com seu pico durante um ciclo de maré de sizígia que se manteve durante o ciclo de quadratura seguinte. A maré meteorológica refletiu-se em campo pelo avanço da linha d'água, em todos os segmentos praiais estudados. 
Para o Sul do Brasil estão descritos quatro padrões sinóticos geradores de eventos extremos de tempestades. Esses padrões são definidos como Ciclogênese na costa sul da Argentina com um deslocamento para o leste e uma trajetória entre $47,5^{\circ} \mathrm{S}$ e 57, $5^{\circ} \mathrm{S}$; Ciclogênese na costa sul do Uruguai com um deslocamento para o leste e uma trajetória entre $28^{\circ} \mathrm{S}$ e $43^{\circ} \mathrm{S}$; Ciclogênese na costa sul do Uruguai com um deslocamento para o sudeste e uma trajetória entre $32^{\circ} \mathrm{S}$ e $57,5^{\circ} \mathrm{S}$; Centro de alta pressão (anticiclone), gerando vento e ondas de leste.

Para a região sudeste do Brasil, essas frentes tem sua caracterização definida pela sua intensidade, e não pela área do centro de geração do evento, identificadas pela pressão do centro gerador de baixa pressão.

As simulações realizadas pelo Sistema de Modelagem Costeira (SMC), mostraram o nível de exposição à entrada de ondas de diferentes direções de incidência em cada praia. Como já descrito anteriormente por Martins (2006), a Praia da Sununga com sua face praial voltada para S-SSW é a praia mais exposta as ondas dos quadrantes a Sul, e também a única dentre as três que sofre influência direta das ondas incidentes de leste. A Praia da Domingas Dias com sua face praial orientada para S-SSW é parcialmente exposta as ondas do quadrante sul, principalmente em seu setor localizado mais a oeste. A Praia do Lázaro é relativamente abrigada as incidências das ondas do quadrante sul, com seu setor oeste correspondendo ao segmento mais exposto a essa ondulação, pois sua configuração em curva de seu arco praial voltado para S-SSW, esta orientada para NE.

A análise temporal executada evidenciou que as praias se comportaram de maneiras distintas, sendo que a praia do Lázaro, abrigada aos sistemas incidentes de ondas dos quadrantes a S/SE, não respondeu diretamente, de forma mais efetiva, a 
passagem dos sistemas frontais. Durante esse evento, a Domingas Dias, semi exposta, ao mesmo padrão de incidência, perdia sedimento principalmente no seu segmento praial localizado a oeste, enquanto a Praia da Sununga, sofreu rotação no sentido horário de oeste para leste sob influência dos sistemas frontais.

A praia do Lázaro possui características morfológicas e sedimentares de praia dissipativa, sendo composta por areias de características texturais de fina a muito fina e bem selecionada, sugerindo uma única fonte de sedimento e/ou um processo de retrabalhamento prolongado. $\mathrm{O}$ sedimento apresentou valores insignificantes de carbonato de cálcio.

Para a praia do Lázaro o sistema frontal mais energético que se estabeleceu na região durante o mês de junho, causou uma pequena retirada de sedimento e as cúspides praias ficaram mais ''aparentes"', destacadas no relevo.

Essa praia é a mais abrigada das ondas do quadrante sul e consequentemente com pouca influência direta, mais pronunciada, dos sistemas mais energéticos. No período pós-frontal o perfil da face praial do Lázaro se recuperou, sendo que a parte mais a oeste da face praial, que apresentou as principais perdas sedimentares, tornou-se mais estável as variações verticais durante esse período.

O sistema de baixa energia que se estabeleceu sobre a área no mês de julho, não propiciou alterações significativas na morfologia da praia do Lázaro, ocorrendo pequenos acréscimos sedimentares no rumo a leste da face praial, tanto no período préfrontal, como durante o período de ação do sistema frontal.

Durante o mês de agosto, no qual não ocorreu passagem de sistemas frontal, a praia do Lázaro apresentou perda de sedimento. Tal perda representa um momento isolado, de apenas dois dias amostrados. Essa perda em uma larga escala de tempo, não 
corresponde a uma perda significativamente grande, como a ocorrida em períodos de sistema frontal, e sim a variações topográficas normais ocorridas durante os períodos de predomínio de incidências de ondas vinculadas aos sistemas climáticos denominados como "tempo bom".

As maiores variações verticais ocorreram na parte oeste do arco praial, muito provavelmente devido à influência de um canal fluvial. Esse canal originário da Serra do Mar adquire competência de transporte com o aumento da pluviosidade local, e consequentemente do aumento do seu fluxo de vazão. Durante esse mês foram medidos cerca de $500 \mathrm{~mm}$ de chuva.

As cúspides praiais da praia do Lázaro apresentaram em todos os perfis estudados uma maior variação, alternando perdas e ganhos verticais, associadas respectivamente a situações construtivas em condição de "tempo bom" e a situações destrutivas em condições de tempestade. Este comportamento padrão foi descrito por Masselink e Pattiaratchi (1998), que sintetizaram o comportamento evolutivo das cúspides com o padrão de circulação determinado pelo espraiamento, através dos mecanismos de "'uprush" e "backwash".

Entre o primeiro dia do mês de Junho e o último dia do mês de Agosto, o levantamento topográfico da face praial apresentou uma variação total negativa, comportamento esperado para o litoral norte paulista durante o período do inverno, onde a ação de sistemas de ondas incidentes de maior energia vinculadas aos frontais é mais pronunciada

A variação volumétrica total foi de $-68,65 \mathrm{~m}^{3}$, valor pouco significativo comparativamente as outras praias estudadas, o que permite comprovar que por ser um arco praial mais abrigado, com baixa influência de ondas do quadrante Sul e sudeste, 
com características mais dissipativas, tornam essa praia mais estável espacialmente ao longo do tempo, com menores variações topográficas de sua face praial e pouco influenciada pelos eventos meteorológicos frontais de baixa intensidade.

O mês que apresentou os maiores valores de perda sedimentar foi o de Agosto, período no qual não ocorreu a ação de eventos frontais.

Carter e Balsillie (1983) observaram que praias com tendência dissipativas são mais capazes de dissipar mais eficientemente a energia das ondas durante tempestades do que praias intermediárias ou refletivas, devido à presença de bancos de areia que criam obstáculos a incidência direta das ondas sobre o prisma praial. Embora a praia do Lázaro seja abrigada a ondulação do quadrante sul, esse fator também pode influenciar e explicar sua pequena variação morfológica durante a passagem de sistemas frontais mais intensos.

O diâmetro médio dos sedimentos da face praial da Praia da Domingas Dias é de areia fina com seleção moderada. Sedimentos arenosos finos não são comumente encontrados em praias com características de praias refletivas a intermediarias.

Porém, praias de energia alta a moderada também podem ser compostas por areia fina, sendo que nesse caso esta relação indicaria que o sedimento pode corresponder a um material pré existente e não estar diretamente relacionado as características de inter-relação entre praias refletivas e os sedimentos mais grossos (SHORT et al. 1979, WRIGHT E SHORT, 1984, SHORT, 1999; KLEIN et al, 1999;. KLEIN E MENEZES, 2001). As porcentagens de carbonato de cálcio indicam a o predomínio de um sedimento biodetrítico.

Para o mês de junho, durante a passagem do sistema frontal de maior energia, na praia Domingas Dias, que é semi exposta às ondas do quadrante sul, ocorreu perda 
sedimentar significativa na maior parte do arco praial. Após a passagem do sistema, período pós-frontal, foi observado um acrescimento vertical de material sedimentar no trecho mais a leste da face praial.

Durante o mês de julho, com a ação de um sistema frontal de baixa energia, a praia de Domingas Dias apresentou perda de sedimentos durante o período pré-frontal nas áreas mais a oeste do arco praial. No período após a ação mais intensa da frente, pós- frontal, o perfil se restabeleceu parcialmente, com continuada perda na sua área mais a oeste e ganho à leste com relação ao perfil inicial de referência.

Durante o mês de agosto, quando não ocorreu passagem de sistema frontal, a praia de Domingas Dias apresentou ganho sedimentar com uma pequena perda sedimentar nas cúspides praiais do lado oeste para o centro do trecho estudado.

A praia da Domingas Dias, ao longo de todo o período de levantamento, apresentou perda sedimentar, com as maiores variações no setor mais a leste da área. Durante o mês de Julho o arco praial apresentou com uma maior variabilidade na área localizada a oeste e menor a leste do arco praial.

Em todas as campanhas foram observadas a presença de cúspides praiais com significativas variações de posição espacial sobre o prisma praial.

Durante o mês de Agosto, quando nenhum sistema frontal conseguiu se estabelecer sobre a área, a praia da Domingas Dias embora tenha apresentado pequena perda sedimentar, mostrou maior estabilidade. Os maiores ganhos sedimentares foram observados nas áreas das cúspides praiais e perda sedimentar estabelecidas no limite superior da face praial estudada. 
Durante o mês de Julho, onde ocorreu a ação mais efetivas dos sistemas frontais, a praia conseguiu se restabelecer apresentando um acréscimo sedimentar após o final da campanha de campo.

$\mathrm{Na}$ análise comparativa entre os meses de Junho e Julho, o perfil se recuperou, diferentemente do intervalo entre Julho e Agosto, que manteve maiores ganhos na parte oeste, e menores leste, área que não apresenta influência mais direta das ondas do quadrante sul.

O prisma praial da praia ao longo de todo o período estudado, entre o primeiro dia de Levantamento no mês de Junho e o último dia de levantamento no mês de Agosto, mostrou um padrão erosivo com um volume total de variação de $-388,26 \mathrm{~m}^{3}$.

Tais análises possibilitaram classificar a Praia de Domingas Dias como semi exposta as ondas do quadrante sul com características refletivas, que impedem a dissipação das ondas fazendo com que elas cheguem com mais energia na arrebentação e no espraiamento sobre a face praial.

O diâmetro médio dos sedimentos da face praial da praia da Sununga é de médio a grosso, com alta porcentagem de carbonato de cálcio, indicando corresponder a um sedimento predominantemente biodetrítico, comum em praias refletivas com atividade biológica como é o caso da Sununga. Consequentemente por possuir amostras de sedimentos moderadamente selecionada em todos os pontos a praia da Sununga não possui homogeneidade em seu diâmetro médio. A praia da Sununga possui um alto retrabalhamento dos grãos, com mistura de sedimentos mais finos e mais grossos. Os finos se misturam mais intensamente aos sedimentos mais grossos em diferentes ritmos, ocasionando mistura de sedimentos em proporções diferentes ao longo de todo o arco praial no tempo. 
As perdas e ganhos verticais de sedimento nas zonas de espraiamento e surfe ocorrem na forma de migração longitudinal de bancos, e não diretamente associados apenas a passagem de sistemas frontais ou de tempo bom, como observado nas outras praias. Por ser uma praia de bolso, sem troca de sedimentos com as outras praias da mesma enseada, sem contribuição atual de outros segmentos costeiro, a praia da Sununga se apresenta igualmente ao que se foi encontrado por Miot da Silva et al. (2000), que estudando o padrão de distribuição de sedimentos nas praias de Santa Catarina, também não identificou processos de troca de sedimentos entre as praias contíguas.

Durante o mês de Junho, quando da passagem do sistema mais energético sobre o litoral norte paulista, a praia da Sununga apresentou migração de seus bancos para leste, com consequente perda de sedimentos à oeste do arco praial. Após a passagem da frente, no período pós-frontal esse sentido de deslocamento se inverteu ocorrendo perda a leste e deposição nos setores a oeste da praia.

No mês de Julho sob a ação de um sistema menos energético, o perfil se comportou da mesma maneira, com migração do banco de oeste para leste. Porém, na fase de ação do pós-frontal a praia apresentou ganho sedimentar em todo o trecho e não apenas no setor a oeste da face praial.

Durante o mês de agosto, não ocorreu passagem de sistemas frontais na região. Entretanto, a praia apresentou perda sedimentar migratória de leste para oeste, sentido oposto do observado com predominância de ondas do quadrante sul, o que sugere que as ondas do quadrante leste e nordeste, são as responsáveis pelo restabelecimento do setor oeste, auxiliando no processo de rotação praial conforme descrito em Martins (2006). 
Ao longo do período estudado foi possível acompanhar a migração de dois bancos para setores à leste do arco praial, áreas que sofrem erosão sob a influência das ondas do quadrante leste, predominantes durante os períodos de "tempo bom". A ausência de sistemas frontais e o predomínio de condições de 'tempo bom" permitem o restabelecimento da praia em suas condições de maior acreção.

Segundo Benavent et. al. (2002) a possibilidade das praias se recuperarem após a passagem de uma tempestade depende da disponibilidade de sedimento existentes na recuperação das características morfodinâmicas de "tempo bom" como também de adaptar os perfis a novos eventos de condições de alta energia de ondas. Foram este conjunto de condições que estiveram presentes durante o mês de Agosto para o arco praial da praia da Sununga.

Como pode ser observado nas praias da enseada da Fortaleza, as relações entre diâmetros médios dos sedimentos e declividade das faces praiais guardam relação direta com as descrições clássicas da literatura científica.

$\mathrm{Na}$ praia do Lázaro o tamanho dos sedimentos e a incidência das ondas controlam a forma em planta da praia e sua dinâmica. Normalmente, o predomínio de areia fina produz uma menor inclinação na face praial e uma maior zona de surfe, pois este é um sedimento com maior potencial móvel. Praias constituídas de areia média e areia grossa, como observado na praia da Sununga, possuem um declive mais acentuado e uma zona de surfe mais estreita. Praias refletivas geralmente são compostas por areias grossas, enquanto praias dissipativas são compostas por sedimentos arenosos mais finos e praias intermediárias por areias médias (KLEIN E MENEZES,2001).

No litoral sul e sudeste do Brasil os sistemas de ondas provenientes do quadrante a Sudeste e Sul tem grande influência sobre o perfil das praias, como descrito 
previamente por Klein e Menezes (2001). Consequentemente, o maior impacto das variações morfodinâmicas da praia e mobilidade do perfil, ocorre em direção ao setor predominante da deriva gerada pelos sistemas predominantes de ondas incidentes. Tal fato foi observado em todas as praias estudadas da Enseada da Fortaleza, apresentando variações verticais negativas (erosão) sempre no sentido de oeste para leste.

Tabela 4 Quadro síntese dos sistemas frontais correlacionados com as características de cada praia.

\begin{tabular}{|c|c|c|c|c|c|c|}
\hline & Praia & $\begin{array}{l}\text { Direção } \\
\text { geral face } \\
\text { praial }\end{array}$ & $\begin{array}{c}\text { № de } \\
\text { frentes no } \\
\text { período }\end{array}$ & $\begin{array}{c}\text { Dias } \\
\text { transcorridos } \\
\text { desde a } \\
\text { última frente }\end{array}$ & $\begin{array}{l}\text { Direção de } \\
\text { incidência } \\
\text { de ondas }\end{array}$ & $\begin{array}{l}\text { Granulometria } \\
\text { predominante }\end{array}$ \\
\hline \multirow{3}{*}{ Junho } & Lázaro & S-SSW & 1 & 13 & $\mathrm{E}$ & Muito fina \\
\hline & Domingas Dias & S-SSW & 1 & 13 & SE & Fina \\
\hline & Sununga & S-SSW & 1 & 13 & $\mathrm{~S}$ & Média \\
\hline \multirow{3}{*}{ Julho } & Lázaro & S-SSW & 2 & $18 / 5$ & $\mathrm{E}$ & Muito fina \\
\hline & Domingas Dias & S-SSW & 2 & $18 / 5$ & SE & Fina \\
\hline & sununga & S-SSW & 2 & $18 / 5$ & $\mathrm{~S}$ & Média \\
\hline \multirow{3}{*}{ Agosto } & Lázaro & S-SSW & 0 & 22 & $E$ & Muito fina \\
\hline & Domingas Dias & S-SSW & 0 & 22 & SE & Fina \\
\hline & Sununga & S-SSW & 0 & 22 & S & Média \\
\hline
\end{tabular}

Durante o evento frontal atuante durante o mês de junho a Praia do Lázaro, que é relativamente abrigada das ondulações do quadrante Sul, não sofreu alterações significantes. Neste período a Praia da Domingas Dias que é semi exposta as ondas incidentes durante a passagem dos sistema frontais, apresentou perda sedimentar vertical na maior parte do segmento praial. A praia da Sununga apresentou migração de seus bancos rumo a leste, com perda de volume de sedimentos (erosão) nos setores localizados a oeste do arco praial. Durante esse mês foram observados os maiores valores de remobilização de volume de sedimentos ao longo da praia.

Para o mês de agosto quando não foi observada a passagem de sistema frontal sobre o litoral norte paulista torna-se clara a influência das ondas do quadrante sul na 
remobilização sedimentar das praias expostas (Sununga) e semi expostas (Domingas Dias), e que a praia do Lázaro, abrigada as ondas desse mesmo quadrante, não responde morfologicamente de forma direta a passagem dos eventos atmosféricos mais energéticos. Por outro lado, ficou bem estabelecida a influência das ondas incidentes dos quadrantes a leste e nordeste (tempo bom e pós-frontal) na reconstrução dos perfis.

Foi observado que essas praias não possuem troca sedimentar entre elas e cada praia possui seu próprio estoque sedimentar em possíveis bancos arenosos submersos, possuindo características granulométricas distintas.

Na praia da Sununga, durante o período de levantamento foi observada uma grande variação topográfica do arco praial, predominando uma tendência geral de perda sedimentar. De maneira geral, o setor oeste apresentou predomínio erosivo, enquanto o setor oposto do arco praial (Leste) a tendência predominante foi deposicional.

Este comportamento reforça a percepção da existência de um processo de rotação praial conforme descrito por Martins (2006), quando considerados estas modificações morfológicas dentro de uma escala temporal curta, respondendo à alternância na direção de incidência das ondas de tempestades geradas com a passagem de ciclones tropicais sobre a região, e as ondas de "'tempo bom', com sua ação predominante, em tempo, ao longo do litoral norte paulista e com a passagem de ciclones tropicais sobre a região (SHORT, et.al., 2000; SHORT, 2000; KLEIN et.al.,2002, MARTINS, 2006).

Short et al. (2000) identificaram rotação praial numa praia intermediária em Sydney (Narraben beach), com ciclos de rotação variando de 3 a 8 anos. No caso da praia da Sununga esses processos podem ser diários e em ciclos atmosféricos, ou seja, 
entre o predomínio dos parâmetros oceanográficos presentes entre os períodos de pré e pós-frontal.

Segundo Martins (2006), na praia da Sununga, quando os ciclones extratropicais avançam sobre a área, as ondas passam a incidir a partir dos quadrantes sul e sudeste, e o material depositado no setor oeste é remobilizado e transportado na direção oposta. Em tempo bom, as ondas incidentes dos quadrantes leste e nordeste, são responsáveis pela erosão do setor leste e deposição a oeste.

Essa rotação foi observada em todos os períodos de levantamento de campo, com exceção do mês de Agosto, onde não foi executado levantamento sob a ação de eventos frontais (períodos de pré-frontal).

Para a Praia da Sununga, o acompanhamento da variabilidade dos perfis entre os meses amostrados indicaram a capacidade de restabelecimento dos níveis de acresção e perda sedimentar, mostrando a importância dos sistemas frontais no transporte longitudinal de sedimento na área e em seu processo de rotação praial, que permite a existência do restabelecimento da face praial vista não existir perda sedimentar entre o arco praial da Sununga e as áreas das praias contíguas.

Klein (2002) e Klein et.al. (2006) observaram que igualmente a mobilidade do perfil em curto prazo, os processos de rotação de praia podem diferir significativamente entre praias dissipativa, refletivas e intermediárias, e assim entre as praias com diferentes graus de curvatura e exposição às ondas incidentes. Neste trabalho, os processos de rotação de praia foram mais facilmente detectados em praias refletivas e expostas a incidência de sistemas de ondas geradas em eventos de alta energia como, por exemplo, a Praia de Taquaras/Taquerinhas, que possuem as mesmas características morfológicas que a Praia da Sununga. Neste caso, com a ausência de barras submersas, 
a energia das ondas colapsa diretamente sobre a inclinação da praia, levando a uma maior mobilidade do perfil e a remoção de grandes quantidades de sedimento na praia emersa. Como resultado, a ocorrência de ondas oblíquas sobre estes tipos de sistemas de praia provoca troca de sedimento entre as suas extremidades. O processo de Rotação de praia é influenciado diretamente por mudança na direção predominante de ondas incidentes, transportando o sedimento de leste para oeste quando ocorrem ondas do quadrante leste e de oeste para leste quando ocorrem ondas do quadrante sul.

No caso da praia de Domingas Dias, o período amostrado não permite comprovar a existência ou não de um processo de rotação, embora ela apresente características favoráveis a esse fenômeno, por ser uma praia de bolso, de característica morfológica intermediária e semi exposta a ação das perturbações atmosféricas de Sul. Entretanto, foi possível identificar que de maneira geral a sua porção a oeste, apresenta uma maior influência das ondas do quadrante sul, enquanto sua porção a leste, das ondas do quadrante a leste e nordeste .

Embora as praias estejam todas inseridas na Enseada da Fortaleza e possuam as mesmas características geológicas, oceanográficas e atmosféricas e que, cada praia tem seu arco praial orientado para S/SW de maneira distinta, diferentes graus de exposição (expostas, abrigadas), e que permite que as ondulações entrem na enseada de diferentes sentidos e intensidades e resultando, consequentemente, em padrões morfológicos distintos. 


\section{Conclusão}

A análise dos resultados permitiu caracterizar a variabilidade espaço temporal dos arcos praiais da enseada da Fortaleza como resultantes da interação de um conjunto de fenômenos de origem climática, geológica, oceanográfica e antrópica, possibilitando compreender a evolução morfológica desse segmento costeiro sob a ação da passagem de sistemas frontais.

As praias do Lázaro, Domingas Dias e Sununga, embora estejam inseridas na mesma enseada, e possuam as mesmas características geológicas, meteorológicas e oceanográficas, se comportam de maneiras distintas frente aos processos dinâmicos de ondas geradas nos sistemas frontais, e nos sistemas de "tempo bom”, devido ao nível de exposição a que ficam submetidos seus arcos praiais a incidência de ondas provenientes de distintas direções.

A praia do Lázaro, a mais abrigada, não tem sua dinâmica sedimentar diretamente alterada pela passagem dos sistemas frontais, enquanto o segmento praial semi-exposto, Domingas Dias, e a Sununga, completamente exposto a incidência direta das ondas provenientes dos quadrantes a sul, respondem diretamente em mecanismo tipo causa/efeito, a esses sistemas frontais. Esta exposição variável das praias de diferentes orientações de seus arcos praiais, geram transferências mais significativas de sedimentos entre a área emersa e submersa da praia, bem como sob o predomínio de incidências de ondas provenientes dos quadrantes a norte e leste propiciam o restabelecimento dos prismas das faces praiais em sua configuração mais agradada.

Considerando que todo o litoral norte de São Paulo recebe a incidência de ondas dos quadrantes a norte/leste e sul, que representam respectivamente as ondas mais frequentes e menos esbeltas, vinculadas ao genericamente denominado como "ondas de 
tempo bom”, e as mais energéticas associadas aos eventos climáticos extremos (frentes frias), observa-se que para a enseada da Fortaleza os arcos praiais sobre a qual incidem estes grupos de ondas, respondem diferentemente aos ângulos de incidência e a intensidade de liberação de energia na arrebentação.

As praias que possuem suas faces voltadas rumo aos quadrantes a sul, e não apresentam impedimento físico a incidência direta das ondas (Sununga - desabrigada), possuem suas porções localizadas mais a oeste do arco praial sujeitas a significativas alterações nos volumes de areia depositados sobre a face da praia, particularmente sob influência de ondas associadas as fases de pré-frontal e frontal. Sob a ação efetiva destes eventos a remobilização sedimentar é mais intensa quando comparado com a fase de predomínio do sistema pós-frontal.

Nesta etapa, quando passa a predominar a incidência de trem de ondas dos quadrantes norte/leste, que representam numericamente o maior período de atuação sobre o litoral paulista, porém de menor capacidade de remobilização sedimentar, se processa a inversão da direção predominante da deriva praial transferindo parte do material de volta para a superfície emersa e, significativo volume de sedimentos, para as porções mais a Oeste da praia. Nestas fases, pós-frontal e "tempo bom", foram observados os mais efetivos processos de reconstrução dos prismas praiais, mesmo nos segmentos costeiros abrigados (Lázaro) e semi abrigados (Domingas Dias).

Muito embora os levantamentos dos prismas praiais não tenham coberto o segmento correspondente a área submersa da praia (zonas de arrebentação e surfe), até o ponto de fechamento interno, os estudos sedimentológicos e a configuração espacial dos promontórios, indicam a "auto suficiência" das praias com relação ao seu estoque de sedimentos, não apresentando processos de transferência de sedimentos de fundo entre 
as praias contíguas (Sununga, Lázaro, Domingas Dias). Tal fato pode explicar o equilíbrio dinâmico e sedimentar observado, sem perda significativa de massa sedimentar para fora da área de dinâmica mais intensa dos segmentos praiais, possibilitando a recuperação do perfil praial, em curta escala de tempo, após os efeitos erosivos gerados pelas ondas de eventos climáticos extremos.

O acompanhamento espaço temporal das três praias da enseada da Fortaleza, todas com suas faces praiais voltadas rumo aos quadrantes a sul, sob as mesmas condicionantes de origem climática, geológica, oceanográfica e antrópica, evidenciaram que a intensidade dos processos de perda e recuperação sedimentar destas praias não dependem apenas do grau de proteção, ou exposição, destes ambientes a ação mais direta das ondas mais esbeltas, mais energéticas, mas também da possibilidade de remobilização de sedimentos dentro do próprio prisma praial.

A ausência de sistemas de drenagem mais competentes no aporte de novos sedimentos aos sistemas costeiros da enseada da Fortaleza, como igualmente ocorre para todas as praias localizadas nas diversas enseadas existentes no litoral norte paulista, corresponde a um fator limitante no tempo e na efetividade de recuperação dos perfis praias submetidos a efeitos erosivos naturais, tempestades, ou a ação antrópica de retirada de material granular das praias, ou mesmo a interrupção física da transferência sedimentar entre os extremos dos arcos praiais.

Desta forma, para o estabelecimento de programas de gerenciamento costeiro mais adequado ao padrão de dinâmica sedimentar das praias de enseada do litoral norte paulista, deve-se considerar como elementos de análise dentro do conceito de estabilidade de praias, não apenas considerações sobre o rumo para o qual está voltada a face de cada praia, do grau de proteção, natural ou não, destes segmentos costeiros em 
relação a direção principal dos quadrantes de incidência das ondas ("tempo bom" e tempestade), da variabilidade dos ângulos de incidência sobre o prisma praial, mas, principalmente, da possibilidade de retenção dentro do próprio segmento costeiro, do estoque de sedimentos remobilizados durante os eventos de tempestade, e da possibilidade de remobilização dos sedimentos não apenas entre as porções emersa e submersa do perfil, mas também da inexistência de elementos impeditivos a livre transferência de areias entre as áreas espacialmente opostas nas praias. 


\section{Referências}

AB'SABER, A. N. Contribuição à geomorfologia do litoral paulista. Revista Brasileira de Geografia, v. 17, n. 1, p. 1-48, 1955.

ALMEIDA, F. F. M.; HASUI, Y.; PONÇANO, W. L.; DANTAS, A. S. L.; CARNEIRO, C. D. R.; MELO, M. S.; BISTRICHI, C. A. Mapa geológico do Estado de São Paulo: escala 1:500.000. São Paulo: IPT, 1981. 124p. (Monografia 6).

ANDRADE, A. T. L. Análise dos processos hidrodinâmicos e sedimentares da enseada da Fortaleza, Ubatuba/São Paulo. 2002. 87 f. Dissertação (Mestrado) Instituto Oceanográfico, Universidade de São Paulo.

BARROS, M.O. DE \& TESSLER, M.G. Profile changes on Fazenda, Puruba and Itamambuca beaches, Ubatuba on the northern coast of São Paulo state, Brazil, as related to meteorological conditions. Journal of Coastal Research, V. 35, p. 184-183. 2003.

BENAVENTE, J.; DEL RIO, L.; ANFUSO, G.; GRACIA, F.; REYES, J. Utility of Morphodynamic Characterisation in the Prediction of Beach Damage by Storms. Journal of Coastal Research, n. 36, p. 56- 64, 2002. Special issue.

BITTENCOURT, A. C. S. P.; FARIAS, F. F.; ZANINI JR, A. Reflexo das variações morfodinâmicas praiais nas características texturais dos sedimentos da praia da Armação, Salvador, Bahia. Revista Brasileira de Geociências, São Paulo, v. 17, n. 3, p. 276-282, 1987. 
BRYANT, E. A. Storminess and high tide beach change, Stanwell Park, Australia 19431978. Marine Geology, v. 79, p. 171-187, 1987.

BRYANT, E. A. Natural Hazards. Melbourne: Cambridge University Press, 1991. 294

p.

CAlliari, J. L Estudo da Ciclogênese e Anticiclogênese no Sul e Sudeste do

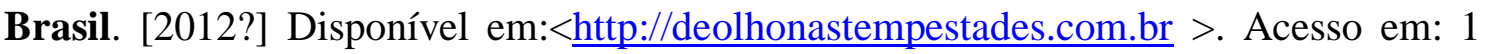
abr. 2012.

CALLIARI, L. J.; TOZZI H. M.; KLEIN, A. H. F. Respostas das praias entre Rio Grande e Chuí a passagem de sistemas frontais de alta energia, RS. In: SEMANA NACIONAL DE OCEANOGRAFIA, 7., 1994. Resumos... Itajai: Univali, 1994.

CAPO, S.; PARISOT, J. P.; BUJAN, S.; SÉNÉCHAL, N. Short time morphodinamics responses of Truc Vert Beach to storm condition. Journal of Coastal Research, n. 56, p. 10, 2009. Special issue.

CARTER, R. W. G.; BALSILliE, J. H. A note on the amount of wave energy transmitted over nearshore sand bars. Earth Surface Processes Landforms, v. 8, p. 213-222, 1983.

CASTRO-FILHO, B. M.; MIRANDA L. B.; MIYAO, S. Y. Condições hidrográficas na Plataforma continental ao Largo de Ubatuba: variações sazonais e media Escala los.

Boletim do Instituto Oceanográfico, São Paulo, v. 35, n. 2, p. 135-151, 1987 
CAZZOLI Y GOYA, S. Dinâmica sedimentar atual das praias de Cibratel e Itanhaém-Suarão, município de Itanhaém, estado de São Paulo. 1997. 163 f. Dissertação (Mestrado)-Universidade de São Paulo.

DAIL, H. J.; MERRIFIELD, M. A.; BEVIS, M. Steep beach morphology changes due to energetic wave forcing. Marine Geology, v. 162, n. 2-4, p. 443-458, 2000.

FARIAS, F. F.; BITTENCOURT, A. C. S. P.; ZANINI JR, A.; DOMINGUEZ, J. M. L. Variações temporais e espaciais na dinâmica de sedimentação da praia da Armação Salvador/BA. Revista Brasileira de Geociências, São Paulo, v. 15, n. 1, p. 48-54, 1985.

FREITAS, M. P.; MENEZES, J. T.; LANGUI, M. P.; VINTÉM, G.; KLEIN, A. H. F. Morphological analysis of beach through global system position. Journal of Coastal Research, n. 39, p. 669-672, 2006. Special issue.

FÚlFARO, V. J.; SUGUIO, K.; PONÇANO, W. L. A gênese das planícies costeiras paulistas. 1974. In : CONGRESSO BRASILEIRO DE GEOLOGIA, 28.,Porto Alegre. Anais... Porto Alegre: SBG, 1974. v. 3, p. 37-42.

GILI, J. A.; COROMINAS, J.; RUS, J. Using Global Position System techniques in landslide monitoring. 2000. Engineering Geology, v. 55, n. 3, p. 167-192, 2000.

HOEFEL, F. G. Morfodinâmica de praias arenosas oceânicas: uma revisão bibliográfica. Itajaí: UNIVALI, 1998. 93 p. 
SILVA, M. G. A. J.; DIAS, M. A. F. S. A frequência de fenômenos meteorológicos na América do Sul: uma climatologia. In: CONGRESSO BRASILEIRO DE METEOROLOGIA, 12., 2002, Foz do Iguaçu. Anais... :SBMET., 2002.

KLEIN, A. H. F.; MENEZES, J. T. Beach morphodynamics and profile sequence for a headland bay coast. Journal of Coastal Research, v. 17, n. 4, p. 812-835, 2001.

KLEIN, A. H. F.; BENEDET FILHO, L.; SCHUMACHER, D. Short-term beach rotation processes in distinct headland bay beach systems. 2002. Journal of Coastal Research, v. 18, n. 3, p. 442-458, 2002

KLEIN, A. H. F.; POLETTE, M.; HOEFEL, F.; DIEHL, F. L.; CARVALHO, J. L. B.; SILVA, R. P.; SIEGLE, E.; ABREU, J. G. N.; SANTOS, M. I. F.; FACHIN, S. Erosão costeira no litoral centro-norte de Santa Catarina: possíveis causas e medidas mitigadoras. In: CONGRESSO DA ASSOCIAÇÃO BRASILEIRA DE ESTUDOS DO QUATERnÁRIO, 7., 1999, Porto Seguro. O Quaternário e o meio ambiente. [S.1.]: ABEQUA, 1999. CD-ROM.

KLEIN, A. H. F.; TEMME, B.; CARVALHO, J. L. B.; JABOR, P. M.; DIEHL, F. L. Comportamento morfológico de uma praia semi-protegida: Praia de Balneário Camboriú, Santa Catarina. In: SEMINÁRIO SOBRE ONDAS E MARÉS, 2., 1997, Arraial do Cabo. Resumos... Arraial do Cabo: Instituto de Estudos do Mar Almirante Paulo Moreira, 1997. 
KLEIN, A. H. F.; MENEZES, J. T. Coastal erosion vulnerability analysis methodology. Journal of Coastal Research, v. 39, p. 1811-1813, 2006.

NASCIMENTO, K. C. Monitoramento por DGPS e Análise de Processos Erosivos da Linha de Costa na Praia de Pirangi do Norte - Parnamirim / RN. 2009. 112 f. Dissertação (Mestrado) - Universidade Federal do Rio Grande

KOWSMANN, R. Variações de curto e longo prazo de um perfil da Praia de Copacabana, Rio de Janeiro. Rio de Janeiro: Instituto de Pesquisas da Marinha, 1970.

LUCA, C. B de . Implementación de herramientas numéricas y bases de datos en el SMC-Brasil y su aplicación en el caso piloto de la playa de Massaguaçu-Brasil. 2011. 201 f. Dissertação (Mestrado). Universidad de Cantabria.

MAHIQUES, M. M. Variações temporais na sedimentação quaternária dos embaiamentos da região de Ubatuba, estado de São Paulo. 1992. 2 v. Tese (Doutorado) - Instituto Oceanográfico, Universidade de São Paulo.

MARTINS, C. C. Variações morfológicas e sedimentares de curto período em perfis praias, Praia da Bertioga/SP. 161 f. 2000. Dissertação (Mestrado) - Instituto Oceanográfico, Universidade de São Paulo.

MARTINS, C. C. Morfodinâmica de praia refletiva estudo de caso na praia da Sununga, litoral norte do Estado de São Paulo. 209 f. 2006. Tese (Doutorado) Instituto Oceanográfico. Universidade de São Paulo. 
MASSELINK, G.; PATTIARATCHI, C. The effect of sea breeze on beach morphology, surfe zone hydrodynamics and sediment resuspension. Marine Geology, v. 14, p. 393-406, 1998.

MASSELINK, G.; SHORT, A. D. The effect of tide range on beach morphodynamics and morphology: a conceptual beach model. Journal of Costal Research, v. 9, n. 3, p. 785-800, 1993.

MAZZINI, P. L. F.; SCHETTINI, C. A. F. Evaluation of spatial interpolation methodologies applied to quasisynoptic coastal hidrographic data. Brazilian Journal of Aquatic Science \& Technology, v. 13, n. 1, p. 53-64, 2009.

MUEHE, D. Aspectos gerais da erosão costeira no Brasil. Mercator, v. 4, n. 7, p. 97$110,2005$.

MUEHE, D. Geomorfologia Costeira. In: GUERRA, A. J. T.; CUNHA, S. B. (Org.). Geomorfologia: uma atualização de bases e conceitos. 9. ed. Rio de Janeiro -(RJ).1996. Rio de Janeiro: Bertrand Brasil, 2009. cap. 6.

NIMER, E. Climatologia do Brasil. 2 ed. Rio de Janeiro: Fundação Instituto Brasileiro de Geografia e Estatística, 1989.

OLIVEIRA, J.; LOPES, C. P.; BRAGA, S. E.; CHIOZZINI, G. V. Estudo da variação sazonal das concentrações de 222Rn em amostras de água do mar nas enseadas de 
Ubatuba, para a estimativa da descarga de águas subterrâneas. In: INTERNATIONAL NUCLEAR ATLANTIC CONFERENCE, 2005, Santos. INAC 2005 . S.1.: s.n., 2005. 1 CD-ROM.

PONÇANO, W. L.; TESSLER, M. G.; FREITAS, C. G. L. MAHIQUES, M. M. Tendências regionais de transporte se sedimentos arenosos ao longo das praias paulistanas. Geociências, v. 6, p. 102-115, 1999.

PUGH, D. T. Tides, surges and mean sea level. Chichester: Jonh Wiley \& Sons, 1986. $472 \mathrm{p}$.

ROCHA R. P.; SUGAHARA, S. SILVEIRA, R. B. Sea waves generated by extratropical cyclones in the South Atlantic Ocean: hindcast and validation against altimeter data. Weather and Forecasting, v. 19, n. 2, p. 398-410, 2004.

ROSMAN, P. C. C.; VALENTINI, E. Recent erosion in the stable Ipanema-Leblon beach in Rio de Janeiro. 1989. In: Coastlines of Brazil. New York: ASCE EDTS, 1989. p. 278-291.

SALLENGER, A. H. Storm impact scale for barrier islands. Journal of Coastal Research, v. 16, p. 890-895, 2000.

SHORT, A. D.; TREMBANIS, A. C.; TURNER, I. L. Beach oscillation, rotation, and the Southern Oscilation, Narraben Beach, Australia. INTERNATIONAL CONFERENCE ON COASTAL ENGINEERING, 27., 2000, Sydney. Proceedings... Reston: American Society of Civil Engineers, 2001. p - 2439-2452. 
SHORT, A. D. Three dimensional beach-stage model. Journal of Geology, v. 87, p. 553-571, 1979.

SUGAHARA, S. Variação Anual da Frequência de Ciclones no Atlântico Sul. 2000. In: CONGRESSO BRASILEIRO DE METEOROLOGIA, 11., 2000, Rio de Janeiro. Resumos... Rio de Janeiro : SBMET, 2000. v. 1, p. 2607-2611.

SUGUIO, K. Dicionário de Geologia Marinha. São Paulo: T. A. Queiroz, 1992. 171 p.

SUGUIO, K.; MARTIN, L. Formações quaternárias marinhas do litoral paulista e sul fluminense Quaternary marine formations of the State of São Paulo and southern Rio de Janeiro). In: INTERNATIONAL SYMPOSIUM ON COASTAL EVOLUTION IN THE QUATERnARY, 1978, São Paulo. Proceedings... São Paulo: Instituto de Geociencias, 1979. v. 1, p. 1-55. 